Portland State University

PDXScholar

1983

\title{
Formation and zonation of ferruginous bauxite deposits of the Chapman quadrangle, Oregon
}

Richard Charles Marty

Portland State University

Follow this and additional works at: https://pdxscholar.library.pdx.edu/open_access_etds

Part of the Geology Commons

Let us know how access to this document benefits you.

\section{Recommended Citation}

Marty, Richard Charles, "Formation and zonation of ferruginous bauxite deposits of the Chapman quadrangle, Oregon" (1983). Dissertations and Theses. Paper 3513.

https://doi.org/10.15760/etd.5397

This Thesis is brought to you for free and open access. It has been accepted for inclusion in Dissertations and Theses by an authorized administrator of PDXScholar. Please contact us if we can make this document more accessible: pdxscholar@pdx.edu. 
AN ABSTRACT OF THE THESIS OF Richard Charles Marty

for the Master of Science in Geology presented January 14,1983 .

Title: Formation and zonation of Ferruginous Bauxite Deposits in the Chapman Quadrangle, Oregon. APPROVED BY MEMBERS OF THE THESIS COMMITTEE:

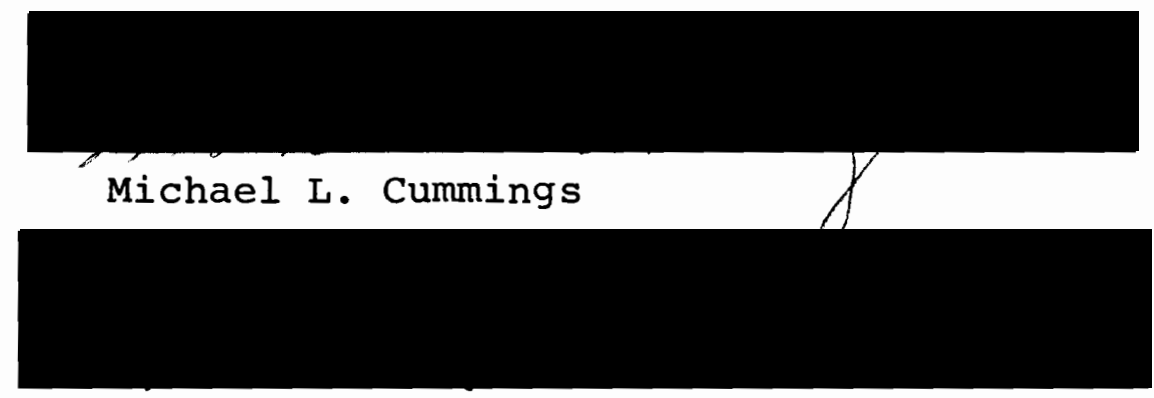

Robert 0. Van Atta

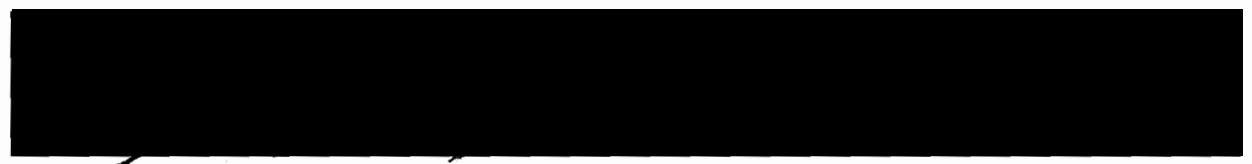

Marvin $\mathrm{H}$. Beeson

Two major theories have been advanced to account for the scattered distribution of ferruginous bauxite deposits. Original workers proposed that ferruginous bauxite originally developed over all exposed Columbia River Basalt in western Oregon and was subsequently removed by erosion. Studies which followed have suggested that it may be locally favorable conditions, especially of drainage, which are responsible for deposit distri- 
bution. Field mapping in the Chapman Quadrangle shows a possible correlation between a series of sheared zones, which may have improved drainage, and the distribution of ferruginous bauxite deposits. Examination of the pisolitic zone ferruginous bauxite of the Chapman Quadrangle failed to show any evidence supporting the theory that this zone was produced by fluvial action. It appears, instead that the pisolitic zone of the deposits studied developed in place and that the structures seen in this zone are the result of authigenic processes. Mineralogical study of samples from the Chapman Quadrangle suggests that the ferruginous bauxite of the area probably developed under slightly acidic $\mathrm{pH}$ conditions and that the assemblage quartz, kaolinite, gibbsite may exist in ferruginous bauxite deposits because of the presence of iron oxide and hydroxide coatings on the quartz which may cut off contact between quartz and gibbsite. Chemical study shows that the lateral variation in elemental concentrations is much less than the vertical variation in concentrations seen by some previous workers, and that lateral variation appears to be randomly distributed for most elements. The behavior of elements during weathering can best be modeled by taking into account the various sorbtive reactions between ions formed during weathering and clays and hydroxides. 


\section{FORMATION AND ZONATION OF FERRUGINOUS BAUXITE DEPOSITS OF THE CHAPMAN QUADRANGLE, OREGON}

by

RICHARD CHARLES MARTY

A thesis submitted in partial fulfillment of the requirements for the degree of

MASTER OF SCIENCE

in

GEOLOGY

Portland State University

1983 


\section{TO THE OFFICE OF GRADUATE STUDIES AND RESEARCH:}

The members of the Committee approve the thesis

of Richard Charles Marty presented January 14, 1983.
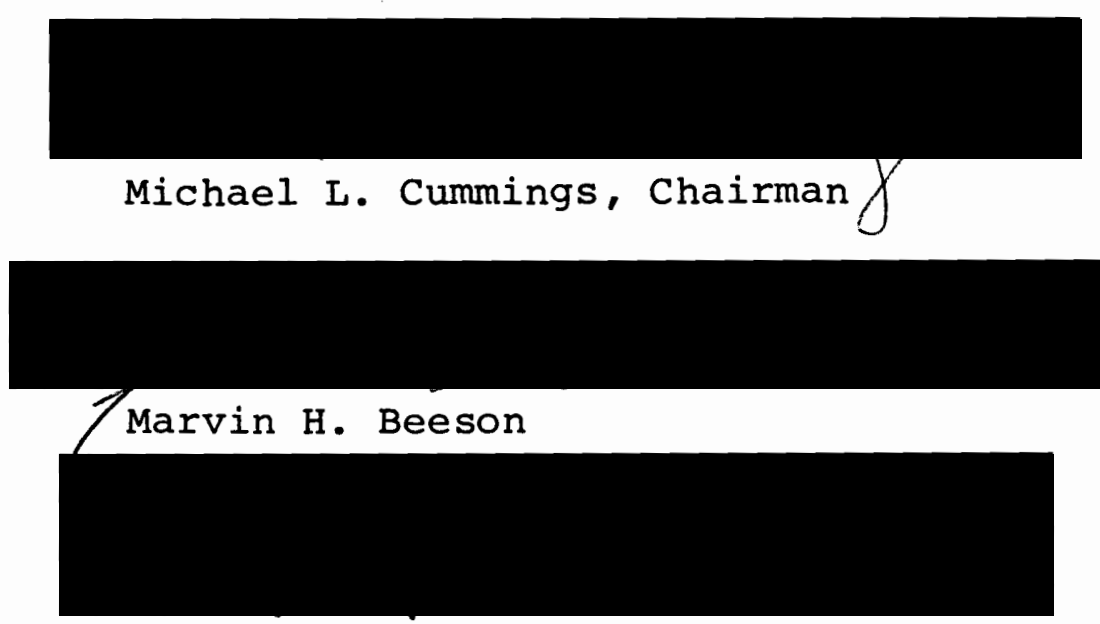

Robert 0. Van Atta

APP ROVED :

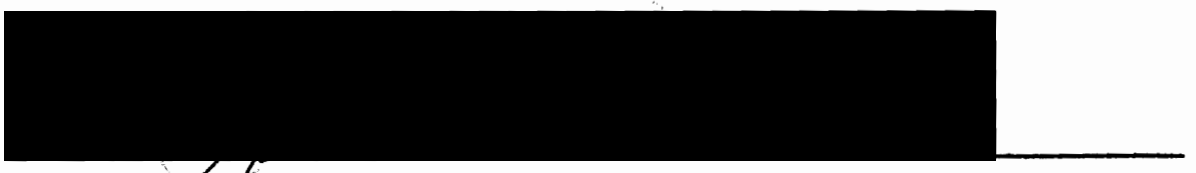

Gilbert T. Benson, Head, Department of Geology

Stanley E. Rauch, Dean of Graduate Studies and Research 


\section{ACKNOWLEDGEMENTS}

Partial support for this study was provided by the William and Edith Rockie Scholarship Fund of the Portland State University Earth Science Department and by Sigma Xi. This support is gratefully acknowledged. Thanks are due to Dr. Robert Van Atta, Dr. Michael Cummings and Dr. Marvin Beeson for suggesting improvements in the final product. I would also like to thank my parents for their support during all the years it took to prepare this document. 
TABLE OF CONTENTS

PAGE

ACKNOWLEDGEMENTS.........................

LIST OF TABLES.........................

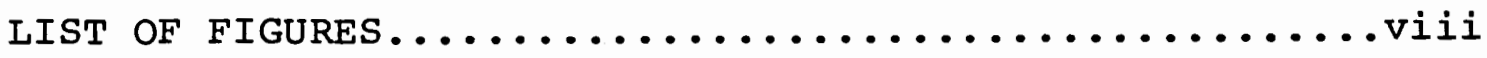

CHAPTER

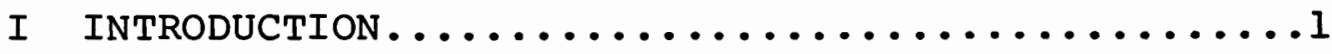

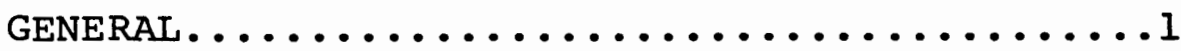

PURPOSE, SCOPE AND METHODS.............

PREVIOUS WORK ON NORTHWEST FERRUGINOUS

BAUXITE.....................

THE STUDY AREA.......................

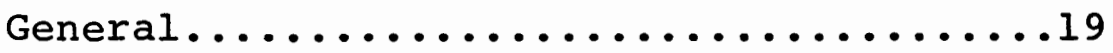

Geologic setting....................

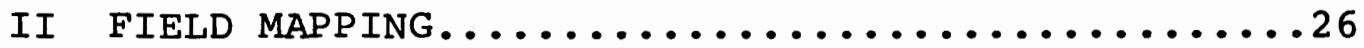

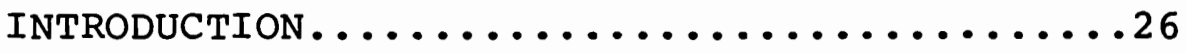

STRATIGRAPHY OF BEDROCK UNITS..........26

SOIL UNITS......................... 33

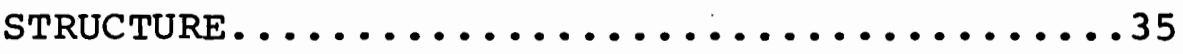

FERRUGINOUS BAUXITE DEVELOPMENT......... 36

III PISOLITIC ZONE FERRUGINOUS BAUXITE........42

INTRODUCTION...................42

DATA AND DISCUSSION..............47

CONCLUSIONS....................... 49 


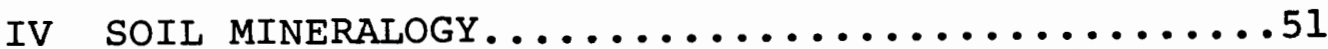

INTRODUCTION. ....................

EXPERIMENTAL METHOD.................

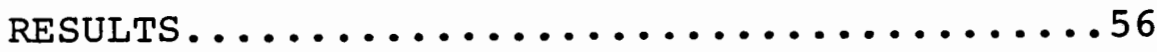

INTERPRETATION AND CONCLUSIONS........58

V GEOCHEMISTRY OF WEATHERING............65

INTRODUCTION....................... 65

EXPERIMENTAL METHOD..............66

STATISTICAL STUDY OF ELEMENTAL BEHAVIOR

DURING WEATHERING.............67

Purpose.................67

Discussion.................68

Runs About the Mean.............77

Summary..................... 80

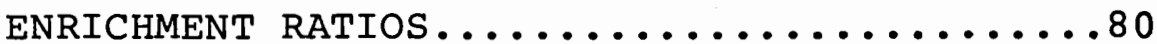

CHEMISTRY OF PISOLITES..............87

FRACTIONATION OF LANTHANIDE ELEMENTS

DURING WEATHERING.............91

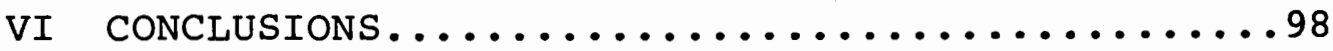

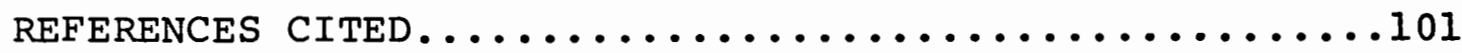

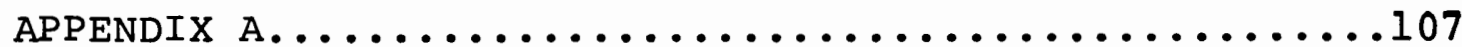

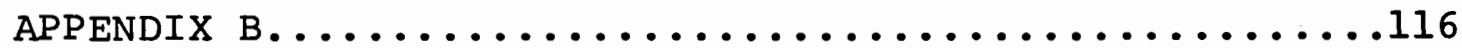




\section{LIST OF TABLES}

TABLE

PAGE

I Average Values for Elements Detected

in Basalt Units from the Study Area........31

II X-ray Peaks Used to Identify Clay Minerals....53

III Minerals Found in Samples from the

Chapman Quadrangle...................... 57

IV Sample One-Tailed Test for Significant

Differences in Elemental Concentrations....69

$\mathrm{V}$ High and Low Values for Concentrations

Determined in Initial Experiment on

Samples $27-4 N-1$ to $10 \ldots \ldots \ldots \ldots \ldots \ldots \ldots$

VI Total Variance, Variance Among Samples,

Variance within Replications and Values

for the $F$ Test Statistic for Elements

Detected in Samples $27-4 \mathrm{~N}-1$ to $10 \ldots \ldots \ldots .73$

VII Mean Concentrations of 23 Elements

Detected in Soils from the Chapman

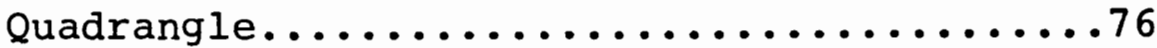

VIII Test of Runs About the Mean...............79

IX Enrichment Ratios for Weathered Materials.....84 
$\mathrm{X}$ Concentrations and Enrichment Ratios of

Lanthanide Group Elements in Weathered

Samples from the Salem Hills............92

XI Energies Used to Determine Elemental

Concentrations Using INAA..............111

XII Elemental Concentrations Determined Using

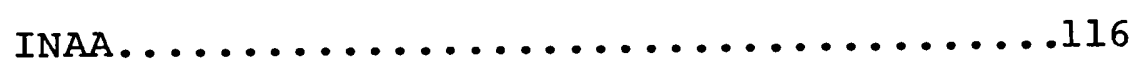




\section{IIST OF FIGURES}

FIGURE

PAGE

1. Location and distribution of ferruginous

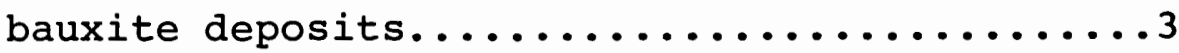

2. Idealized stratigraphic column for sample pits

from Columbia County................4

3. Diagram of relative stratigraphic relation-

ships among Columbia River Basalt flows

found in the Salem Hills area...........16

4. Bedrock geology of the Chapman 7.5'

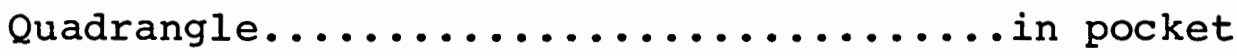

5. Soils of the Chapman $7.5^{\prime}$ Quadrangle....... in pocket

6. Stratigraphic column showing bedrock units

present in the study area.............27

7. Concentrations of selected elements detected

in basalt samples from the study area.......30

8. Photograph of a fault and overlying ferr-

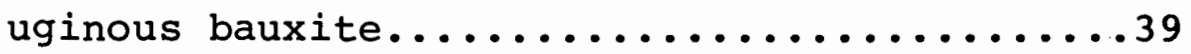

9. Photomicrograph of a clay-rich pisolite under

plane polarized light...............44

10. High-iron pisolite and angular quartz

inclusions shown under plane polarized

light........................... 
11. High-iron pisolite under plane polarized

light showing clear quartz inclusions

in the dark mass of the pisolite.........46

12. Composite $x$-ray diffractograms for a typical

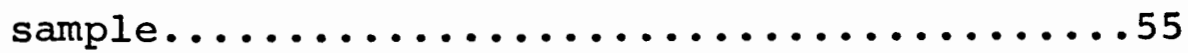

13. Conditions under which each of the major

groups of clays form...............60

14. Solubility of alumium and silica at a pH of $6 \ldots 62$

15. The system $\mathrm{AlOOH}, \mathrm{Fe}_{2} \mathrm{O}_{3}, \mathrm{SiO}_{2}$ at $25^{\circ} \mathrm{C}$ and 1

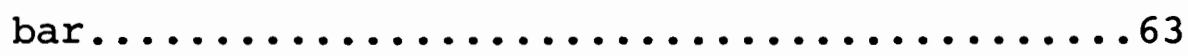

16. Formulae for the computation of the sum of the squares within replications, the sum of the squares among samples and the total sum of squares...........................

17. Cation size versus ionic charge...........82

18. Matrix of competing reactions involving aqua, hydroxide and other ligand (X) complexes in solution and sorbed onto a surface......88 


\section{CHAPTER I \\ INTRODUCTION}

\section{GENERAL}

Laterites are formed by chemical weathering of rocks in which mobile elements are removed by concentrating less soluble elements. Laterites are usually high in iron and aluminum, but they may also contain economically exploitable concentrations of nickel and cobalt (Corcoran and Libbey, 1956, Hotz, 1964, Ziessink, 1971). Most laterites vary from relatively pure iron-rich types to more aluminous varieties which may contain enough aluminum to form bauxite deposits. Laterites are rarely mined for their iron content, but the aluminum in bauxites is the only major source yet exploited for this crucial metal. The term ferruginous bauxite was coined by Libbey and others (1945) to describe deposits high in both iron and aluminum which occur in western oregon and Washington. Similar deposits have since been found at other locations (Patterson, 1971). Hook (1976) and Jackson (1971, 1974) arbitrarily set a 10 percent free silica limit on the term 'ore grade' ferruginous bauxite. Since none of the ferruginous bauxite in oregon or Washington has been shown to be economically exploitable, the term ore is 
not used in this paper.

Figure 1 shows the areal distribution and location of the major ferruginous bauxite deposits of western Oregon and Washington. Ferruginous bauxite occurs as irregularly distributed deposits which overlie flows of the Columbia River Basalt Group (CRB Group). In many places, however, rocks of the CRB Group occur without an overlying layer of ferruginous bauxite. There are two basic theories proposed by previous authors to account for the patchy distribution of ferruginous bauxite deposits. The first theory (Libbey and others, 1945) is that all CRB Group exposures in western Oregon were at one time covered with a blanket of ferruginous bauxite. Areas presently devoid of bauxite have had the ferruginous bauxite which was originally present removed by erosion. This is the 'blanket' theory for ferruginous bauxite formation. The second hypothesis is that the ferruginous bauxite deposits were locally developed in response to some variable such as microclimate, drainage (Hook, 1976) or parent rock composition (Hoffman, 1981) which was for some reason different in the areas where ferruginous bauxite developed.

An idealized stratigraphic sequence for Columbia County ferruginous bauxite deposits is shown in Figure 2. The lowermost zone is one of relatively unweathered basalt 


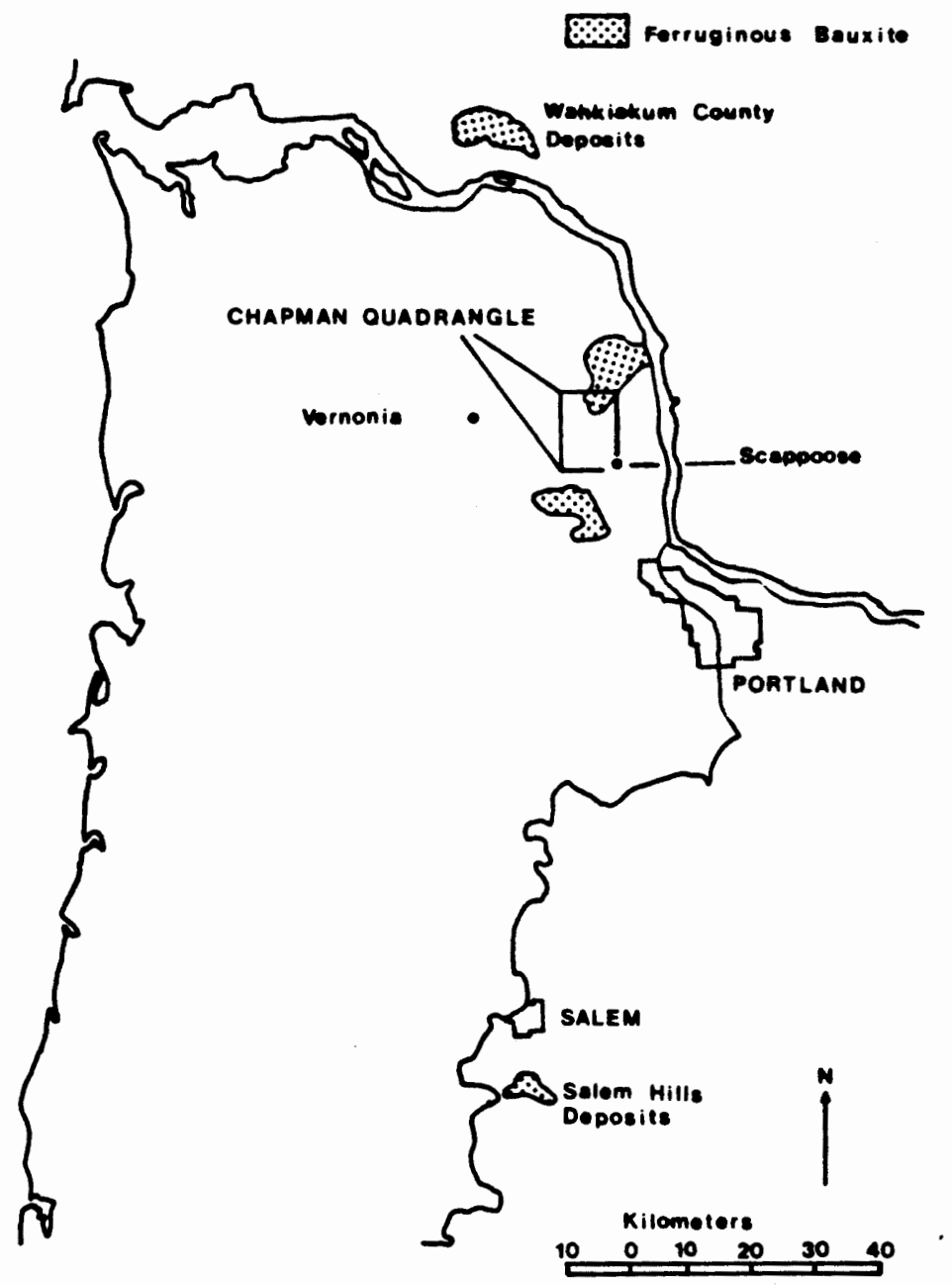

Figure 1. Location and distribution of ferruginous bauxite deposits. After Hook (1976). 


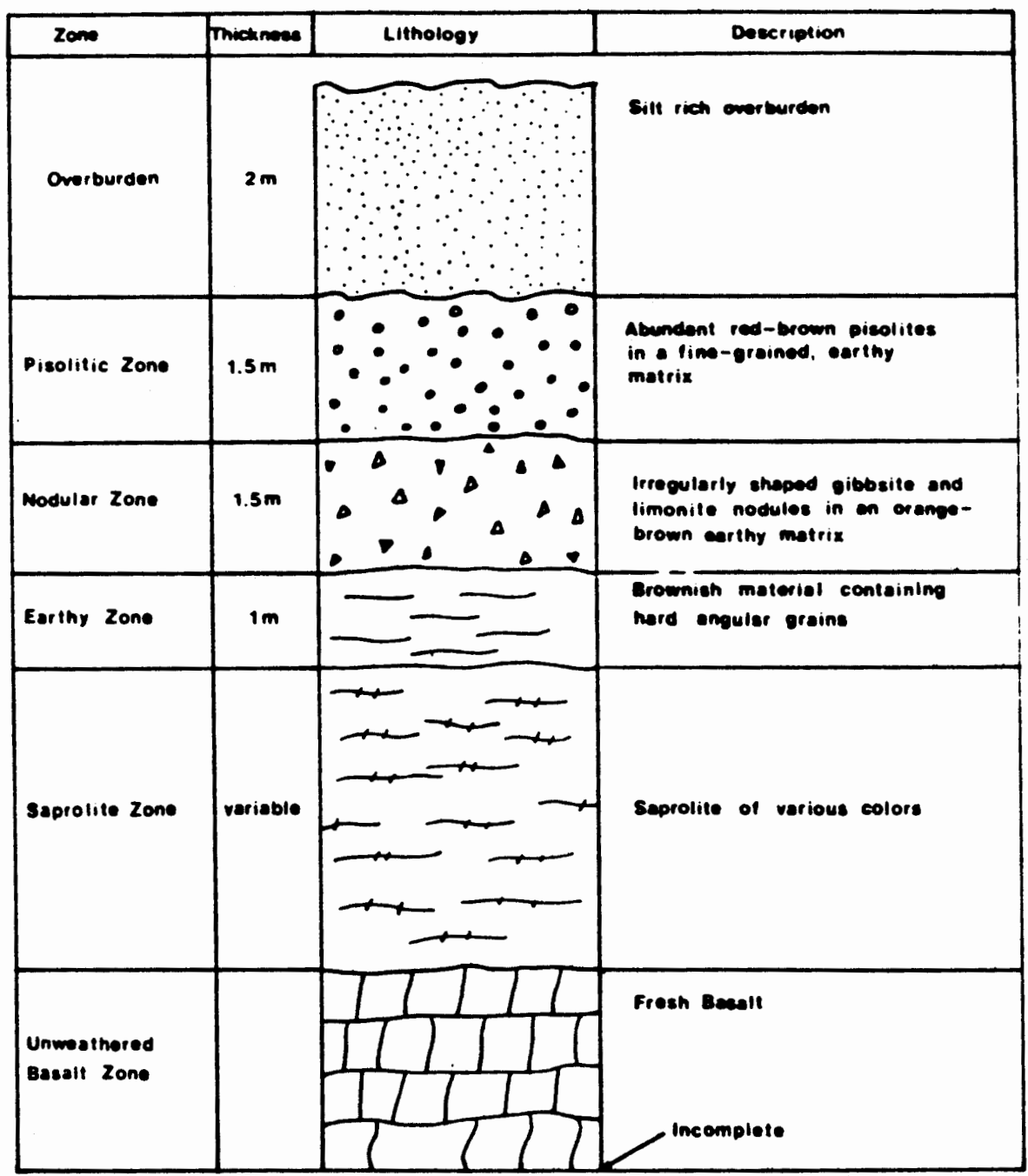

Figure 2: Idealized stratigraphic column for sample pits from Columbia County. Modified from Jackson (1971). 
which is overlain successively by a saprolite zone, an earthy zone, a nodular zone and an upper pisolitic zone. The uppermost zone of ferruginous bauxite may be overlain by various materials depending on the locality. Not all of the above-mentioned zones are found in all ferruginous bauxite deposits. The pisolitic zone, for example, is not found in ferruginous bauxite deposits in the salem Hills of Marion County, Oregon (Corcoran and Libbey, 1956). Also the zones, where present, may not always lie in this order. Wilkinson and others (1946) state that the pisolitic zone of Columbia County ferruginous bauxite deposits may be underlain by either an earthy zone or a nodular zone. The zones of a ferruginous bauxite deposit grade into one another, but may be distinguished in drill cores.

The zonation seen in ferruginous bauxite deposits is roughly similar to zonation sequences seen in other laterite deposits. Relatively unweathered rock is generally overlain by a zone of slightly weathered material, then by a layer of saprolite and finally by completely weathered materials (Gordon and others, 1958, Grubb, 1979, Patterson, 1971). The characteristics of these zones may change, but their general nature is quite similar from one deposit to the next.

The uppermost zone of Columbia county ferruginous 
bauxite deposits is invariably pisolitic (Libbey and others, 1945, Wilkinson and others, 1946, Jackson, 1974). Pisolites are of various types, and include clayrich varieties, gibbsitic varieties and limonitic (highiron varieties (Libbey and others, 1945, Livingston, 1966). High-iron pisolites appear to be the most common type in surface outcrops in Columbia county. The pisolitic ferruginous bauxite typically grades downward into the nodular zone. The nodular zone contains two types of nodules, one of which is gibbsitic and the other limonitic, in a matrix of orange to brown ferruginous bauxite (Jackson, 1971). The gibbsite nodules are pink or gray, normally quite angular and rarely more than $5 \mathrm{~cm}$ in longest dimension (Jackson, 1971). The limonitic nodules are commonly of similar size, but tend to be shades of brown and orange. The underlying zone of fine-grained, brown earthy ferruginous bauxite with its hard, angular grains of iron and aluminum oxides and hydroxides is typically lower in $\mathrm{SiO}_{2}$ than either of the overlying zones, but it has a strong petrographic resemblance to the matrices of the overlying zones (Jackson, 1971).

The ferruginous bauxite grades downward into saprolite. The saprolite zone is highly weathered but still preserves some of the original basaltic structures and textures. The saprolite zone may contain spheroidally weathered corestones of fresh basalt in a matrix of 
highly weathered material, but more commonly the saprolite is a light tan material with flecks of orange showing the original distribution of the mafic minerals. The orange flecks form about the original mafic minerals, but they do not represent true pseudomorphs after the original minerals. The saprolite is usually progressively less weathered lower in the section, and a fresh basalt zone is distinguished by unweathered to slightly weathered rock. Fractures in the fresh basalt zone are often filled with clays and other weathering products produced higher in the section.

During the late 1940's and the early 1950's there was considerable interest in the possible economic and strategic importance of ferruginous bauxite deposits. Chemical properties of the ferruginous bauxites such as its high iron content make it unsuitable for use in American aluminum reduction plants which use the Bayer process, however. The Bayer process requires an aluminum plant to use ore with a low iron concentration. Plants could be built to refine and reduce ferruginous bauxite, but this is not presently economical. Reynolds Metals retains control of the mineral rights to the ferruginous bauxite deposits in most of oregon and Washington, but a breakthrough in technology or an interruption in the supply of foreign bauxite will be necessary if it is 
ever to become economically feasible to strip mine the ferruginous bauxite.

\section{PURPOSE, SCOPE AND METHODS}

Ferruginous bauxite deposits are representative of a large class of deposits which contains economically important members, and the answers to questions about ferruginous bauxite deposits may have application towards understanding all lateritic deposits. This work is oriented toward a closely defined and fairly narrow set of problems. The first problem addressed concerns the patchy distribution of ferruginous bauxite deposits. C.W. Hoffman (1981) found that ferruginous bauxite deposits are associated with a flow of Frenchman springs Basalt originally believed to be the Kelley Hollow flow in the Salem Hills area. The first phase of this work checked to see if this correlation is present in the Chapman Quadrangle. Bedrock units in the Chapman Quadrangle were mapped and their distribution was compared to the mapped extent of ferruginous bauxite deposits.

The second problem addressed concerned the origin of the pisolitic zone commonly found in ferruginous bauxite deposits. Jackson (1974) proposed that the pisolitic zone formed as a result of aqueous reworking of pre-existing ferruginous bauxite, and not as a result 
of in situ weathering. This hypothesis was tested using a variety of methods including: study of individual pisolites, observations at numerous outcrops of pisolitic ferruginous bauxite in the study area and petrographic examination of inclusions found in the pisolites.

The third problem was an attempt to establish the conditions under which ferruginous bauxite deposits formed. X-ray diffraction was employed to determine the mineral content of ferruginous bauxite, saprolite, sediment and weathered sediment samples from the study area, and instrumental neutron activation analysis (INAA) was used to determine trace element concentrations in various samples of ferruginous bauxite, saprolite and fresh basalt. Mineral content of the ferruginous bauxite together with chemistry provided a great deal of information on the problem. Review of previous work concerning bauxite, ferruginous bauxite and other laterite deposits was incorporated throughout the work for comparative purposes.

PREVIOUS WORK ON NORTHWEST FERRUGINOUS BAUXITE

Most of the early work on ferruginous bauxite was performed by geologists of the Oregon Department of Geology and Mineral Industries. The most complete summary of their early work was published in 1945 
(Libbey and others, 1945). Libbey studied the extent and purity of the ferruginous bauxite deposits, but also proposed the first model for the development of ferruginous bauxite profiles. Ferruginous bauxite deposits appeared to be correlated with topographic highs, suggesting that ferruginous bauxite deposits may have been more widespread at one time, perhaps developing over all exposed CRB before removal by subsequent erosion. Erosion during uplift removed material from the developing valleys and left the ferruginous bauxite only on the hills.

Libbey and others (1945) also examined the pisolites of the pisolitic zone. The iron to aluminum ratio is higher in the pisolites than in the matrix which surrounds them. Libbey proposed that this was due to possible concentration of iron due to 'immobile fractionation', but did not present an opinion on whether the inclusions formed as a result of weathering or from sedimentary processes. Libbey also suggested that laterization is a slow process and required a period of tectonic stability during the Mio-Pliocene, the time during which the deposits were believed to have formed. Much of Libbey's work was later republished (Libbey and others, 1946).

V.T. Allen (1948) made the next significant 
contribution to the ferruginous bauxite story. With the aid of thin sections and clay analyses, Allen proposed that the production of bauxite was through a two-stage process of weathering. The basalt first degenerates to a collection of clays, and then the clays undergo further weathering and concomittant leaching of silica to produce ferruginous bauxite. In the first stage of alteration, plagioclase feldspar weathers to kaolinite and the accompanying mafic minerals, mainly augite, react to form nontronite. Subsequent weathering removes more silica and the kaolinite and nontronite react to form gibbsite and iron-rich bauxite.

Corcoran and Libbey (1956) investigated the geochemistry of drill cores from ferruginous bauxite deposits in the Salem Hills area, Marion County, Oregon. Corcoran and Libbey found that the clay-rich overburden in this area is often underlain by a zone averaging one meter in thickness of almost pure gibbsite. Corcoran and Libbey also noted an inverse relationship between depth below the surface and iron concentration in the laterite under the gibbsite layer. They attributed this increase in iron concentration to capillary action which transported iron up into the top of the laterite profile. Corcoran and Libbey also noted marked non-systematic variations in the silica content of samples taken at 
0.6 meter depth intervals.

Corcoran and Libbey proposed that processes similar to those proposed by D.G. Sherman (1949) for Hawaiian laterites were acting during the formation of oregon ferruginous bauxite deposits. Sherman noted a correlation between a continuous supply of rainfall and high alumina laterites and between interspersed wet and dry seasons and the formation of ferruginous laterites. He maintained that the alternating wet and dry seasons in a warm climate allowed iron and titanium to become concentrated near the surface by capillary action. Iron is leached as $\mathrm{Fe}^{+2}$ and drawn up into more oxygenated soil where the iron is oxidized to $\mathrm{Fe}^{+3}$. The insoluble $\mathrm{Fe}^{+3}$ is subsequently immobile unless it is reduced or the $\mathrm{pH}$ becomes less than 3 .

Livingston (1966) in a report for the Washington Division of Mines and Geology described the geology of the Kelso-Cathlamet area in southern Washington and reported ferruginous bauxite in Washington, the earliest published report of such deposits. Washington deposits, like those in Columbia County, contain a well developed pisolitic zone. The pisolitic ferruginous bauxite typically contains large pisolites embedded in a matrix of smaller pisolites and fine granular material which is similar to the bauxite found in the earthy zone. 
The pisolites vary in composition. Some are a fairly homogeneous mixture of cliachite, an amorphous mixture of hydrated aluminum oxides, and limonite with scattered grains of gibbsite, while others have a dark, opaque, iron-rich center surrounded by lighter material of uncertain origin and nature (Livingston, 1966).

Livingston suggested that the laterization of the CRB in this area began shortly after it was deposited. This process continued into the Pleistocene, when a thick blanket of loess, probably correlative with the silts found overlying weathered basalts and ferruginous bauxite deposits in the study area, was deposited over the laterites. Livingston also proposed that the laterization process may not have been terminated everywhere and that laterization may be ongoing.

Ronald Jackson $(1971,1974)$ attempted to deal with a variety of problems concerning ferruginous bauxite deposits. His 1971 article in The ore Bin is a report on the 'ore' profiles seen at two prospect pits in Columbia County, Oregon. In an unpublished Portland State University M.S. thesis, Jackson considered the mechanism of bauxite genesis (Jackson, 1974). He examined corestones, boulders of relatively unweathered basalt sometimes found in laterite profiles, which he believed provided a view in miniature of the changes 
which occur during the transition from basalt to ferruginous bauxite. Using data obtained from thin sections, $x$-ray diffraction analysis and instrumental neutron activation analysis, Jackson concluded that the two-step weathering process proposed by V.T. Allen (1948) could not be disproved, and that the pisolitic zone was a result of aqueous reworking of ferruginous bauxite. John Hook (1976) used previously confidential company reports from Alcoa and Reynolds Metals to summarize previous work regarding ferruginous bauxite genesis and distribution. Hook published a map of the distribution, extent and tonnage of the ferruginous bauxite resources of oregon and Washington. This map served as the basis for Figure 1. Hook observed a trend of increasing bauxite grade down valley in the Mill Creek drainage of Wahkiakum County, Washington. Hook believed the Mill Creek drainage to be a relatively recent geomorphic feature, and suggested that laterization has been active in recent times. This differs from the previously held opinion that the bauxite formed during a Miocene to Pliocene warm period (Libbey and others, 1945, Corcoran and Libbey, 1956).

The most recent work on ferruginous bauxite deposits is that of Hoffman (1981). Hoffman studied deposits in the Salem Hills of Marion County, oregon. His main goals 
were the production of a map of the CRB Group flows and the ferruginous bauxite deposits in the Salem Hills area, and investigation of the geochemistry of the ferruginous bauxite. Hoffman found six informally designated CRB Group flows in the Salem Hills area (Figure 3). Two Frenchman Springs flows found in the area were informally correlated with the Kelley Hollow flow and the Ginkgo flow, and arestratigraphically underlain by four flows of older Grande Ronde Basalt of which only the Winter Water flow was correlated to an informally named flow. The identification of flows in this area is not positive or formal, but was useful in the Salem Hills for correlation of local stratigraphy. The identity of the flow of Frenchman Springs Basalt identified by Hoffman and the Kelley Hollow flow, for example, has since been questioned (Beeson, personal communication, 1982). The Grande Ronde Basalt is informally divisible into one flow of high Mgo Grande Ronde Basalt and three flows of older low Mgo Grande Ronde Basalt, one of which is the above-mentioned Winter Water flow, in the Salem Hills area.

No ferruginous bauxite was found overlying the Grande Ronde Basalt in the Salem Hills. Hoffman reported that all ferruginous bauxite in the Salem Hills has developed from the uppermost flow of Frenchman Springs Basalt (Figure 3 ). Other basalt flows are weathered in 


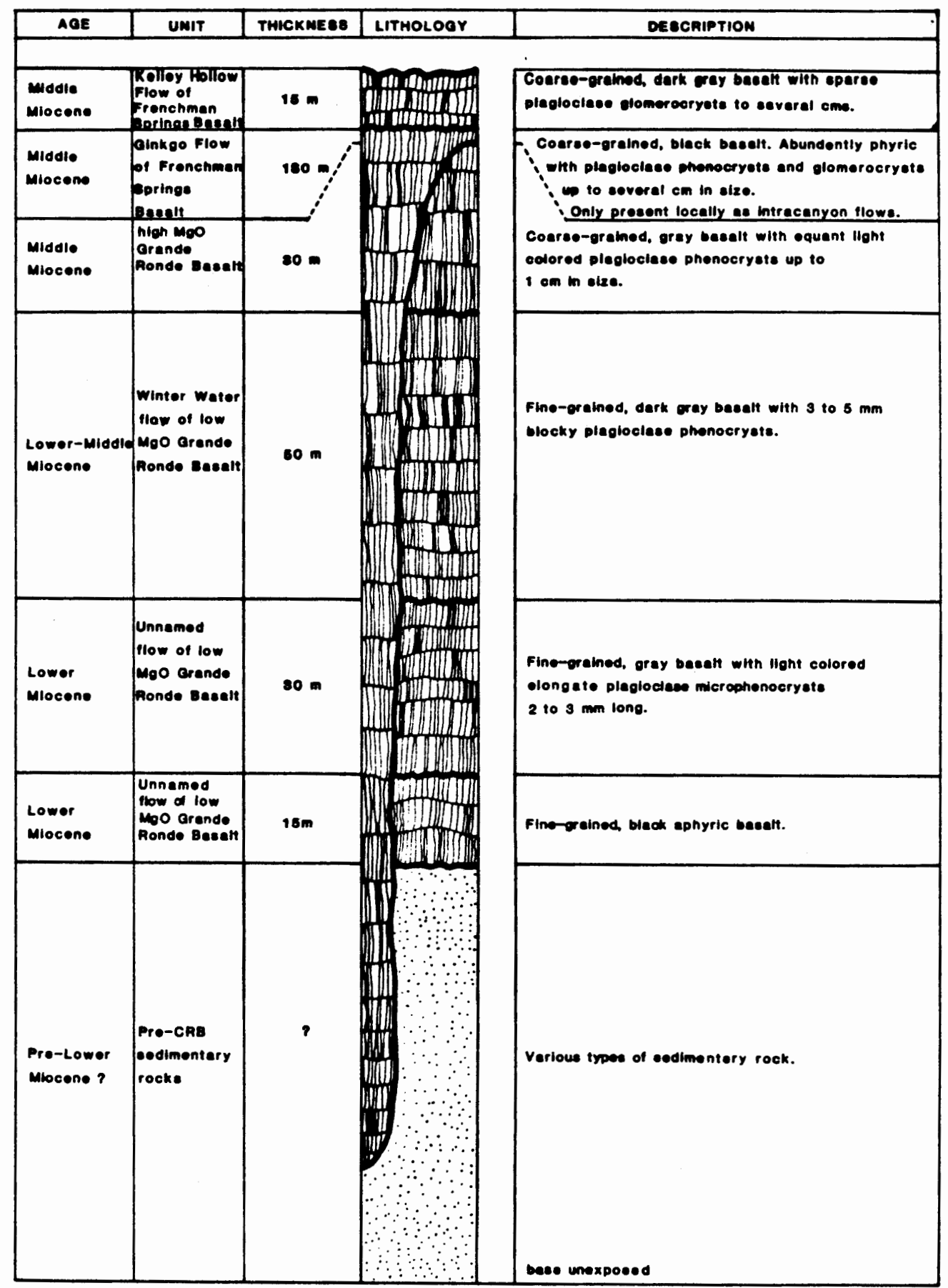

Figure 3. Diagram of relative stratigraphic relationships among Columbia River Basalt flows found in the Salem Hills area. Modified from Hoffman (1981). 
this area, but the weathering did not produce bright red-orange ferruginous bauxite. The correlation between the top flow of Frenchman Springs Basalt and ferruginous bauxite is thought to be due to lateral movement of waters trapped in the flow by an underlying aquaclude of impermeable materials developed during pre-emplacement weathering of underlying basalt flows. The aquaclude also served to protect the underlying basalt from the action of groundwater (Hoffman, 1981, Hoffman and Cummings, 1982).

During the weathering process, ferruginous bauxite profiles have been enriched relative to parent basalt composition in iron, titanium, aluminum and water. Magnesium, sodium, potassium and silica, on the other hand, have been depleted. The degree to which these elements have been enriched or depleted appears to vary considerably over relatively short vertical distances (Corcoran and others, 1956, Hoffman, 1981). Trace element concentrations also appear to vary dramatically over relatively short distances within laterite profiles. Vertical inhomogeneities in the distribution of trace elements within the laterite profile appear to be very much greater than trace element inhomogeneities in the parent basalt flow (Hoffman, 1981). Hoffman (1981) noted that there appeared to be patterns of sympathetic 
behavior between groups of trace elements during weathering. The rare earth elements $\mathrm{La}, \mathrm{Ce}$ and Sm appear to behave similarly as do the groups Sc, Th and $\mathrm{Hf}$ and $\mathrm{Mn}$ and $\mathrm{Co}$. Some of the variability in the behavior of the rare earth elements was believed by Hoffman (1981) to be related to the physical properties of the flow and thus its weathering character. Hoffman followed earlier workers (Allen, 1948, Jackson, 1974) in concluding that a two-step alteration process is probably responsible for the formation of ferruginous bauxite. Allophane, smectite, halloysite and kaolinite are the first formed minerals which subsequently alter to hydrated iron and aluminum oxides. Hoffman also supported Hook's theory that the development of ferruginous bauxite occurs in response to the development of youthful topography. In places within the Salem Hills the ferruginous bauxite appears to drape over the topography in a manner which suggests that the development of the weathered material was influenced by the initial development of the topography. Hoffman, however, favored modification of Hook's theory to reconcile it with observations that some of the original ferruginous bauxite has been removed by erosion (Hoffman, 1981). 


\section{THE STUDY AREA}

\section{General}

The study area is located in the Chapman $7.5^{\prime}$ Quadrangle which includes T4N R2W from the Willamette Meridian and some additional sections in adjacent townships (Figure 1). The population concentrations in this vicinity are a major hindrance to mapping. Most homes have, however, been developed on old farm lands which overlie sedimentary bedrock. The clay-rich nature of the soils developed over basalt makes them unsuitable for farming. This area was chosen for study because previous work (Libbey and others, 1945, Wilkinson and others, 1946) showed it to contain ferruginous bauxite deposits derived from basalt, and this made it possible to test various hypotheses proposed by previous workers. Access to the area is available via U.S. 30 which runs north-south along the edge of the area and by secondary and logging roads which crisscross the area. Almost no point in the area is more than a few kilometers from a passable road during the summer. Access is more difficult during the spring, fall and winter since soil surfaced roads are impassable during the wet season.

Surface and timber rights to much of the area underlain by basalt are held by crown Zellerbach and 
the Longview Fiber Company. The mineral rights to most of the bauxite-bearing areas belong to Reynolds Metals. Most landowners in the area were quite cooperative. The average yearly rainfall in Vernonia (Figure 1) is about $150 \mathrm{~cm}$, and is probably similar to the amount received within the study area. Most precipitation is in the form of rain during the fall, winter and spring. Summers in the coast Range are generally dry. The mean annual temperature of Portland is $12^{\circ} \mathrm{C}$ : the highest mean monthly maximum temperature occurs during July $\left(26^{\circ} \mathrm{C}\right)$; the lowest mean monthly minimum temperature occurs during January $\left(1.1^{\circ} \mathrm{C}\right.$ ) (Summaries of climatological data by sections, 1926). These conditions are undoubtedly similar to conditions in the study area.

The vegetation of the area is typical of the northern Oregon Coast Range. The timber is chiefly second and third growth stands of various species including douglas fir Pseudotsuga mensiesii (Mirbel) Franco and western hemlock Tsuga heterophylla (Raf.) Sarg.. The understory is dominated by salal Gaultheria shallon Pursh, blackberries Rubus spp., vine maple Acer circinatum Pursh and various other species. These species produce an impenetrable thicket and obscure the 'rocks' and weathering products in the area. 
Geologic Setting

The Chapman Quadrangle is located near the boundary of the Willamette Valley and Coast Range physiographic divisions proposed by Dicken (1965). Lower to middle Eocene pillow lavas and breccias are the basement rock in much of the Coast Range of Oregon. These rocks grade from tholeiitic basalts typical of oceanic ridges near the base of the section to alkalic basalt typical of island arc-type terranes at the top of the section (Snavely and others, 1980). Volcanic activity and sedimentation in the island arc terrane produced a thick sequence of intercalcated marine sedimentary and volcanic deposits represented in the vicinity of the Chapman Quadrangle by the Cowlitz Formation and the Goble volcanics respectively.

The oligocene was a time of marine transgression in the northern Coast Range. Shallow water upper Eocene deposits are in many places overlain by Oligocene deposits indicative of much deeper water. Sediments were supplied to this basin from volcanic islands in the area and from the adjacent continent where the ancestral Cascades were shedding considerable volumes of sediment (Baldwin, 1981). It was during this epoch that the sedimentary rocks which underlie the Columbia River Basalt in the study area were presumably deposited. 
The faunal diversity in the paleontologic record decreases markedly from the Eocene to the oligocene, indicating a possible climatological cooling trend for the west coast of North America (Addicott, 1969). Faunal diversity continued to decrease into Miocene time indicating further cooling.

During the Miocene much of northwest Oregon was subaerially exposed as can be seen from the subaerial nature of the CRB found in the study area and other portions of northwest oregon. The earliest CRB Group flows to reach western oregon were those of the low Mgo Grande Ronde geochemical type. These flows were followed successively by the high Mgo Grande Ronde geochemical type and later by flows of the Frenchman springs and Priest Rapids Members of the Wanapum Basalt (Beeson and Moran, 1979).

The widespread continental glaciations of Pleistocene time produced extensive effects in western oregon. There are large deposits of very poorly indurated quartzite pebble-bearing gravels in the study area. These gravels were probably deposited during the Spokane floods (Bretz and others, 1956, Glenn, 1965) and probably do not belong to the Troutdale Formation as mapped by Wilkinson and others (1946). The distinction is not, however, vital to this thesis and the gravels were mapped 
together with other post-CRB gravels and not studied in detail. Extensive deposits of silt which appear to be analogous to the Portland Hills (Lentz, 1977, 1981) silt were also found in the study area. These silt deposits occur as a pervasive blanket in the study area, occuring at elevations up to 400 meters. Previous geologic study of the study area is limited to that produced by Wilkinson and others (1946). Wilkinson and others mapped five units in the study area. From oldest to youngest these units are oligocene sediments, Columbia River Basalt, Troutdale gravels and silts, Quaternary terrace gravels and Quaternary alluvium. The Oligocene sediments of Wilkinson and others are the oldest rocks in the area. They were assigned to the oligocene on the basis of fossil assemblages found in various parts of the St. Helens Quadrangle. Elements of the Scappoose Formation are contained within the Oligocene age sediments described by Wilkinson and others, however, and the Scappoose Formation was found by Kelty (1981) to contain cobbles of low Mgo Grande Ronde Basalt, suggesting that the oligocene sediments of Wilkinson and others may in fact be partially of Miocene age. Wilkinson and others (1946) described the lithology of the oligocene age sediments as '...mostly massive, medium- to fine-grained tuffaceous sandstone 
with some gritty and conglomeratic components. They are commonly gray in color weathering to buff or yellowish brown...' (Wilkinson and others, 1946). Abundant woody fragments were found in the 'Oligocene sediments' and caused Wilkinson and others to suggest that the sediments might be of non-marine origin. Wilkinson and others found it difficult to obtain reliable bedding orientations in the sediments, but indicated that sediments are generally shallowly dipping and appear to be gently folded. They attributed steeper dips found at some localities to possible faulting in the area, but were unable to present a rigorous structural interpretation of the area.

Wilkinson and others mapped large thicknesses of CRB on top of the Oligocene sediments. They were unable, however, to differentiate the groups of flows. The CRB is given a total thickness in the Chapman Quadrangle of about 200 meters. Limonite deposits are associated with the CRB Group flows at various locations in the Chapman Quadrangle. These deposits range up to about $50 \%$ iron and were thought by previous workers to represent 'bog iron' deposits formed during a period of quiescence during the outpouring of the basalt (Miller, 1938, Wilkinson and others, 1946). These 'bog iron' deposits, together with sand, gravel and quarried Columbia River 
Basalt, represent the only materials mined for economic gain in this area. 


\section{CHAPTER II}

\section{FIELD MAPPING}

\section{INTRODUCTION}

The bedrock and soils of the study area were mapped during the summers of 1981 and 1982, and are presented as Figure 4 and Figure 5 respectively. The bedrock units of this area had been mapped previously by Wilkinson and others (1946) and Hook (1976). This area was chosen for mapping because of the presence of ferruginous bauxite developed from CRB. The relationship between bedrock units and ferruginous bauxite was examined to determine the extent of bedrock control on ferruginous bauxite development.

\section{STRATIGRAPHY OF BEDROCK UNITS}

The stratigraphy of bedrock units found in the study area is presented diagrammatically as Figure 6 . The oldest unit is a cobble paraconglomerate with interbedded sands found cropping out along the axis of an anticline near Boozer Road (Sections 9 and 10 T4N R2W). This unit was mapped by Wilkinson and others as a portion of their 'Oligocene sediments', but was separated out because of its unique petrologic nature and stratigraphic position and mapped as pre-CRB conglomeratic sediments in this study. Both aphyric basalt and dioritic cobbles 


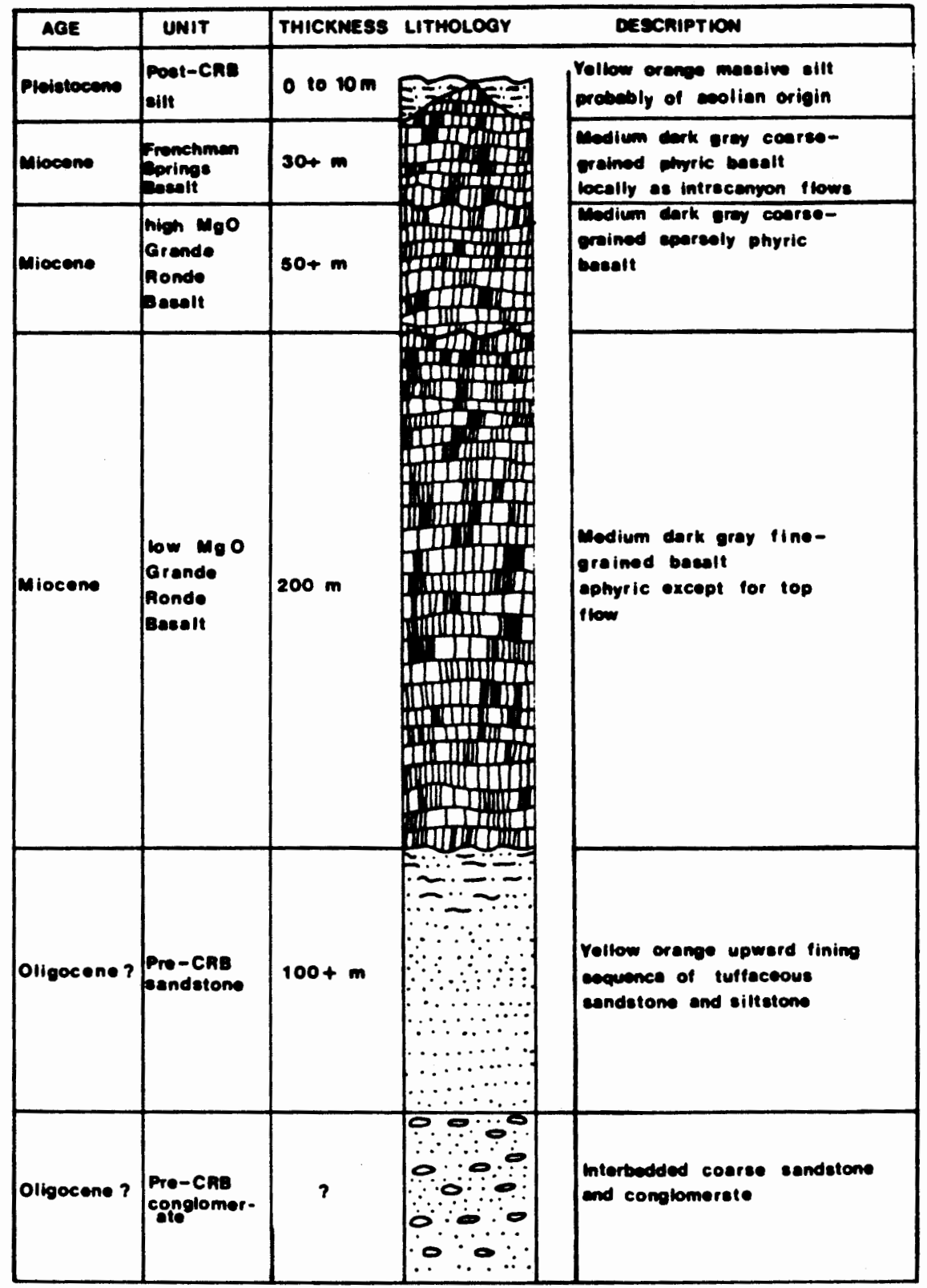

Figure 6. Stratigraphic column showing bedrock units present in the study area. 
are found in the conglomerate. Trace element chemistry of two cobbles from the conglomerate shows the basalt cobbles to be lower in Sc, Th and total $\mathrm{Fe}$ as $\mathrm{Fe}_{2} \mathrm{O}_{3}$ $\left(\mathrm{Fe}_{2} \mathrm{O}_{3 t}\right)$ than CRB Group samples analyzed. Low Sc concentrations typify the older basalts found in the coast Range of oregon (M.H. Beeson, personal communication, 1982), and this suggests that the cobbles may have been derived from pre-CRB basalts; perhaps the Goble volcanics which occur as outcrops near the study area. The preCRB conglomerate is overlain conformably by $100+$ meters of upward-fining tuffaceous mica-bearing sands and silts mapped as pre-CRB sandstone and siltstone. Handsample examination of numerous samples in the field and laboratory and petrographic examination of six thin sections prepared from sediments showed abundant feldspar, lithic fragments and muscovite in these sediments.

The sedimentary units are unconformably overlain by up to 300 meters of CRB which was divided into three mappable units on the basis of field appearance and chemistry. The oldest unit found in the study area is the informal low Mgo Grande Ronde Basalt. These flows are overlain successively by flow(s) of the informal high Mgo Grande Ronde Basalt and of the Frenchman Springs Member of the Wanapum Basalt. Low Mgo Grande Ronde Basalt of the study area grades from coarse- 
grained flow centers to fine-grained flow tops and bottoms, and is generally finer-grained than the other basalt units of the study area. The top flow of low Mgo Grande Ronde Basalt, the Winter Water flow, contains abundant blocky phenocrysts of plagioclase up to $1 \mathrm{~cm}$ on a side and may be confused with the overlying high Mgo Grande Ronde Basalt; all other low Mgo Grande Ronde flows are aphyric. High Mgo Grande Ronde Basalt is sparsely phyric and somewhat coarser-grained than the other basalts found in the area and contains plagioclase phenocrysts up to $3 \mathrm{~cm}$ on a side.

The basalt units can be differentiated chemically on the basis of $\mathrm{Cr}, \mathrm{Th}, \mathrm{Fe}_{2} \mathrm{O}_{3 \mathrm{t}}$ and other elements (Figure 7). Low MgO Grande Ronde Basalt samples have low concentrations of $\mathrm{Cr}$ (below $25 \mathrm{ppm}$ ), low values for $\mathrm{Fe}_{2} \mathrm{O}_{3 t}$ (well below 148) and high concentrations of Th (above $4 \mathrm{ppm}$ ); high MgO Grande Ronde Basalt samples collected from the study area have $\operatorname{Cr}$ concentrations above $30 \mathrm{ppm}, \mathrm{Fe}_{2} \mathrm{O}_{3 t}$ values below 148 and $\mathrm{Th}$ values below 4 ppm; Frenchman Springs Basalt samples collected from the study area have high $\mathrm{Cr}$ (44 ppm), high $\mathrm{Fe}_{2} \mathrm{O}_{3 t}$ (15.38) and Th above $4 \mathrm{ppm}$. The average concentrations of elements detected in basalt samples from the study area are listed in Table I. 

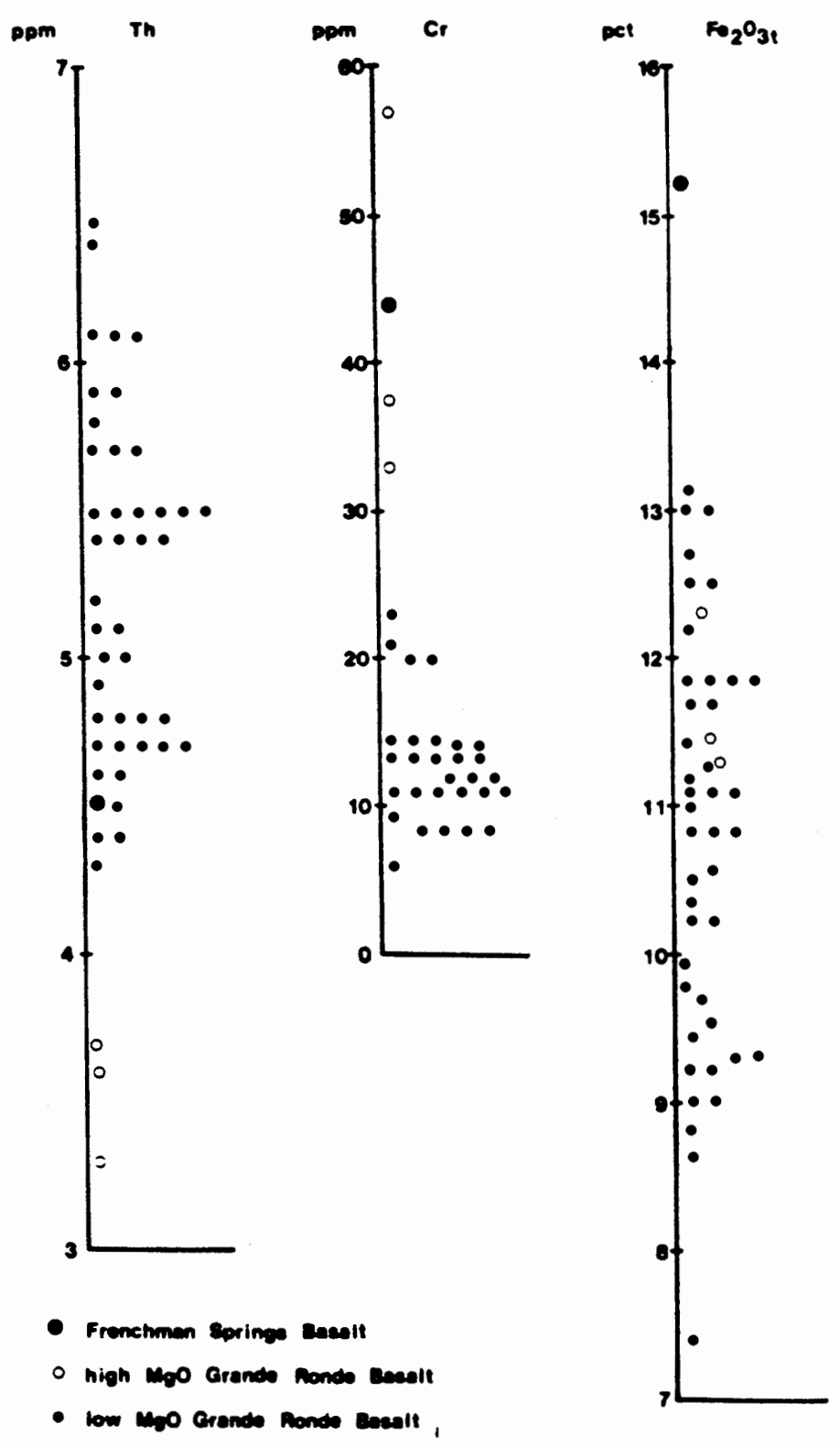

Figure 7. Concentrations of selected elements detected in basalt samples from the study area. 


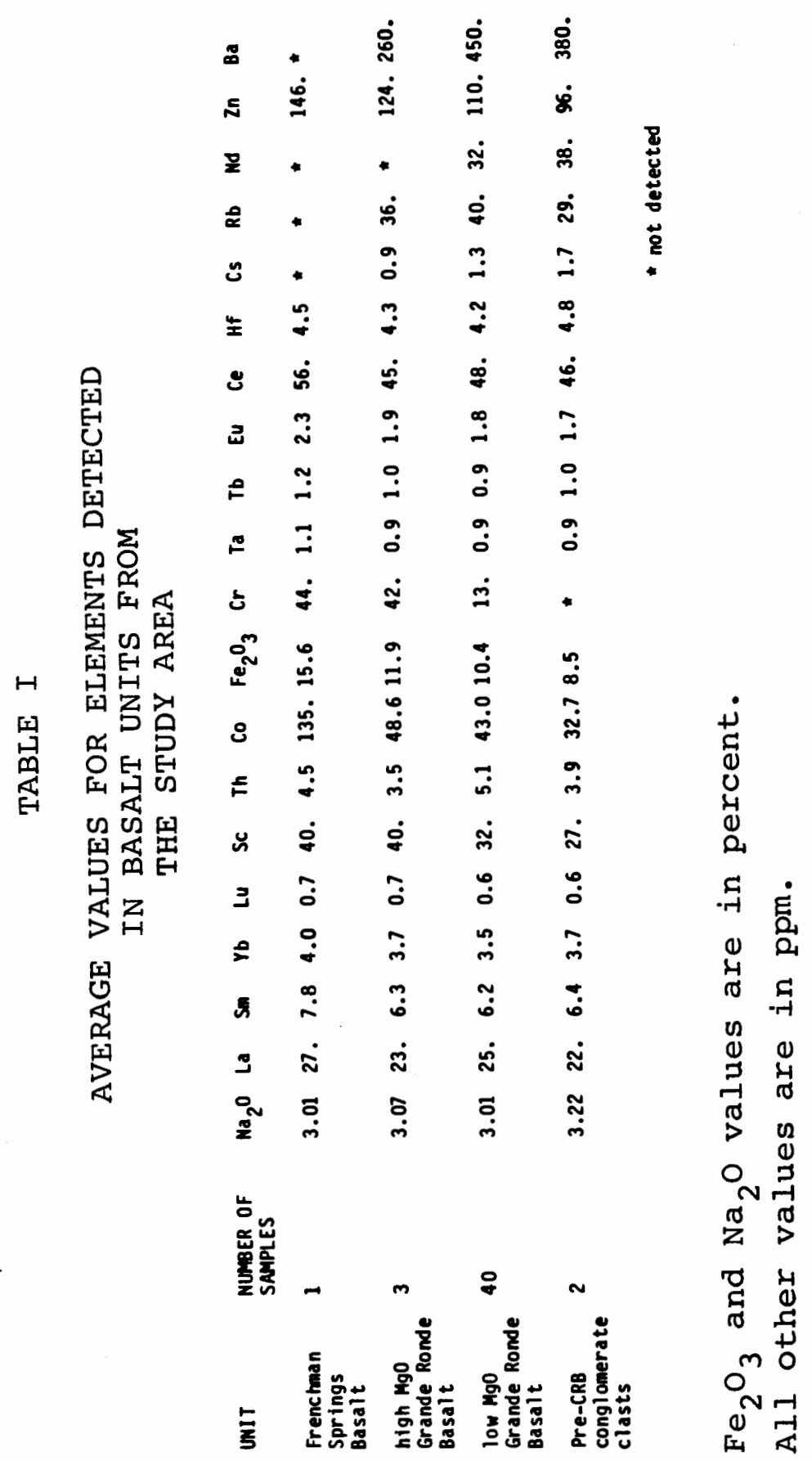


Approximately 100 meters of Frenchman Springs Basalt directly overlie low MgO Grande Ronde Basalt in the center of the study area (section 15, 16, 21 and $22 \mathrm{~T} 4 \mathrm{~N}$ R2W) . This basalt probably came into this area as an intracanyon flow as evidenced by the thickness of the flow which greatly exceeds the maximum flow thickness seen in other portions of the study area and by the lack of high Mgo Grande Ronde Basalt in this area. In other parts of the study area the low Mgo Grande Ronde, high MgO Grande Ronde and Frenchman Springs Basalts lie in a normal stratigraphic succession with disconformities between the units. The average thickness of low Mgo Grande Ronde, high Mgo Grande Ronde and Frenchman Springs Basalts in the study area are 200 meters, 50 meters and 30 meters respectively.

The stratigraphically highest units mapped on the bedrock geology map are: a layer of post-CRB silt which overlies the older rocks found in the study area at elevations up to 400 meters; and Quaternary alluvium and terrace gravels which cover much of the study area and were mapped together as Qal. The post-CRB silt was only mapped in those areas where it totally obscured the underlying older units. Several silt units occur in the Willamette Valley and surrounding environs. The most widespread are the Portland Hills silt which is 
a thick unit of loess which commonly overlies CRB Group flows and quartzite pebble-bearing conglomerates and vitric sandstones of the Troutdale Formation (Lentz, 1981), and the stratigraphically higher willamette silt which formed in the region as slack water deposits following the spokane floods (Bretz and others, 1956, Glenn, 1965). The silt of the study area occurs and was probably deposited at elevations up to 400 meters. The widespread distribution, elevation of deposition and massive nature of the silt found in the study area suggest that the silt is predominantly of aeolian origin and probably correlative to the Portland Hills silt.

\section{SOIL UNITS}

Figure 5 maps the distribution of soil units found in the study area. The soils of the study area were mapped on the basis of color, parent material and degree of development. Pre-CRB sandstone and conglomerate weather to produce a yellow-orange soil containing inclusions of unweathered sediments. This soil is colored red in places by local iron contamination in areas where CRB is inferred to have been present in the past. The post-CRB silt produces a yellow-orange soil which closely resembles the soil produced by the preCRB sediments. This ubiquitous material drapes over other units and was mapped only where it reached 
sufficient thickness to totally obscure underlying units. Recent river deposits from Scappoose Creek and the Willamette River together with Pleistocene terrace gravels were mapped as Qal. These deposits cover much of the study area at elevations up to 100 meters, covering whatever may be underneath. The distribution of light colored soils derived from pre-CRB sandstone and siltstone, post-CRB silt and Quaternary alluvium parallel the distribution of the parent materials on the bedrock geology map.

The basalt found in the study area shows a remarkable degree of variability in the amount of weathering and gives rise to quite variable thicknesses of soil. Fresh basalt without any weathering mantle crops out along Scappoose Creek. Areas of weathered basalt which partially preserve the original basalt structure and texture (saprolite) occur throughout the study area, and are interspersed with areas of more highly weathered basalt which form red soils identified in the field as ferruginous bauxite on the basis of similarity to materials analyzed by Libbey and others (1945). Basaltderived soil units were mapped separately on the soils map. Contacts between the units are, however, approximate and gradational in all cases. 
STRUCTURE

Strikes and dips are easily obtained from the sedimentary units of the study area, and are generally fairly shallow. The only clearly definable fold found in the study area is a doubly plunging anticline which occurs near Boozer Road exposing older conglomeratic sediments along its axis. Strikes and dips were not obtained directly from the basalt and weathered basalt found in the study area. Contacts between basalt flows tend to follow contour lines, and generally behave as if the units are flat lying.

Faults are very common in the study area, appearing as lineations on SLAR, Landsat and aerial photographs and as offset beds, springs and zones of 'bog iron' and breccia. N 20 to $35^{\circ} \mathrm{W}$ trending faults such as those which run down the Scappoose Creek-Alder Creek and Cedar Creek drainages are the best developed and clearest faults in the area. These faults parallel the trend of the Portland Hills Fault as seen on SLAR and Landsat photographs and are surrounded by fairly large shear zones (Haas, 1983). Vertical separation on the Scappoose Creek-Alder Creek fault is approximately 100 meters; vertical separation on the Cedar Creek fault is also approximately 100 meters. Sag ponds are present along the trend of the Scappoose Creek-Alder Creek fault in 
section 36 T5N R3W suggesting that the fault may have experienced movement during the Quaternary.

$\mathrm{N}$ and $\mathrm{NE}$ trending faults were also mapped in the study area, and have vertical separations up to 100 meters. These faults do not, however, produce lineations as strong as those produced by the NW trending faults. $\mathrm{N}$ and $\mathrm{NE}$ trending faults also apparently lack the well developed shear zones seen along the NW trending faults.

\section{FERRUGINOUS BAUXITE DEVELOPMENT}

Basalt found in the study area has been pervasively weathered to saprolite and ferruginous bauxite except along Scappoose Creek where fresh basalt has been exposed by the creek. Basalt which has been weathered to saprolite is found intimately associated with basalt which has weathered to ferruginous bauxite throughout the study area in a manner which is not adequately explained by previous theories about the factors controlling ferruginous bauxite development. The blanket theory of ferruginous bauxite development proposed by Libbey and others (1945) and Corcoran and Libbey (1956) suggested that ferruginous bauxite developed over all exposed CRB and was preserved at favorable locations, such as hill tops, where the ferruginous bauxite was not removed by erosion. There are many hill tops underlain by basalt in the study area. Some are covered with 
ferruginous bauxite such as those in section $22 \mathrm{~T} 4 \mathrm{~N}$ R2W while others, apparently equally well protected from erosion, such as those in section $32 \mathrm{~T} 4 \mathrm{~N}$ R2W are bare saprolite with no evidence that ferruginous bauxite was ever present. The blanket theory cannot, therefore, explain the distribution of ferruginous bauxite seen in the study area.

Hook (1976) suggested that bauxite developed in response to the development of 'youthful topography'. The steepest topography in the study area is that associated with the Scappoose Creek Valley. Slopes in this area contain almost no ferruginous bauxite, suggesting that steep and presumably well drained topography is not enough for ferruginous bauxite development. The slopes on the hills in section 22 and section $32 \mathrm{~T} 4 \mathrm{~N}$ R2W which bear and lack ferruginous bauxite respectively are approximately the same, suggesting that ferruginous bauxite development can both occur and fail to occur under the same topographic conditions. Hook's theory does not seem adequate to explain the distribution of ferruginous bauxite in the study area.

C.W. Hoffman (1981) showed a correlation between the distribution of ferruginous bauxite deposits and the distribution of what was believed to be the Kelley Hollow flow of the Frenchman Springs Basalt in the Salem Hills of Marion County, Oregon. Examination of Figure 4 and 
Figure 5 shows that a correlation does not exist between any specific basalt flow and the ferruginous bauxite found in the study area. Ferruginous bauxite has developed from low Mgo Grande Ronde Basalt, high Mgo Grande Ronde Basalt and Frenchman Springs Basalt.

Investigation of the geology of the study area did, however, turn up a possible correlation between the structure of the area and ferruginous bauxite development. The best developed ferruginous bauxite deposits are associated with shear zones and faults. The thickest zones of ferruginous bauxite occur in the center and in the north of the study area where basalt bedrock is cut by the Scappoose Creek-Alder Creek fault zone, and the relationship between faulting and ferruginous bauxite development can be clearly seen in miniature in section 3 T4N R2W where a small NE trending normal (?) fault separating high MgO Grande Ronde Basalt and low Mgo Grande Ronde Basalt saprolite has produced a 30 meter wide zone of fault gouge. The fault gouge is overlain by approximately 5 meters of ferruginous bauxite; the only ferruginous bauxite found in the immediate area (Figure 8).

It is possible that faulting has influenced the rate of basalt weathering by either increasing the particle surface area in contact with groundwater or by 


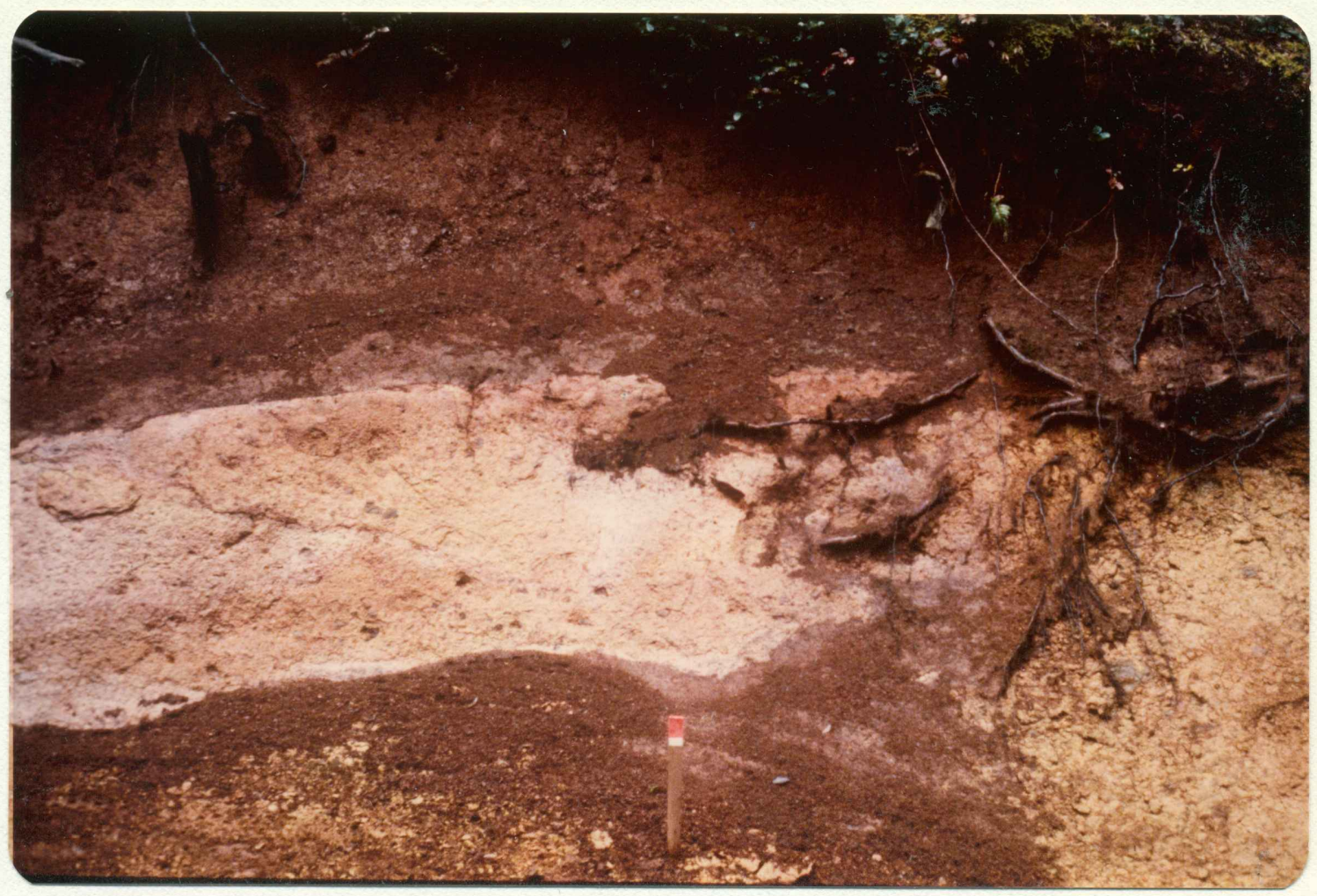

Figure 8. Photograph of a fault and overlying ferruginous bauxite. 
producing pathways for the movement of groundwater by increasing the permeability of the basalt flows. An increase in particle surface area would result from the formation of fault gouge and mylonite during faulting. The greater surface area of these particles as compared to the original basalt would then influence the kinetics of the weathering reactions and allow them to proceed with greater speed and, therefore, to a greater degree in a given length of time.

The formation of gouge zones should increase the permeability to water of the basalt, permitting the faults to act as routes for the removal from the system of solutions carrying weathering products. Iron-rich solutions such as those presumed to be responsible for ferruginous bauxite formation should deposit iron locally in the fault zone as they move downward through the zone (M.H. Beeson, personal communication, 1983), and the movement of these iron-rich solutions should impart a red or an orange color to the materials through which the solutions pass. The lack of a red or orange color indicative of iron concentration in Figure 8 is probably caused by conditions being unfavorable for iron deposition at this location. This hypothesis is favored because of a very strong correlation in the study area between 'bog iron' deposits and faults 
showing that iron-rich solutions have, at least in some instances, moved through faults, leaving iron behind. 


\section{CHAPTER III}

\section{PISOLITIC ZONE FERRUGINOUS BAUXITE}

\section{INTRODUCTION}

Ferruginous bauxite deposits profiles and underlying basalt are commonly divisible into a series of zones (Figure 2). From bottom to top these zones are: a fresh basalt zone, a saprolite zone, an earthy zone of ferrginous bauxite, a nodular zone of ferruginous bauxite and a pisolitic zone of ferruginous bauxite. The mechanism behind the origin of this zonal pattern has not been fully elucidated by previous workers, and one of the purposes of this work was to determine, if possible, the mechanism by which some of these zones are formed. Two main hypotheses have been proposed to account for the formation of the zones. The first hypothesis proposed by Libbey and others (1945) and supported by most subsequent workers is that the zones formed because of inhomogeneous conditions in the weathering profile. The second hypothesis proposed by Jackson (1974) is that some zones resulted from aqueous reworking of pre-existing ferruginous bauxite. Careful examination of the pisolitic zone ferruginous bauxite was undertaken to settle part of the controversy. 
The pisolitic zone of ferruginous bauxite deposits contains rounded inclusions which have been described by various authors as either pisolites or oolites. Pisolites are spherical to subspherical bodies formed in the vadose zones of soils. Oolites on the other hand are spherical to ellipsoidal bodies formed by the precipitation of material about a core in a subaqueous, high energy environment (Blatt and others, 1980). Pisolites and oolites have also been differentiated on the basis of size. The term pisolite was formerly reserved for spherical bodies greater than $2 \mathrm{~mm}$ in diameter while the term oolite referred to spherical bodies between 0.25 and $2 \mathrm{~mm}$ in diameter. For convenience, the term pisolite will be used without genetic implications for the subspherical bodies found in ferruginous bauxite deposits.

Three distinct forms of pisolites are found within the ferruginous bauxite deposits of Columbia County (Livingston, 1966, Jackson, 1974, Hook, personal communication, 1982): a clay-rich variety (Figure 9); a highiron variety composed of magnetic iron hydroxides which are opaque in thin section and commonly contain angular quartz inclusions (figure 10 and Figure 11); and a highaluminum variety rich in cliachite (amorphous aluminum oxides and hydroxides). High-aluminum pisolites were 

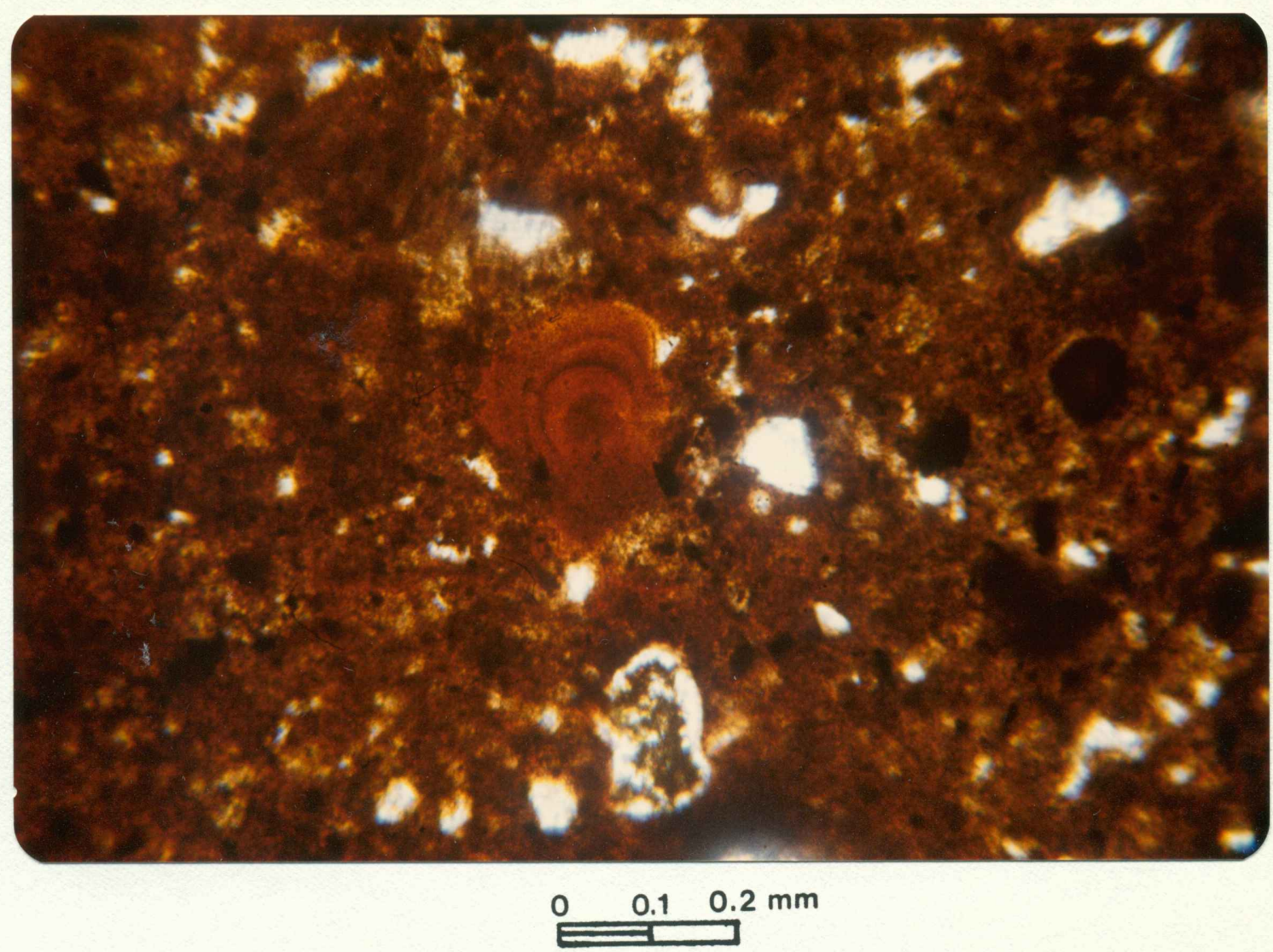

Figure 9. Photomicrograph of a clay-rich pisolite under plane polarized light. 


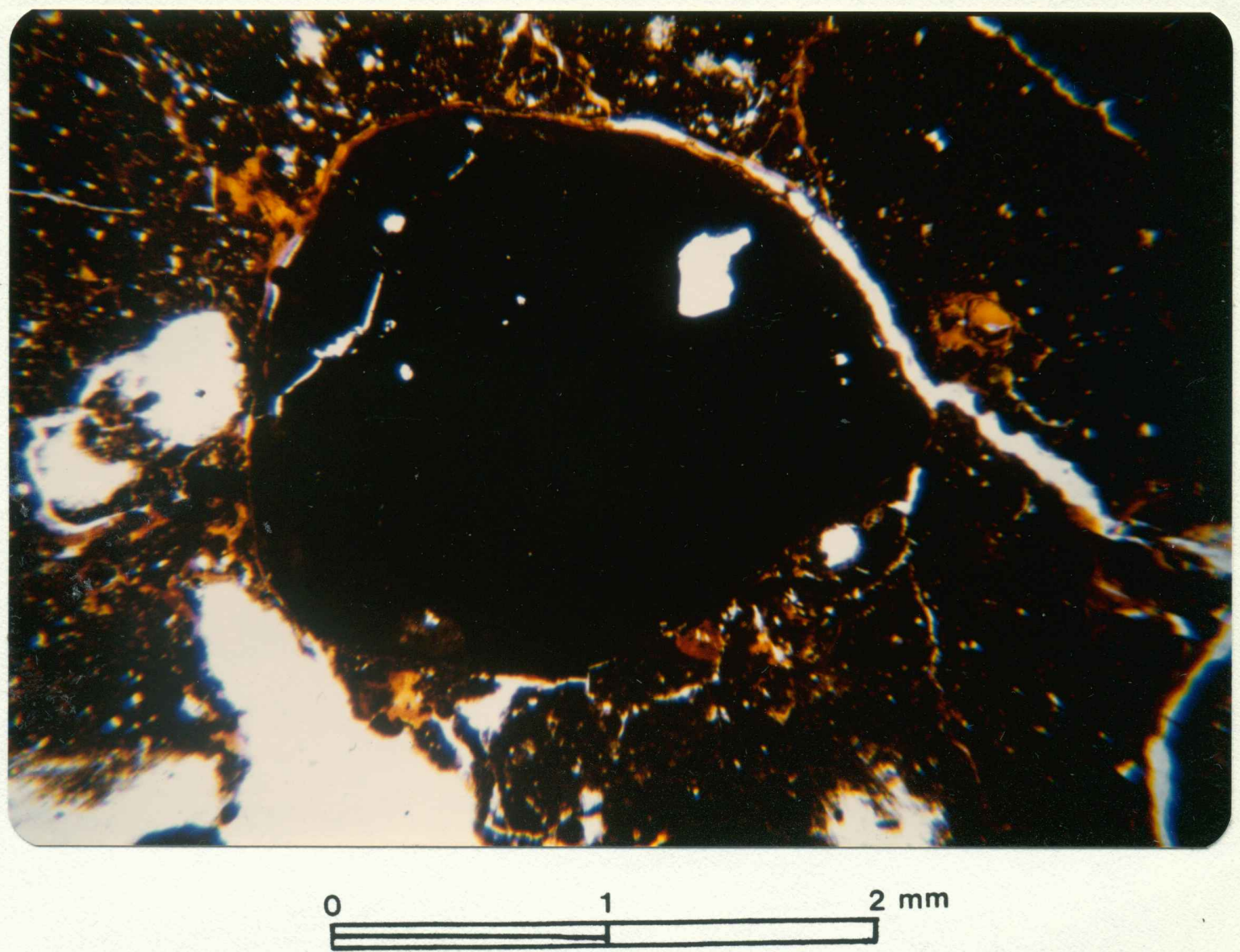

Figure 10. High iron pisolite and angular quartz inclusions shown under plane polarized light. 


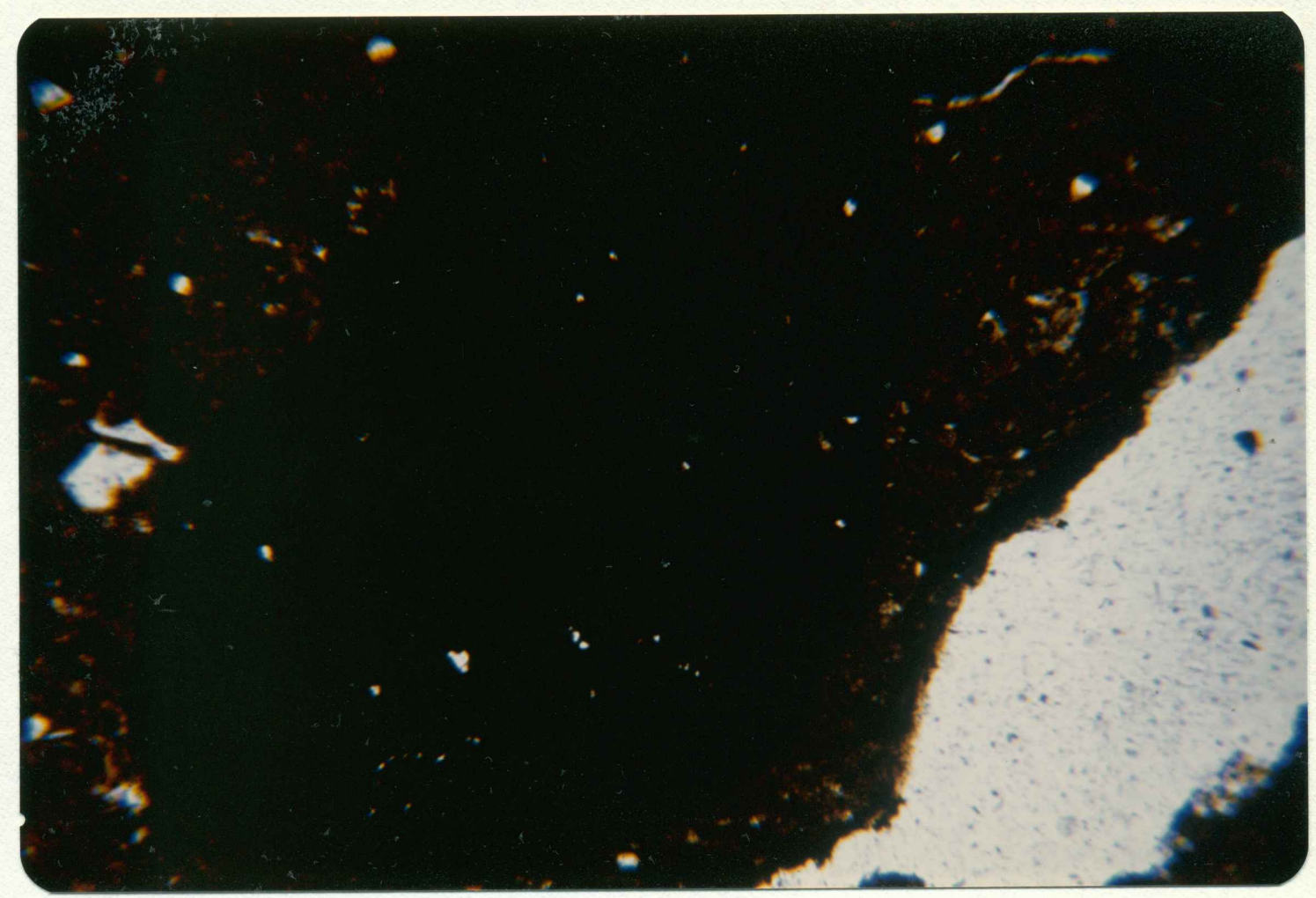

\section{$0.1 \quad 0.2 \mathrm{~mm}$}

Figure 11. High iron pisolite under plane polarized light showing clear quartz inclusions in the dark mass of the pisolite. 
not collected from surface exposures in the Chapman Quadrangle. The focus of this study will, therefore, be on the high-iron variety of pisolite.

\section{DATA AND DISCUSSION}

Both sedimentary and weathering processes have been invoked to explain the presence of pisolites in the ferruginous bauxite deposits of oregon and Washington. Jackson (1974), working with a zone containing high-iron pisolites similar to those shown in Figure 10 and Figure 11 suggested that the zone of pisolitic ferruginous bauxite present in the deposits of Columbia County, oregon and Wahkiakum County, Washington formed where weathered basalt was reworked by fluvial processes. Jackson's theory suggests that the pisolites were formed by accretion during fluvial transport. Jackson suggested that the silica contained within the pisolites as quartz inclusions represented detrital material incorporated into the pisolites during formation (Jackson, 1974). Libbey and others (1945), during their examination of the pisolites from ferruginous bauxite profiles, noted the presence of small, high-iron pisolites within larger, high-iron pisolites. As part of the present study, pisolites were mechanically separated from their ferruginous bauxite matrix, and it was noted that some of the pisolites showed overgrowths of dark, apparently 
authigenic material which bound the smaller pisolites together into larger structures. These dark, apparently iron-rich overgrowths suggest that iron oxides may be deposited from solution within ferruginous bauxite deposits. The joined pisolite structure was much too fragile to withstand transportation. Unfortunately it is very uncommon for pisolites to actually touch, and the uniform pisolite distribution made it difficult to find more than a few examples of authigenic overgrowths on pisolites.

Pisolitic ferruginous bauxite outcrops examined in the field were devoid of any trace of size sorting. Pisolites ranging in diameter from less than $2 \mathrm{~mm}$ up to $15 \mathrm{~mm}$ were randomly distributed throughout the ferruginous bauxite matrix. Fluvial movement of the pisolitic zone ferruginous bauxite as postulated by Jackson (1974) should probably have resulted in size sorting within the zone similar to the sorting seen in fluvially reworked pisolitic bauxite from the Arkansas bauxite region (Gordon and others, 1958). Post-depositional mass movement of the ferruginous bauxite might partially obscure size sorting in some areas, but Libbey and others (1945), Livingston (1966), Jackson (1974) and Hook (1976) all failed to find any evidence of size sorting in pisolitic ferruginous bauxite. 
Jackson's chief argument supporting a fluvial origin for the pisolites of the pisolitic zone was that the abundant angular quartz inclusions found in highiron pisolites from Wahkiakum County were detrital quartz picked up and included in pisolites as the pisolites formed in a fluvial environment. Similar pieces of angular monocrystalline quartz are present in the pisolites of the Chapman Quardrangle (Figure 10 and Figure 11). Pisolites formed by fluvial action should have picked up a representative cross-section of the particles present in the stream. All of the sandstone and siltstone found within the study area contain abundant feldspar, mica and rock fragments which should have been picked up along with the quartz which was present if Jackson's mechanism for formation is correct. The absence of these materials from the pisolites suggests that the quartz grains do not represent sediment included in the pisolites during subaqueous formation.

\section{CONCLUSIONS}

Jackson's chief argument in favor of a fluvial origin for the pisolites of the pisolitic zone centered on the inclusions of 'detrital' grains of quartz found contained in pisolites. These quartz inclusions do not appear to represent detrital quartz, therefore, the chief argument in favor of a detrital origin for the pisolites 
does not stand up to careful scrutiny. In addition, the pisolitic zone of ferruginous bauxite does not exhibit size sorting as would be expected if the zone had been reworked by fluvial action, and there are what appear to be authigenic overgrowths associated with some pisolites and groups of pisolites. The exact mechanism of formation of pisolites is unclear (Keller, 1979), but the location of high-iron pisolites in the upper, probably more oxygenated, zone of ferruginous bauxite deposits suggest an Eh controlled mechanism of formation. Iron could be leached from lower zones of the deposit and carried upward by capillary action as proposed by Corcoran and Libbey (1956) for deposits of the Salem Hills area. A limited number of nucleii, formed in the pisolitic zone, could then act as loci for iron precipitation when conditions in the pisolitic zone were oxidizing. Quartz was probably preciptiated either at the same time as iron deposition or during alternating periods of iron and quartz deposition. 
CHAPTER IV

SOIL MINERALOGY

\section{INTRODUCTION}

The set of minerals which form from a given bulk composition during weathering depends on the physical conditions during mineral formation as well as on the initial bulk composition. $\mathrm{Eh}, \mathrm{pH}$ and other conditions influence the minerals which form. It is possible to deduce the mineral assemblage which will form from an initial bulk composition if the physical conditions during mineral formation are well enough known, and it is possible to look at the mineral assemblage representing an initial bulk composition and deduce within limits the physical conditions under which the minerals formed. The mineral content of soil and saprolite samples from the study area was studied using $\mathrm{x}$-ray diffraction techniques (Brown, 1961, Carroll, 1970a, Gabor, 1981) to try to determine something about the conditions of $\mathrm{pH}$, Eh and leaching under which ferruginous bauxite deposits formed.

\section{EXPERIMENTAL METHOD}

X-ray diffraction techniques can be used to identify clays and other minerals present as greater than about 
108 of the analyzed sample. The x-ray diffraction portion of this study concentrated on identification of clay minerals because of their usefulness as environmental indicators (Degens, 1965). There are five major groups of clay minerals: the kandite group; the mica group; the montmorillonite (or smectite) group; the vermiculite group; and the chlorite group. Of these groups the kandite and smectite groups are the onlyones identified by previous workers in ferruginous bauxite deposits. Experimental methods were designed to identify the families present, and an attempt was made to differentiate between the members of the kandite and smectite families. Table II provides the $\mathrm{d}_{001}, \mathrm{~d}_{002}$ and $\mathrm{d}_{003}$ spacings used to identify the minerals present in soil and saprolite samples. A detailed explanation of the sample preparation procedures is presented in Appendix I.

The mineralogical study was limited to determination of the presence or absence of a given mineral in a sample. Quantitative clay mineralogy has been attempted by various workers, but the results are generally unsatisfactory (Carroll, 1970a). Different groups of clay minerals are often concentrated in different size fractions; smectite, for example, tends to be relatively more concentrated in the -0.2 micron size class. To obtain the best $x-r a y$ diffraction results samples for this 
TABLE II

\section{$X$-RAY PEAKS USED TO IDENTIFY \\ CLAY MINERALS}

MINERAL

TREATMENT

$a_{001}(A) \quad d_{002}(A) \quad d_{003}$

(A)

Kaolinite

$\mathrm{Na}$ saturated 7.2

DMSO 7.2

3.6

a

Heated to $550^{\circ}$

3.6

‡

Smectite

$\mathrm{Na}^{+}$saturated 12-15

DMSO 17

Heated to $550^{\circ} 10$

a

a

5

Metahalloysite

$\mathrm{Na}$ saturated 7.2

DMso Heated to $550^{\circ}$ * 11.3 *

$\begin{array}{ll}3.2 & \varrho \\ \star & \vdots\end{array}$

Illite

$\begin{array}{llll}\mathrm{Na}^{+} \text {saturated } & 10 & \star & 3.35 \\ \text { DMSO } & 10 & \star & 3.35 \\ \text { Heated to } 550^{\circ} & 10 & \star & 3.35\end{array}$

Chlorite
$\mathrm{Na}^{+}$saturated 14
DMSO
14
Heated to $550^{\circ} 14$
$\begin{array}{ll}7 & \text { @ } \\ 7 & \varrho \\ 7 & \text { อ }\end{array}$
a not used for identification
* not present 
study were sized before mounting, and mounts, therefore, did not necessarily contain proportions of minerals representative of the original sample. Additional problems result from the differing orientation abilities of the different clays. Smectite, for example, is much harder to orient than the other clay minerals because of of its tendency to flocculate; the proportion of the clay which becomes oriented and contributes to the diffraction peaks is variable from one clay group to another (Carroll, 1970a).

Figure 12 is a composite $x$-ray diffractogram showing the positions and appearances of well developed peaks indicating the presence of kaolinite, smectite and metahalloysite. A Na-saturated sample, a sample treated with DMSO and a sample baked at $550^{\circ} \mathrm{C}$ are shown. Interferences due to the clay tiles on which some samples were mounted are not shown. The smectite group minerals often give better peaks when they are saturated with $\mathrm{Ca}^{+2}$ before they are $\mathrm{x}$-rayed (Carroll, 1970a); Ca saturation did not noticably improve the results and was, therefore, not used in this study.

Smectite in samples from the study area disappeared on heating to $550^{\circ} \mathrm{C}$ for two hours. Usually smectite collapses to form a peak at $10 \AA$ under such treatment. The reason for this anomalous behavior is unclear, but 


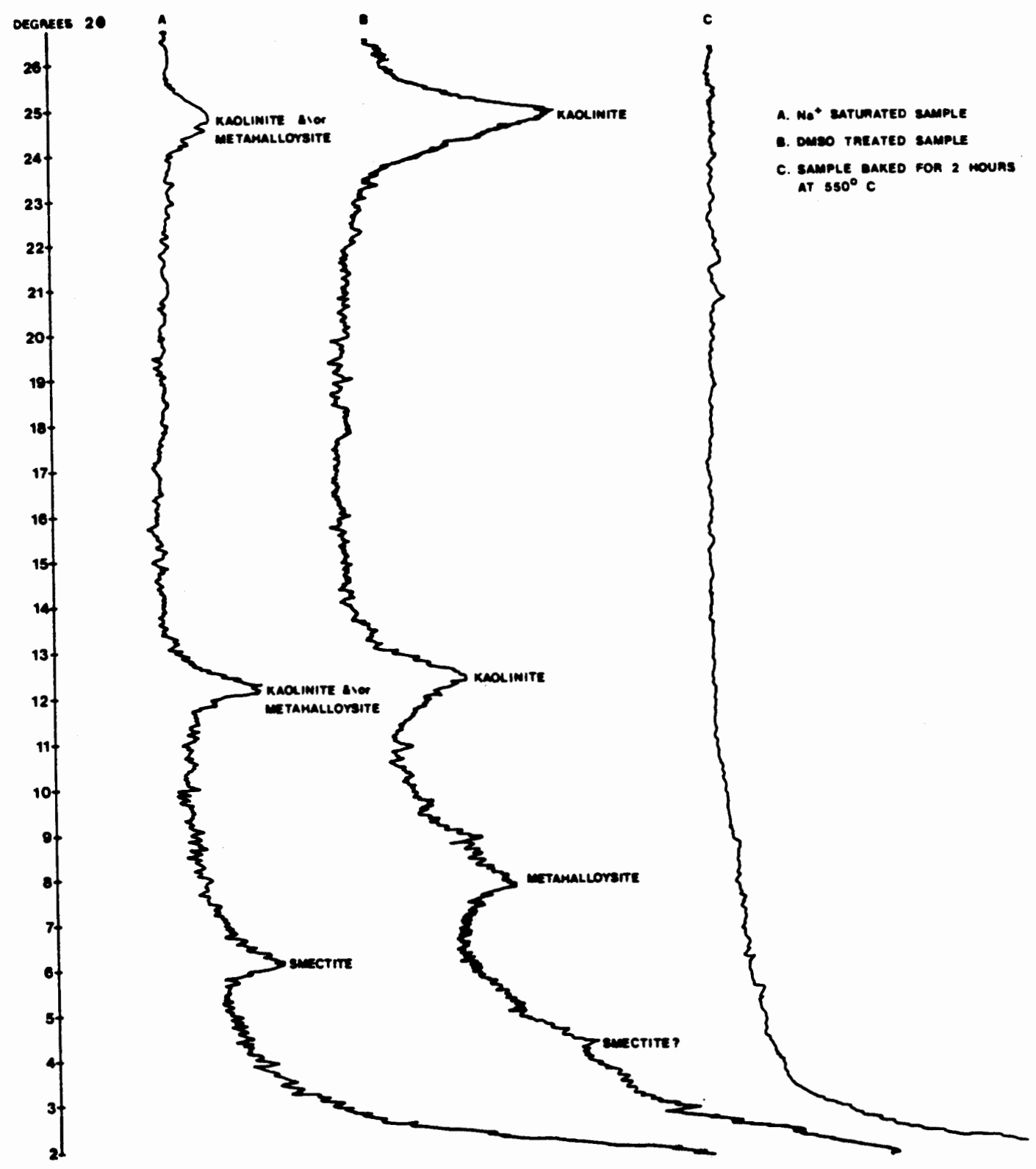

Figure 12. Composite x-ray diffractograms for a typical sample. 
may be due to the presence of smectite in interlayered structure with kaolinite, matehalloysite and/or halloysite. The disruption of the interlayered complexes caused by the destruction of kaolinite, metahalloysite and halloysite on heating may have caused the observed loss of coherent smectite.

\section{RESULTS}

Table III presents the results of the x-ray diffraction study in tabular form. Soil samples which were identified as ferruginous bauxite in the field $(27-4 \mathrm{~N}-1$ to $10,204-5$ to $7,8-25-8$ and $208-1$ to 20 ) contain detectable amounts of smectite and kaolinite, but lack detectable metahalloysite. Saprolite samples show various combinations of smectite, kaolinite and metahalloysite with smectite and kaolinițe being ubiquitous and metahalloysite being less common.

Gibbsite was not identified in samples from the Chapman Quadrangle. This result may be due to the experimental procedures used and not the absence of gibbsite from the soils of the study area. The identification of gibbsite was not of primary interest and some samples were treated to remove aluminum oxides and hydroxides prior to mounting. Samples of soils collected from the study area by Libbey and others (1945) contain iron and aluminum concentrations which fit the definition of 
点

on

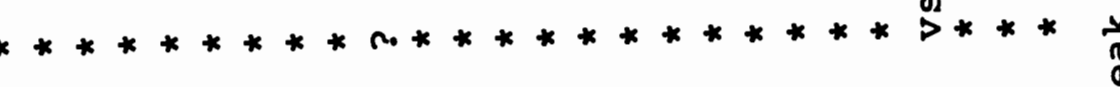

ณ

这

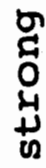

10

Ex

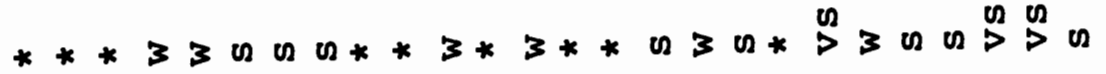

$\stackrel{4}{3}$

$\stackrel{0}{>}$

4

S

O-1

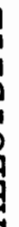

这

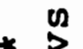

U $*$

$3 n+$

os

되니

된

少

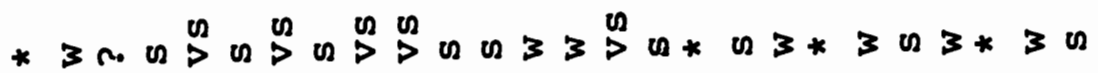

럼

A

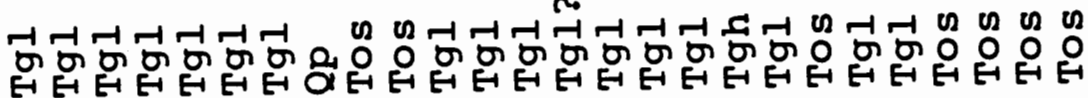

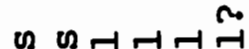

co.

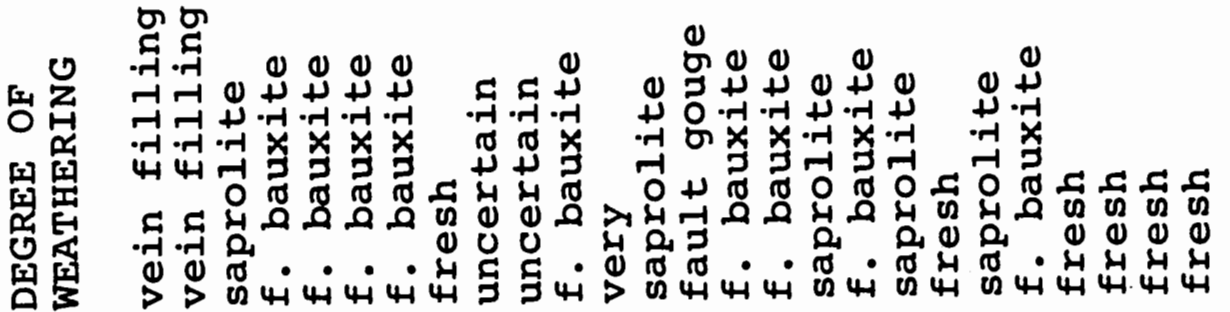

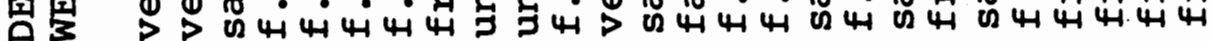

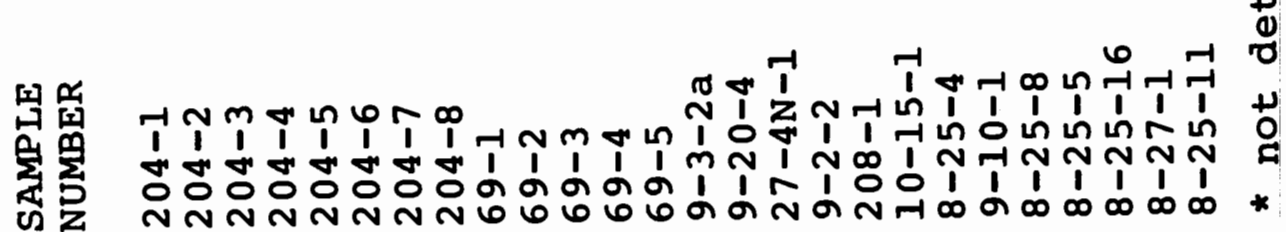


ferruginous bauxite. Previous authors (Jackson, 1971, 1974, Hook, 1976, Hoffman, 1981) have invariably found gibbsite in ferruginous bauxite from shallow as well as deep horizons.

Jackson (1974) detected quartz in samples of ferruginous bauxite from Wahkiakum County, Washington using $\mathrm{x}$-ray diffraction techniques. Quartz was not detected unequivocally by $x$-ray diffraction in samples of soil from the Chapman Quadrangle because of the presence of interfering peaks produced by the clay tiles on which many of the samples were mounted, but the presence of quartz in some samples was established by petrographic examination (Figure 10 and Figure 11).

\section{INTERPRETATION AND CONCLUSIONS}

Metahalloysite was present in many of the saprolite samples analyzed, but was lacking from the more highly weathered samples. In many weathering environments metahalloysite (or halloysite) appears during the initial phase of weathering, but subsequently decomposes to kaolinite which may or may not weather to form gibbsite (Gardner, 1970). This trend appears in the Salem Hills area (Hoffman, 1981), and the disappearance of metahalloysite from highly weathered basalt samples is confirmed here. 
In most samples kaolinite yielded broad, low peaks characteristic of poorly crystalline kaolinite, partially disordered by random layer displacements parallel to the b crystallographic axis (Carroll, 1970a). Kaolinite which has recrystallized in response to diagenetic changes becomes well ordered (Carroll, 1970a) while kaolinite formed by weathering is poorly crystalline. The presence of disordered kaolinite suggests that the kaolinite found in the study area has not recrystallized since initial formation.

Figure 13 shows the cations and conditions necessary for the formation of each clay mineral (Degens, 1965). If it is assumed that the smectite, halloysite and kaolinite found in samples from the study area formed in equilibrium with roughly the same solutions, and that these solutions are the same ones responsible for the formation of ferruginous bauxite deposits, the conditions at the time of formation of ferruginous bauxite deposits can be deduced. Smectite requires weakly acidic to weakly alkaline conditions during its formation; kaolinite forms under weakly to moderately acidic conditions; and halloysite forms under weakly acidic conditions. The presence of all three minerals in weathered samples suggests that the groundwater during formation of the ferruginous bauxite deposits was slightly acidic. 


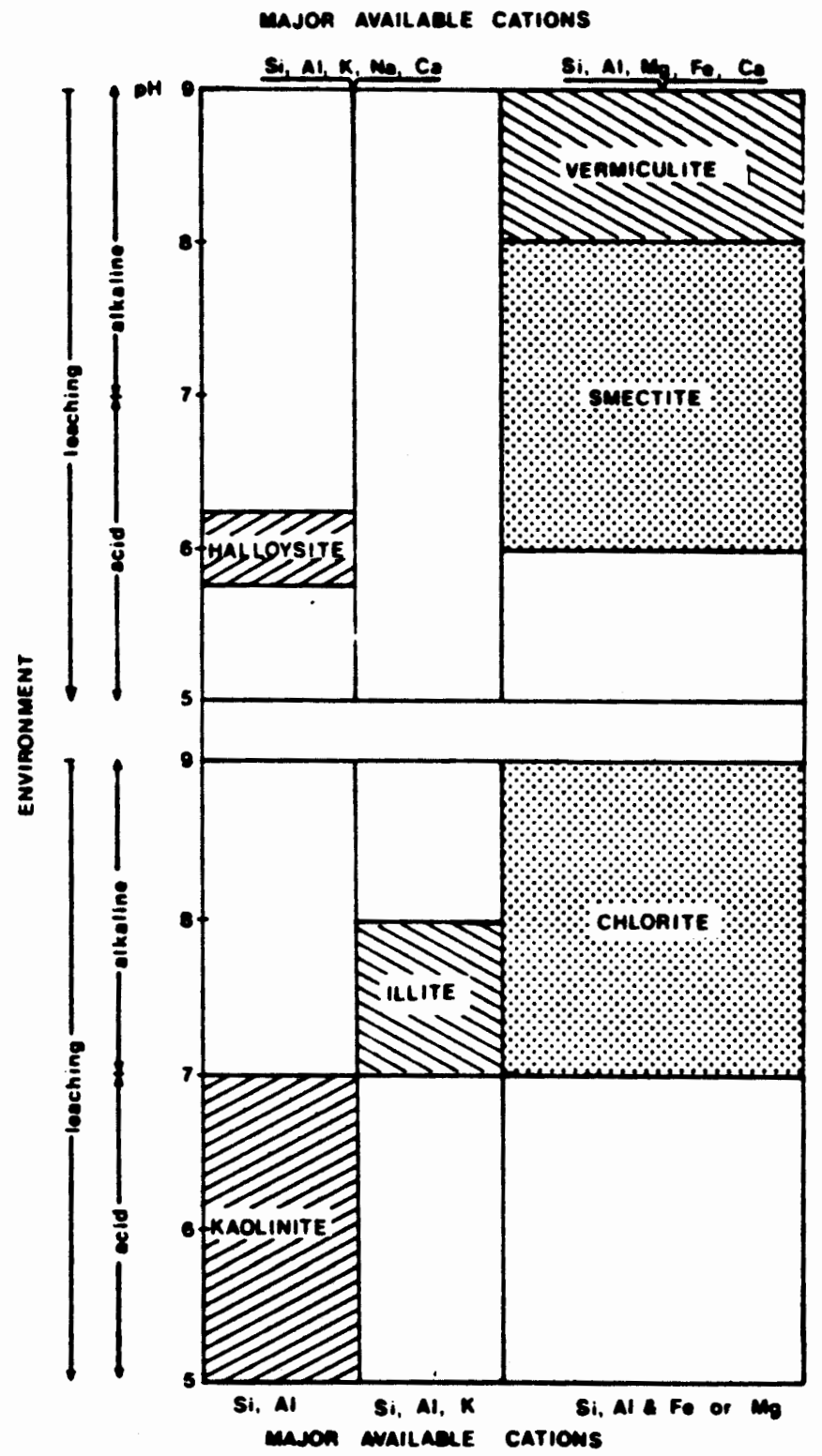

Figure 13. Conditions under which each of the major groups of clays form. From Degens (1965). 
The $\mathrm{pH}$ range between 6.0 and 6.2 is the only area where all three minerals are present and can form.

Previous authors have shown that ferruginous bauxite commonly contains the assemblage quartz, kaolinite, gibbsite. While $x$-ray diffraction data failed to show the presence of these three minerals in samples from the study area, further work will probably show that this assemblage is in fact present in many portions of the study area. Figure 14 shows the solubility lines for quartz, kaolinite and gibbsite calculated from thermodynamic data. This diagram was prepared for a $\mathrm{pH}$ of 6 and is probably representative of conditions during ferruginous bauxite formation. Interpretation of the relationships shown in Figure 14 by later authors (Gardner, 1970, Chesworth, 1975a, 1975b, Chesworth and Dejou, 1980) lead to the production of a topology for the system $\mathrm{AlOOH}, \mathrm{Fe}_{2} \mathrm{O}_{3}, \mathrm{SiO}_{2}$ (Figure 15). The tie line between goethite and kaolinite separates gibbsite stable assemblages from quartz stable assemblages.

The assemblage quartz, gibbsite is unstable. In such an assemblage gibbsite and quartz should react to form kaolinite until either quartz or gibbsite disappears from the assemblage, and while equilibrium may not be obtained in some soils Chesworth and Dejou (1980) state that equilibrium of some sort is obtained in most 


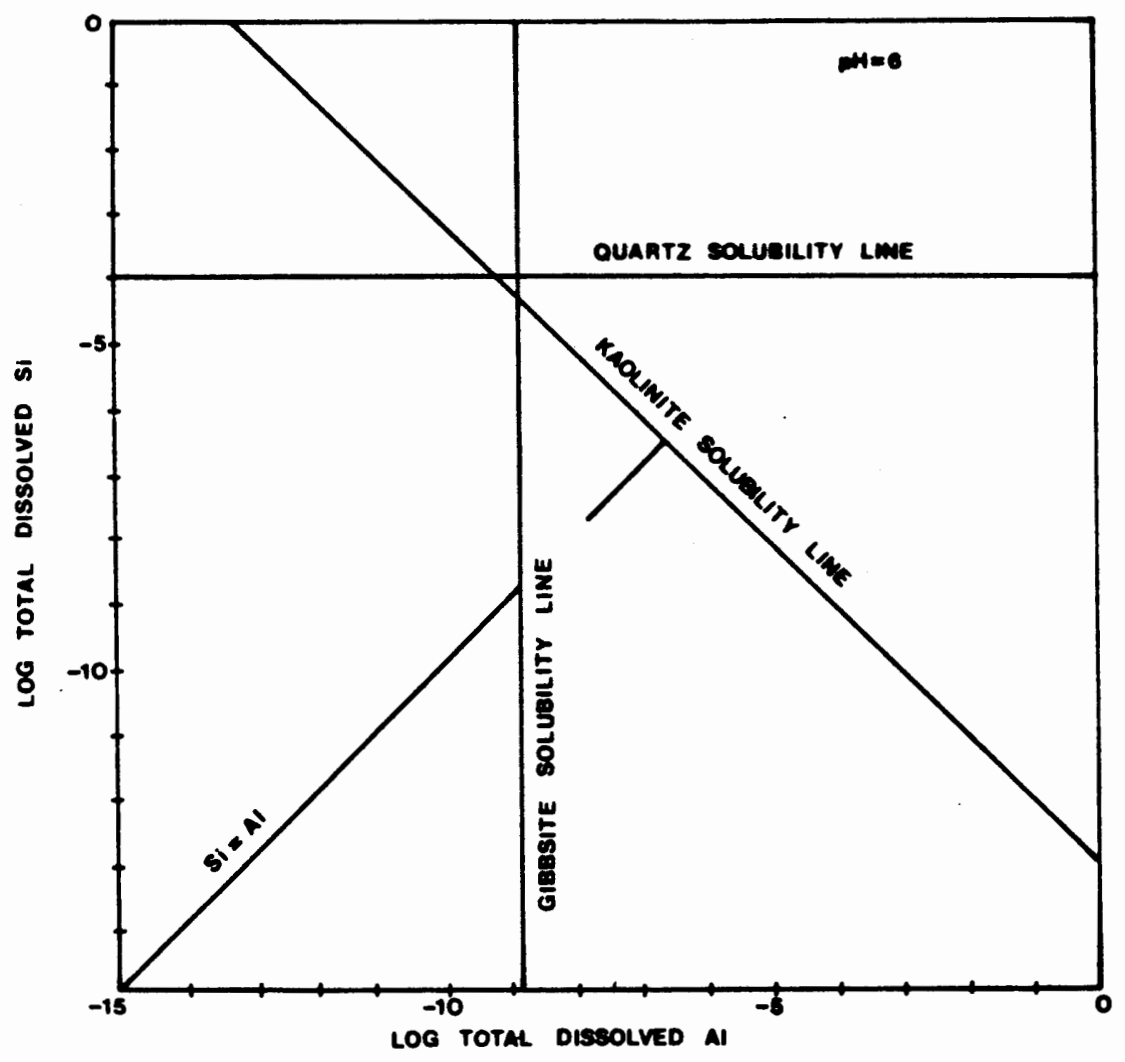

Figure 14. Solubility of aluminum and silica at a pH of 6. From Gardner (1970). 
63

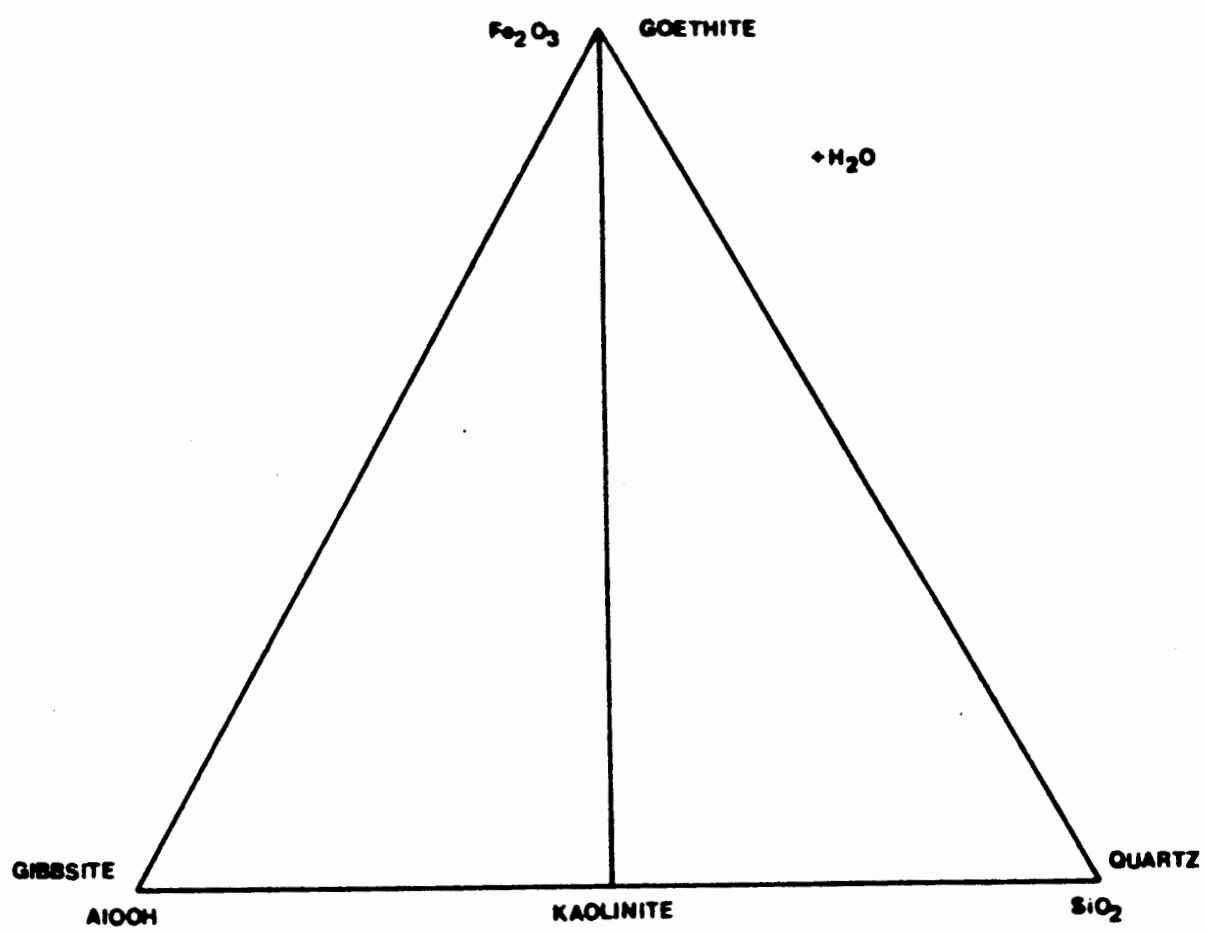

$\frac{\text { Figure } 15}{25^{0} \mathrm{C} \text { and }}$ I bar. The system $\mathrm{AlOOH}, \mathrm{Fe}_{2} \mathrm{O}_{3} \mathrm{SiO}_{2}$ at 
weathering profiles.

The photomicrographs shown in Figure 10 and Figure 11 show a mantling of detected quartz grains by iron oxides and hydroxides. The occurrence of quartz here suggests that quartz may be stable because of the mantling and may in fact be cut off for all practical purpose from equilibrium with the matrix where gibbsite exists. This in turn suggests that the formation of the pisolitic ferruginous bauxite may not have been the result of uninterrupted weathering under uniform conditions, but instead may have resulted from a series of changing conditions. Quartz and iron oxide may have been deposited under quartz stable conditions. Conditions may have changed subsequently destroying unmantled quartz and eventually depositing gibbsite. 
CHAPTER V

GEOCHEMISTRY OF WEATHERING

INTRODUCTION

Bauxitization and laterization are processes of chemical weathering produced by ground and pore waters acting on a parent material (Allen, 1948, Harder, 1949, Peterson, 1971, Zeissink, 1971). Some elements are removed by groundwater solutions moving through the parent material while other elements remain and become relatively enriched in the material left behind. Less soluble elements are concentrated by the removal of more soluble elements. No element is absolutely insoluble in water, and all elements move to some extent during laterization, but the movement of low solubility elements is often negligible.

Studies of the behavior of elements during laterite and bauxite formation are common (Corcoran and Libbey, 1956, Gordon and others, 1958, Dennen and Norton, 1977, Hoffman, 1981); the varying behavior of elements during weathering is used to ascertain the conditions under which the laterite or bauxite formed, and to predict patterns for the behavior of the elements during weathering. The lateritic materials of the Chapman 
Quadrangle were examined for their elemental abundances using instrumental neutron activation analysis (INAA). This data was used to determine the conditions during formation of the lateritic material, and to determine if the systematic behavior of elements during weathering fit any simple model.

\section{EXPERIMENTAL METHOD}

Various samples of saprolite and soils were collected from throughout the study area to supplement two series of samples of red pisolitic soil, identified in the field as ferruginous bauxite, from the NW corner of the SE $\frac{1}{4}$ of the $S E \frac{1}{4}$ of section 31 T5N R2W (samples 208-1 to 20) and from the SE corner of the NW $\frac{1}{4}$ of the NE $\frac{1}{4}$ of section $25 \mathrm{~T} 4 \mathrm{~N}$ R2W (samples $27-4 \mathrm{~N}-1$ to 10 ) which were samples along north to south trending road cuts. Ten channel samples about $10 \mathrm{~cm}$ wide, $10 \mathrm{~cm}$ deep, $20 \mathrm{~cm}$ long and spaced on $20 \mathrm{~cm}$ centers yielded about $1.5 \mathrm{~kg}$ of red soil apiece at the latter site. Twenty soil samples $10 \mathrm{~cm}$ wide, $5 \mathrm{~cm}$ deep and $40 \mathrm{~cm}$ long were taken on $60 \mathrm{~cm}$ centers from the former site. Both series of samples consisted of scattered pisolites and fragments of saprolite in matrices of red clay-rich material. Other samples from the study area were chosen to represent all stages of weathering from fresh basalt through saprolite to ferruginous bauxite. The two series of samples described 
above were numbered consecutively running from south to north along their respective road cuts. Samples were prepared and analyzed using INAA as described in Appendix A. The 27-4N samples were initially counted only once, but the results were reproduced as part of experiment $7 \mathrm{~L}$ giving two separate determinations for many of the elements present in the samples. All other samples were analyzed using two counts, and the results were not duplicated. Elemental concentrations, together with error values assigned on the basis of counting statistics are presented in Appendix B.

STATISTICAL STUDY OF ELEMENTAL BEHAVIOR DURING WEATHERING Purpose

Chemical studies of weathered materials use differences in elemental concentrations of materials in different stages of weathering to interpret conditions during weathering. Before any interpretation can be made, however, an understanding of other possible sources of chemical variation must be reached. An initial study was designed to determine the significance of differences in elemental concentrations observed in materials in different stages of weathering. A common model for laterite deposits views them as stacked horizontal layers in different stages of weathering; more weathered near the surface and less weathered at depth (Hook, 1976, 
Dennen and Norton, 1977). The initial study of weathered basalts from the study area was designed to determine the degree of chemical homogeniety in a given layer of weathered material so that interpretation of differences between different layers could be made.

Discussion

Samples $27-4 \mathrm{~N}-1$ to 10 and $208-1$ to 20 were specifically collected for this study and consist of groups of samples from two outcrops of pisolitic ferruginous bauxite. Examination of the initial determination of elemental concentrations in the $27-4 \mathrm{~N}$ samples suggests that there is significant variation in elemental concentrations between samples. If it is assumed that the actual error in determining concentrations is equal to the statistical counting error, a one-tailed statistical test will reject the hypothesis that the lowest $\mathrm{Fe}_{2} \mathrm{O}_{3 t}$ value found in the samples is not significantly lower than the highest $\mathrm{Fe}_{2} \mathrm{O}_{3 t}$ value found in the samples (Table IV). The difference between the high and low values of $\mathrm{Fe}_{2} \mathrm{O}_{3}$ obtained from this horizon appears to be significant and fairly large. One-tailed tests for significant differences in the concentrations of the other elements yield the results presented in Table $\mathrm{V}$, and show that given the above assumption there are significant differences between the high and low concentrations of all elements 
TABLE IV

SAMPLE ONE TAILED TEST FOR SIGINIFICANT

DIFFERENCES IN ELEMENTAL

CONCENTRATIONS

High $\mathrm{Fe}_{2} \mathrm{O}_{3 t}$ value: 14.4

Low $\mathrm{Fe}_{2} \mathrm{O}_{3 t}$ value: 7.4

Standard deviation of high value: 0.3

Confidence level: 958

$\mathrm{H}_{0}$ : The lower $\mathrm{Fe}_{2} \mathrm{O}_{3 t}$ value is not significantly lower than the higher $\mathrm{Fe}_{2} \mathrm{O}_{3 t}$ value.

The critical value is 1.645 standard deviations below the higher $\mathrm{Fe}_{2} \mathrm{O}_{3 t}$ value. If the lower $\mathrm{Fe}_{2} \mathrm{O}_{3 t}$ value is less than $13.9 \mathrm{H}_{0}$ can be rejected. Since 7.4 is less than 13.9 the lower $\mathrm{Fe}_{2} \mathrm{O}_{3 t}$ value is significantly lower than the higher $\mathrm{Fe}_{2} \mathrm{O}_{3 t}$ value. 


\section{TABLE V}

\section{HIGH AND LOW VALUES FOR CONCENTRATIONS DETERMINED IN INITIAL EXPERIMENT ON SAMPLES $27-4 \mathrm{~N}-1$ TO 10}

$\begin{array}{lllll}\text { ELEMENT } & \text { HIGH } & \text { LOW } & \text { ESTIMATED } & \text { SIGNIFICANT } \\ & \text { VALUE } & \text { VALUE } & \text { STANDARD } & \text { DIFFERENCE? } \\ & & & \text { DEVIATION } & \end{array}$

$\begin{array}{lllll}\mathrm{Sm} & 4.62 & 4.22 & 0.04 & \text { YES } \\ \mathrm{Sc} & 26.3 & 20.6 & 0.2 & \text { YES } \\ \mathrm{Yb} & 2.3 & 1.6 & 0.4 & \text { YES } \\ \mathrm{Cr} & 87.6 & 59 . & 7 . & \text { YES } \\ \mathrm{Co} & 20.3 & 10.3 & 1.4 & \text { YES } \\ \mathrm{La} & 33.8 & 31.0 & 0.4 & \text { YES } \\ \mathrm{Na}_{2} \mathrm{O} & 0.057 & 0.044 & 0.002 & \text { YES }\end{array}$

Estimated standard deviations are based on counting statistics.

$\mathrm{Na}_{2} \mathrm{O}$ value is in percent, all other values are in ppm. 958 confidence level. 


$$
\text { SS }_{w}=\sum_{j=1}^{m} \sum_{i=1}^{n} x_{i j}{ }^{2}-\sum_{j=1}^{m}\left(\left(\sum_{i=1}^{n} x_{i j}\right)^{2} / n\right)
$$

$$
S S_{a}=\sum_{i=1}^{m}\left(\left(\sum_{i=1}^{n} x_{i j}\right)^{2} / n\right)-\left(\sum_{i=1}^{m} \sum_{i=1}^{n} x_{i j}\right)^{2} / N
$$

$$
\text { SS } S_{i}=\sum_{i=1}^{m} \sum_{i=1}^{n} x_{i j}{ }^{2}-\left(\sum_{i=1}^{m} \sum_{i=1}^{n} x_{i j}\right)^{2} / N
$$

Figure 16. Formulae for the computation of the sum of the squares within replications, the sum of the squares among samples and the total sum of the squares. From Davis (1973). 
detected. This initial finding provided the impetus for further study.

A replication of trace element concentrations in samples $27-4 \mathrm{~N}-1$ to 9 made it possible to use the methods of Davis (1973) to determine the total variance, the variance between the two replications and the variance among the nine samples. If $\mathrm{m}$ is the number of samples, $\mathrm{n}$ is the number of replications and $\mathrm{N}$ is $\mathrm{m}$ times $\mathrm{n}$ then

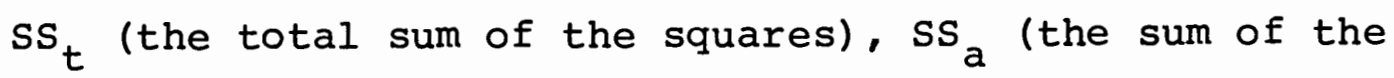
squares among samples) and $\mathrm{SS}_{\mathrm{W}}$ (the sum of the squares within replications) are given by the formulae in Figure 16. These results can be used to determine the total variance $\left(\mathrm{V}_{t}=S S_{t} /(\mathrm{N}-1)\right)$, the variance among samples $\left(V_{a}=S S_{a} /(m-1)\right)$ and the variance within replications $\left(V_{w}=S S_{w} /(N-m)\right)$ (Davis, 1973). Once these parameters are computed with the $F$ test statistic $\left(F=V_{a} / V_{w}\right)$ can be calculated and used to test the hypothesis that the variance among samples is significantly greater than the variance between replications. Table VI shows the total variance, the variance among samples, the variance within replications and the $\mathrm{F}$ test statistic for seven elements. The initial hypothesis of the $F$ test is that the two variances are not statistically different. This hypothesis is either rejected or not depending on whether or not the $\mathrm{F}$ test statistic is greater than a critical 


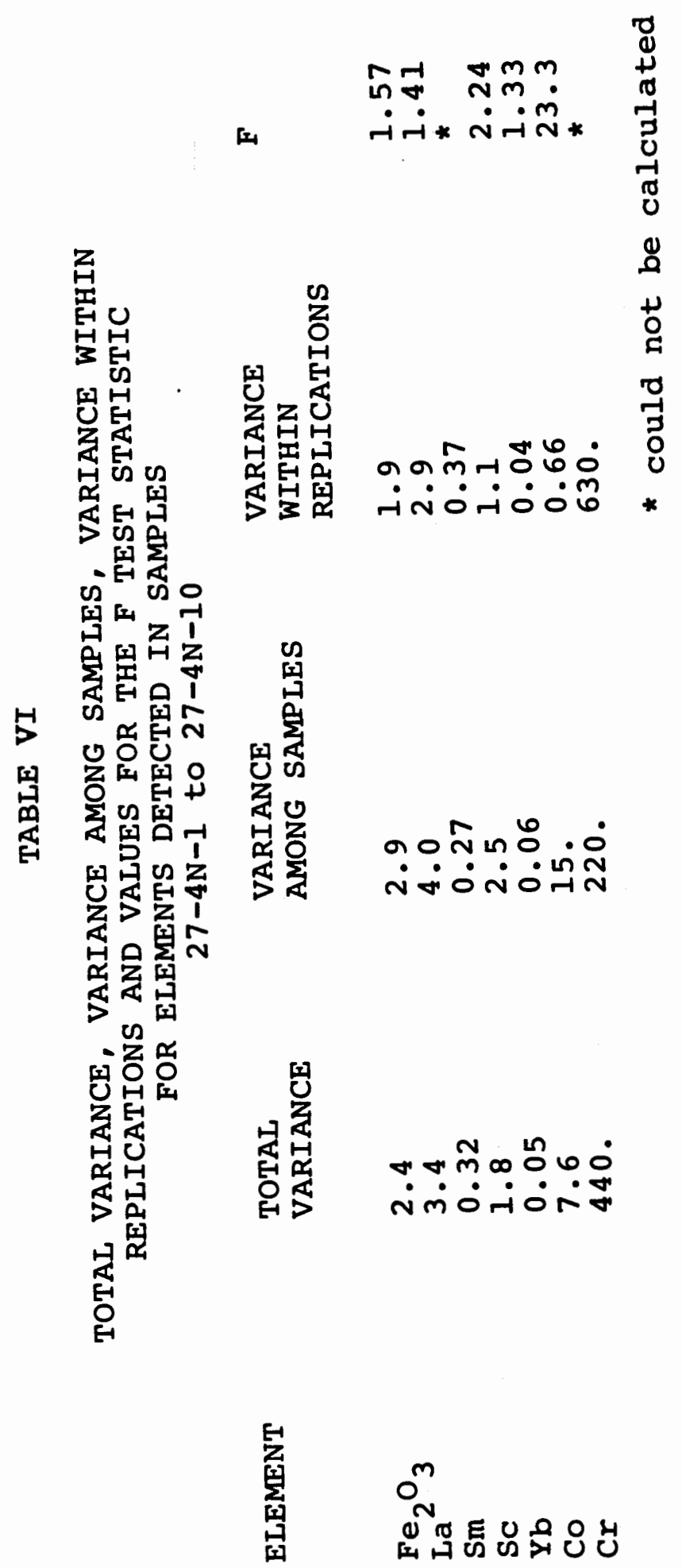


value (Davis, 1973). The variance among samples has $\mathrm{m}-1$ or in this case 8 degrees of freedom while the variance within replications has $\mathrm{N}-\mathrm{m}$ or in this case 9 degrees of freedom. When the numerator has 8 degrees of freedom and the denominator has 9 degrees of freedom the critical value of $F$ is $3.23(\alpha=0.05)$ (Mendenhall, 1975). By convention the $F$ test statistic is always greater than 1 so an $F$ test value of $V_{a} V_{w}$ could not be calculated for $\mathrm{Sm}$ and $\mathrm{Cr}$.

of the elements tested, only the value for co is greater than the critical value (Table VI). The variance among samples is significantly greater than the variance within replications for Co. For $\mathrm{Fe}, \mathrm{La}, \mathrm{Sm}, \mathrm{Sc}, \mathrm{Yb}$ and Cr the variance among samples is not significantly greater than the variance within replications. This means that for $\mathrm{Fe}, \mathrm{La}, \mathrm{Sm}, \mathrm{Sc}, \mathrm{Yb}$ and $\mathrm{Cr}$ experimental error is large enough to account for the variation in elemental concentrations between samples. The previously discussed one-tailed test showed significant differences between the high and low values for all of the elements detected. The probable reason for these apparently contradictory results is that the error determined by using counting statistics is less than the actual error associated with the determination of elemental concentrations. There are various possible sources for error above 
and beyond the counting error. Error in weighing the samples, inhomogeniety in the flux of the nuclear reactor and comparison of the samples to dissimilar standards in different runs must all be part of the greater error observed, and there are probably other sources for error. Errors in weighing should be negligible; on the order of 5 parts per 10,000 . The other two factors mentioned probably contribute the major portion of the added error. These factors probably are more important when comparing the results of two different runs than when comparing results within a single run; the samples in a single run are likely to be subject to the same inhomogenieties in flux and are all compared to the same standard. Intrarun error is, therefore, probably less than inter-run error.

Mean concentrations and standard deviations of 23 elements determined for the $27-4 \mathrm{~N}$ and 208 samples in experiments $7 \mathrm{~L}$ and $7 \mathrm{M}$ respectively are presented in Table VII. A maximum value for the error found within a given experiment can be assigned if it is assumed that all of the variability within the 208 and $27-4 \mathrm{~N}$ samples is due to experimental error, a worst case assumption. An intra-run error of approximately 108 for $\mathrm{Na}_{2} \mathrm{O}, \mathrm{La}$, $\mathrm{Sm}, \mathrm{Yb}, \mathrm{Lu}, \mathrm{Sc}, \mathrm{Th}, \mathrm{Fe}_{2} \mathrm{O}_{3 t}, \mathrm{Ta}, \mathrm{Tb}, \mathrm{Eu}, \mathrm{Hf}, \mathrm{Ce}, \mathrm{Cs}, \mathrm{Zn}$, $\mathrm{Ba}$ and $\mathrm{U}$, and somewhere near $20 \%$ for the other elements 


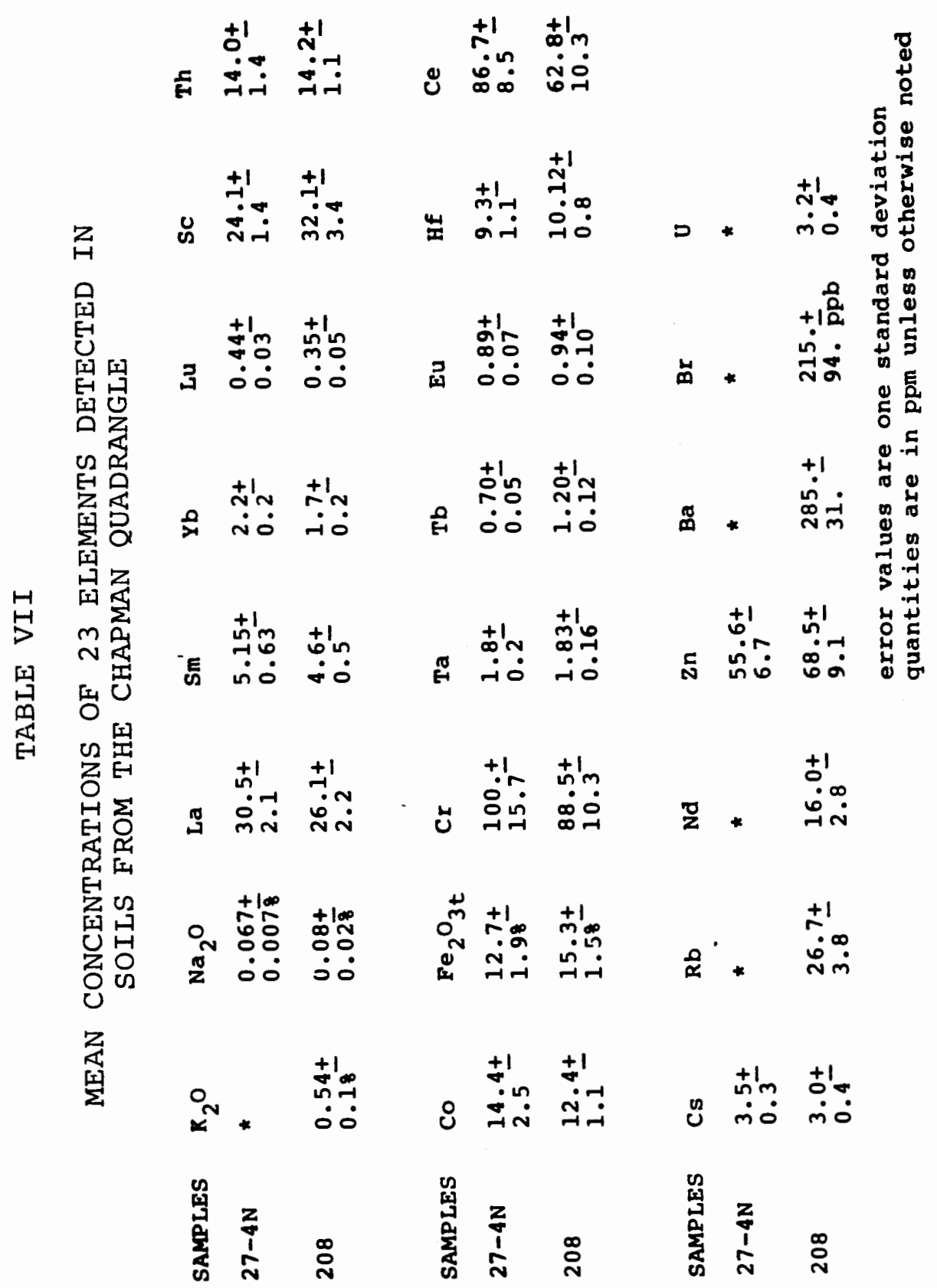


determined would account for the observed variation. Runs about the mean

The assumption that all the variability in these samples is due to experimental error is a worst case assumption. Some variation may be due to actual differences in the samples. The samples were tested using a test of runs about the mean value to see if a systematic pattern of variation could be detected in the samples. Each sample which has an elemental concentration greater than the mean value for all of the samples can be represented by $a+$, each sample with an elemental concentration less than the mean value can be represented by a - and samples which have elemental concentrations equal to the mean or in which the element was not detected can be represented by a zero. The ordered samples can be used to produce an ordered pattern: the $\mathrm{Fe}_{2} \mathrm{O}_{3 t}$ values for the first determination of concentrations in samples $27-4 \mathrm{~N}-1$ to 10 (Appendix B), for example, give a scheme of -+++-++--+. If a / is used to separate the runs the pattern becomes $-/+++/-1++/--1+$. There are six runs. Six $\mathrm{Fe}_{2} \mathrm{O}_{3 t}$ values are greater than the mean, and four $\mathrm{Fe}_{2} \mathrm{O}_{3 t}$ values are less than the mean. Critical values for the runs test are available for low numbers of runs (Owen, 1962), and show that, in this case, there are neither too many nor too few runs about the mean. The $\mathrm{Fe}_{2} \mathrm{O}_{3 t}$ in the outcrop 
appears to be randomly distributed $(\alpha=0.05)$. The results of tests of runs about the mean for the initial determination of concentrations in samples $27-4 \mathrm{~N}-1$ to 10 , the second determination of concentrations in samples 27-4N-1 to 9 and the determination of concentrations in samples $208-1$ to 20 are presented in Table VIII.

In the first determination of the 27-4N samples $\mathrm{Na}_{2} \mathrm{O}$ showed too few runs about the mean and none of the elements showed too many runs about the mean. The second determination of the $27-4 \mathrm{~N}$ samples showed too few runs about the mean for $\mathrm{Sm}, \mathrm{Th}, \mathrm{Eu}$ and $\mathrm{Ce}$. The results for $\mathrm{Na}_{2} \mathrm{O}$ and $\mathrm{Sm}$ are not duplicated in the two replications, suggesting that they are spurious. In the 208 samples, none of the elements have too many runs about the mean and only $\mathrm{K}_{2} \mathrm{O}$ has too few runs about the mean. Too few runs about the mean as seen in the $T h, E u$, and $C e$ of the 27-4N samples and the $\mathrm{K}_{2} \mathrm{O}$ of the 208 samples suggest that the elements are concentrated and depleted systematically in zones within the outcrop. The zones of concentration/depletion are necessarily larger than the distance between samples: $20 \mathrm{~cm}$ for the 27-4N samples and $60 \mathrm{~cm}$ for the 208 samples, or the zones would not have been detected. 


\section{TABLE VIII}

\section{TEST OF RUNS ABOUT \\ THE MEAN}

\begin{tabular}{|c|c|c|c|c|c|c|c|}
\hline $\begin{array}{l}\text { SAMPLE } \\
\text { NUMBERS }\end{array}$ & EXPERIMENT & ELEMENT & $\begin{array}{l}\text { NLMBER } \\
\text { OF RUNS }\end{array}$ & $\begin{array}{l}\text { NUMBER OF } \\
\text { CONCENTRA- } \\
\text { TIONS ABOVE } \\
\text { THE MEAN }\end{array}$ & $\begin{array}{l}\text { NUNBER OF } \\
\text { CONCENTRA- } \\
\text { TIONS ABOVE } \\
\text { THE MEAN }\end{array}$ & $\begin{array}{l}\text { TOO MANY } \\
\text { RUNS? }\end{array}$ & $\begin{array}{l}\text { TOO FEW } \\
\text { RUNS? }\end{array}$ \\
\hline $27-4 N-1$ to 10 & $\begin{array}{l}\text { INITIAL } \\
\text { DETERMIMATION }\end{array}$ & $\begin{array}{l}\mathrm{Fe}_{2} \mathrm{O}_{3 \mathrm{t}} \\
\mathrm{La} \mathrm{Sm} \\
\mathrm{Sc} \\
\mathrm{Yb} \\
\mathrm{Co} \\
\mathrm{Cr} \\
\mathrm{Na}_{2} \mathrm{O}\end{array}$ & $\begin{array}{l}6 \\
7 \\
7 \\
6 \\
7 \\
6 \\
7 \\
2\end{array}$ & $\begin{array}{l}7 \\
6 \\
6 \\
7 \\
4 \\
5 \\
5 \\
3\end{array}$ & $\begin{array}{l}3 \\
4 \\
4 \\
3 \\
6 \\
5 \\
5 \\
7\end{array}$ & $\begin{array}{l}\text { NO } \\
\text { NO } \\
\text { NO } \\
\text { NO } \\
\text { NO } \\
\text { NO } \\
\text { NO } \\
\text { NO }\end{array}$ & $\begin{array}{l}\text { NO } \\
\text { NO } \\
\text { MO } \\
\text { NO } \\
\text { NO } \\
\text { NO } \\
\text { NO } \\
\text { YES }\end{array}$ \\
\hline $27-4 N-1$ to 9 & $7 L$ & $\begin{array}{l}\mathrm{Na}_{2} \mathrm{O} \\
\mathrm{La} \\
\mathrm{Sm} \\
\mathrm{Yb} \\
\mathrm{Lu} \\
\mathrm{Sc} \\
\mathrm{Th} \\
\mathrm{Co} \\
\mathrm{Fe}_{2} \mathrm{O}_{3 \mathrm{t}} \\
\mathrm{Cr}^{2} \\
\mathrm{Ta} \\
\mathrm{Eu} \\
\mathrm{Hf} \\
\mathrm{Ce} \\
\mathrm{Cs} \\
\mathrm{Zn}\end{array}$ & $\begin{array}{l}6 \\
6 \\
8 \\
2 \\
5 \\
7 \\
8 \\
4 \\
5 \\
4 \\
6 \\
8 \\
6 \\
8 \\
3 \\
6\end{array}$ & $\begin{array}{l}5 \\
3 \\
5 \\
4 \\
5 \\
4 \\
5 \\
6 \\
3 \\
3 \\
4 \\
5 \\
5 \\
4 \\
5 \\
5\end{array}$ & $\begin{array}{l}4 \\
6 \\
4 \\
6 \\
3 \\
5 \\
4 \\
3 \\
6 \\
6 \\
4 \\
4 \\
3 \\
5 \\
4 \\
4\end{array}$ & $\begin{array}{l}\text { NO } \\
\text { NO } \\
\text { YES } \\
\text { NO } \\
\text { NO } \\
\text { NO } \\
\text { YES } \\
\text { NO } \\
\text { NO } \\
\text { NO } \\
\text { NO } \\
\text { YES } \\
\text { NO } \\
\text { YES } \\
\text { NO } \\
\text { NO }\end{array}$ & $\begin{array}{l}\text { NO } \\
\text { NO } \\
\text { NO } \\
\text { YES } \\
\text { NO } \\
\text { NO } \\
\text { NO } \\
\text { NO } \\
\text { NO } \\
\text { NO } \\
\text { NO } \\
\text { NO } \\
\text { NO } \\
\text { NO } \\
\text { NO } \\
\text { NO }\end{array}$ \\
\hline $208-1$ to 20 & 7m & $\begin{array}{l}K_{2} O_{0} \\
\mathrm{Na}_{2} \mathrm{O} \\
\mathrm{La} \\
\mathrm{Sm}_{\mathrm{Yb}} \\
\mathrm{Lu} \\
\mathrm{SC} \\
\mathrm{Th} \\
\mathrm{CO} \\
\mathrm{Fe}_{2} \mathrm{O}_{3 t} \\
\mathrm{Cr} \\
\mathrm{Ta} \\
\mathrm{Tb} \\
\mathrm{Eu} \\
\mathrm{Hf} \\
\mathrm{Ce} \\
\mathrm{Cs} \\
\mathrm{Rb} \\
\mathrm{Nd} \\
\mathrm{Zn} \\
\mathrm{U} \\
\mathrm{Br}\end{array}$ & $\begin{array}{l}4 \\
6 \\
12 \\
8 \\
9 \\
10 \\
8 \\
12 \\
9 \\
10 \\
13 \\
9 \\
12 \\
9 \\
13 \\
9 \\
11 \\
8 \\
7 \\
13 \\
8 \\
10\end{array}$ & $\begin{array}{l}10 \\
8 \\
8 \\
6 \\
8 \\
8 \\
7 \\
9 \\
8 \\
10 \\
9 \\
7 \\
10 \\
8 \\
8 \\
8 \\
6 \\
8 \\
8 \\
10 \\
9 \\
10\end{array}$ & $\begin{array}{l}7 \\
7 \\
11 \\
10 \\
10 \\
9 \\
13 \\
11 \\
12 \\
10 \\
11 \\
13 \\
10 \\
12 \\
12 \\
11 \\
11 \\
8 \\
9 \\
10 \\
10 \\
10\end{array}$ & $\begin{array}{l}\text { NO } \\
\text { NO } \\
\text { NO } \\
\text { NO } \\
\text { NO } \\
\text { NO } \\
\text { NO } \\
\text { NO } \\
\text { NO } \\
\text { NO } \\
\text { NO } \\
\text { NO } \\
\text { NO } \\
\text { HO } \\
\text { NO } \\
\text { NO } \\
\text { NO } \\
\text { NO } \\
\text { NO } \\
\text { NO } \\
\text { NO } \\
\text { NO }\end{array}$ & $\begin{array}{l}\text { YES } \\
\text { NO } \\
\text { NO } \\
\text { NO } \\
\text { NO } \\
\text { NO } \\
\text { NO } \\
\text { NO } \\
\text { NO } \\
\text { NO } \\
\text { NO } \\
\text { NO } \\
\text { NO } \\
\text { NO } \\
\text { NO } \\
\text { NO } \\
\text { NO } \\
\text { NO } \\
\text { NO } \\
\text { NO } \\
\text { NO } \\
\text { NO }\end{array}$ \\
\hline & & & & & \multicolumn{3}{|c|}{$\begin{array}{l}\text { Critical values from Owen (1962) } \\
95 \% \text { confidence level }\end{array}$} \\
\hline
\end{tabular}


Summary

Analysis of elemental concentrations using INAA is subject to errors which are greater than those assigned on the basis of counting statistics, and this experimental error is large enough to account for observed lateral inhomogenieties seen in laterite profiles. If it is assumed that all variability seen in serial samples of laterite taken from the same horizon is due to experimental error a maximum value for intra-run experimental error may be assigned. This value is about 108 for $\mathrm{Na}_{2} \mathrm{O}, \mathrm{La}$, $\mathrm{Sm}, \mathrm{Yb}, \mathrm{Lu}, \mathrm{Sc}, \mathrm{Th}, \mathrm{Fe}_{2} \mathrm{O}_{3 t}, \mathrm{Ta}, \mathrm{Tb}, \mathrm{Eu}, \mathrm{Hf}, \mathrm{Ce}, \mathrm{Cs}, \mathrm{Zn}$, $\mathrm{Ba}$ and $\mathrm{U}$ and near $20 \%$ for all other elements determined. Examination of serial samples using tests of runs about the mean shows little detected systematic depletion of elements.

\section{ENRICHMENT RATIOS}

Table IX presents ratios of elemental concentrations in weathered samples collected throughout the study area to concentrations of the same element present in fresh low Mgo Grande Ronde Basalt (Table I). These ratios are similar to the enrichment ratios employed by Gordon and others (1958) in their examination of the Arkansas bauxite region and Dennen and Norton (1977) in their study of the bauxites of the Amazon Basin. Samples were compared to values calculated for low Mgo Grande Ronde Basalt since 
this material is the parent for most of the weathered materials tested, and the concentrations of almost all elements detected are virtually identical in Frenchman Springs, low Mgo Grande Ronde and high MgO Grande Ronde Basalts. Concentrations used are those calculated from the first count of the samples unless the element in question was not detected in the first count. Samples of weathered pre-CRB sandstone (69-1 and 69-2) and a sample of post-CRB silt $(204-8)$ were also compared to low MgO Grande Ronde Basalt to emphasize the chemical differences between these materials and the weathered basalt samples. Gordon and others (1958) followed the work of Goldschmidt (1937) in trying to explain the behavior of elements during weathering by the differing charge densities of the ions formed by the elements in solution. Figure 17 plots size against charge for some of the most common ions. Gordon and others divided the diagram into three areas bounded by $l$ ines at $z / R=3.0$ and $z / R=12.0$. Elements which have a low ionic potential plot above and to the left of the $\mathrm{z} / \mathrm{R}=3.0$ line. These elements are thought to form basic oxides and should remain in 'true ionic solution' which allows them to be carried off and depleted during the weathering process. Between the $\mathrm{z} / \mathrm{R}=3.0$ and the $\mathrm{z} / \mathrm{R}=12.0$ lines the elements are viewed as being amphoteric and capable of acting as either acids or bases. These 


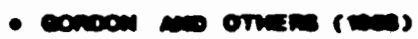

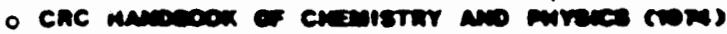

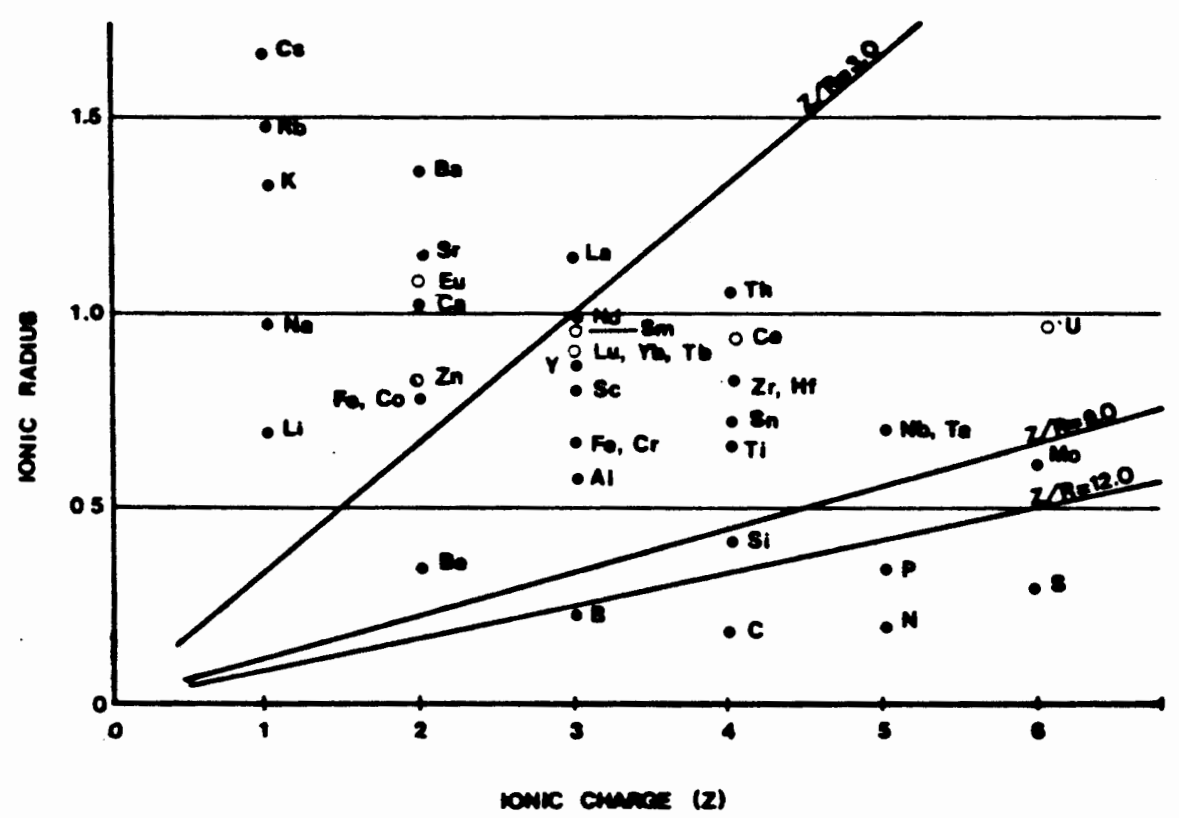

Figure 17. Cation size versus ionic charge. After Gordon and others (1958). 
elements form insoluble hydroxides with the portion of water molecules which are dissociated into $\mathrm{OH}^{-}$ions and should become enriched during weathering. Elements below the $\mathrm{z} / \mathrm{R}=12.0$ line have high charge to size ratios and tend to form complex ions with oxygen which are usually quite soluble (Gordon and others, 1958, Carroll, 1970b). This model for the behavior of elements during weathering is not entirely in accordance with the actual behavior of the elements during weathering. Gordon and others (1958) state that 'agreement is not complete... between the theoretical behavior of the elements as based on their ionic potential and their concentrations as determined...discrepancies concern principally beryllium, copper and chromium'. Dennen and Norton (1977) examined this model during their discussion of Amazon Basin bauxites and found that the theory did not adequately account for observed elemental behavior. They preferred an explanation of the relative solubilities and insolubilities of elements based on the abilities of the elements to be adsorbed on and absorbed in aluminum and iron hydroxides. The ionic potential theory of elemental solubility predicts that: $\mathrm{Cs}, \mathrm{Rb}, \mathrm{Na}, \mathrm{Br}, \mathrm{Sr}, \mathrm{Eu}, \mathrm{Zn}, \mathrm{Co}$ and La should form soluble ions and be removed; and $\mathrm{Nd}, \mathrm{Sm}, \mathrm{Lu}, \mathrm{Yb}$, $\mathrm{Tb}, \mathrm{Sc}, \mathrm{Fe} \mathrm{III}^{\mathrm{II}} \mathrm{Cr}, \mathrm{Ce}, \mathrm{Hf}, \mathrm{Th}$ and $\mathrm{Ta}$ should form insoluble hydroxides. The last three rows of Table IX 
TABLE IX

ENRICHMENT RATIOS FOR WEATHERED MATERIALS

\begin{tabular}{|c|c|c|c|c|c|c|c|c|c|c|}
\hline $\begin{array}{l}\text { SAMPLE } \\
\text { NULAER }\end{array}$ & $\begin{array}{l}\text { LOCATION } \\
\text { NUEBER }\end{array}$ & $\begin{array}{l}\text { MATERIAL } \\
\text { TESTED }\end{array}$ & $\mathrm{Na}_{2} \mathrm{O}$ & $a$ & $\sin$ & b b & Lu & c & $\mathrm{Th}$ & Co \\
\hline $\begin{array}{l}27-4 N \\
208 \\
69-1 \\
69-2 \\
69-3 \\
69-4 \\
69-5 \\
204-1 \\
204-2 \\
204-3 \\
204-4 \\
204-5 \\
204-6 \\
204-7 \\
204-8 \\
8-20-6 \\
8-28-6 \\
8-5-4 \\
8-18-6 \\
9-2-2 \\
10-15-1 \\
8-28-2 \\
8-20-4 \\
208-P T S I \\
208-H I S I \\
\text { PISB-28-2 } \\
\text { PIS } 27-4 N\end{array}$ & $\begin{array}{l}209 \\
208 \\
69 \\
69 \\
69 \\
69 \\
69 \\
204 \\
204 \\
204 \\
204 \\
204 \\
204 \\
204 \\
204 \\
57 \\
96 \\
4 \\
28 \\
107 \\
193 \\
91 \\
56 \\
208 \\
208 \\
100 \\
209\end{array}$ & $\begin{array}{l}\text { Bauxite } \\
\text { Bauxite } \\
\text { Sandstone } \\
\text { Sandstone } \\
\text { Bauxite } \\
\text { Weath rinde } \\
\text { Saproilte } \\
\text { Vein fillinge } \\
\text { Vein fillinge } \\
\text { Saprolite } \\
\text { Bauxite } \\
\text { Bauxite } \\
\text { Bauxite } \\
\text { Bauxite } \\
\text { Loess } \\
\text { Saprolite } \\
\text { Bauxite } \\
\text { Saprolite } \\
\text { Saprolite } \\
\text { Saprolite } \\
\text { Saprolite } \\
\text { Bauxite } \\
\text { Saprolite } \\
\text { Bog irone } \\
\text { Bog irone } \\
\text { Pisolites } \\
\text { Pisolites }\end{array}$ & $\begin{array}{l}0.02 \\
0.03 \\
0.01 \\
0.01 \\
0.02 \\
0.01 \\
: \\
0.01 \\
0.01 \\
0.02 \\
0.02 \\
0.02 \\
0.02 \\
0.35 \\
0.01 \\
0.34 \\
0.02 \\
0.01 \\
0.01 \\
0.003 \\
0.02 \\
0.01 \\
0.01 \\
0 \\
0.01 \\
0.003\end{array}$ & $\begin{array}{l}1.2 \\
1.1 \\
1.5 \\
1.7 \\
0.85 \\
0.16 \\
0.87 \\
6.0 \\
11.4 \\
1.53 \\
1.1 \\
1.2 \\
1.3 \\
1.2 \\
1.7 \\
0.20 \\
1.06 \\
0.95 \\
0.11 \\
1.08 \\
0.39 \\
1.08 \\
1.59 \\
0.34 \\
0.20 \\
0.23 \\
0.31\end{array}$ & $\begin{array}{l}0.83 \\
0.85 \\
0.81 \\
0.71 \\
0.57 \\
0.23 \\
0.69 \\
1.63 \\
3.1 \\
0.58 \\
0.74 \\
0.80 \\
0.76 \\
0.71 \\
1.2 \\
0.29 \\
0.58 \\
1.09 \\
0.61 \\
1.14 \\
0.74 \\
0.77 \\
2.03 \\
0.36 \\
0.13 \\
0.29 \\
0.33\end{array}$ & $\begin{array}{l}0.83 \\
0.45 \\
0.67 \\
0.64 \\
0.50 \\
0.53 \\
0.81 \\
0.42 \\
0.74 \\
0.75 \\
0.66 \\
0.70 \\
0.90 \\
0.36 \\
0.58 \\
0.85 \\
0.79 \\
0.98 \\
0.61 \\
0.45 \\
1.43 \\
0.26 \\
0.25 \\
0.15 \\
0.35\end{array}$ & $\begin{array}{l}0.73 \\
0.56 \\
0.67 \\
0.64 \\
0.52 \\
0.57 \\
0.62 \\
0.10 \\
0.72 \\
0.78 \\
0.57 \\
0.62 \\
0.88 \\
0.52 \\
0.64 \\
0.67 \\
0.70 \\
0.98 \\
0.51 \\
0.56 \\
1.24 \\
0.44 \\
0.30 \\
0.38 \\
0\end{array}$ & $\begin{array}{l}0.77 \\
0.90 \\
0.67 \\
0.64 \\
0.72 \\
3.06 \\
1.64 \\
0.48 \\
1.48 \\
1.43 \\
0.81 \\
0.76 \\
0.78 \\
0.73 \\
0.56 \\
1.96 \\
1.03 \\
1.26 \\
2.00 \\
2.03 \\
1.63 \\
1.18 \\
1.29 \\
1.21 \\
0.62 \\
0.75\end{array}$ & $\begin{array}{l}2.59 \\
3.09 \\
2.77 \\
2.34 \\
2.52 \\
2.63 \\
1.66 \\
0.30 \\
1.41 \\
1.50 \\
2.91 \\
2.65 \\
2.57 \\
2.30 \\
2.39 \\
1.96 \\
2.57 \\
1.91 \\
1.63 \\
2.37 \\
1.26 \\
2.89 \\
1.78 \\
4.20 \\
2.46 \\
7.83 \\
6.86\end{array}$ & $\begin{array}{l}0.35 \\
0.22 \\
0.10 \\
0.07 \\
0.17 \\
2.81 \\
0.47 \\
0.18 \\
0.60 \\
0.19 \\
0.25 \\
0.21 \\
0.29 \\
0.46 \\
0.40 \\
1.24 \\
0.20 \\
1.18 \\
3.42 \\
0.55 \\
1.26 \\
0.27 \\
0.69 \\
0.114 \\
0.08 \\
0.16 \\
0.57\end{array}$ \\
\hline \multicolumn{3}{|c|}{$\begin{array}{l}\text { AVERAGE VALUES } \\
\text { Saprolite } \\
\text { Bauxite } \\
\text { Pisolites }\end{array}$} & $\begin{array}{l}0.01 \\
0.02 \\
0.01\end{array}$ & $\begin{array}{l}0.88 \\
1.13 \\
0.27\end{array}$ & $\begin{array}{l}0.90 \\
0.73 \\
0.31\end{array}$ & $\begin{array}{l}0.75 \\
0.61 \\
0.35\end{array}$ & $\begin{array}{l}0.70 \\
0.63 \\
0.39\end{array}$ & $\begin{array}{l}1.65 \\
0.85 \\
1.06\end{array}$ & $\begin{array}{l}1.76 \\
2.68 \\
7.35\end{array}$ & $\begin{array}{l}1.13 \\
0.27 \\
0.37\end{array}$ \\
\hline
\end{tabular}

\begin{tabular}{|c|c|c|c|c|c|c|c|c|c|c|c|c|}
\hline UMBI & $e_{2} \mathrm{O}_{3}$ & Cr & Ta & $\mathrm{bb}$ & $u$ & e & $\mathbf{E}$ & C8 & 10 & Id & ת & Ba \\
\hline $\begin{array}{l}08 \\
9-1 \\
9-2 \\
9-3 \\
9-4 \\
9-5 \\
04-1 \\
04-2 \\
04-3 \\
04-4 \\
04-5 \\
04-6 \\
04-7 \\
04-8 \\
-20-6 \\
-28-6 \\
-5-4 \\
-18-6 \\
-2-2 \\
0-15-1 \\
-28-2 \\
-20-4 \\
08-P T S I \\
08-H I S I \\
I S B-28-2\end{array}$ & $\begin{array}{l}1.3 \\
0.5 \\
0.4 \\
1.1 \\
2.2 \\
1.2 \\
0.3\end{array}$ & $\begin{array}{l}7.41 \\
5.75 \\
2.69 \\
3.52 \\
7.43 \\
3.68 \\
2.51 \\
6.51 \\
2.05 \\
7.54 \\
6.65 \\
5.90 \\
6.02 \\
8.09 \\
4.96 \\
3.44 \\
1.01 \\
1.26 \\
1.17 \\
6.69 \\
5.08 \\
1.04 \\
13.2\end{array}$ & $\begin{array}{l}2.09 \\
2.13 \\
1.27 \\
1.79 \\
1.84 \\
2.29 \\
1.81 \\
0.52 \\
2.11 \\
2.08 \\
2.24 \\
2.21 \\
2.08 \\
1.85 \\
2.08 \\
1.86 \\
1.47 \\
1.64 \\
1.62 \\
1.86 \\
1.42 \\
2.16 \\
1.42 \\
2.41\end{array}$ & $\begin{array}{l}0.75 \\
1.25 \\
0.68 \\
0.69 \\
2.48 \\
0.55 \\
0.49 \\
0.90 \\
0.74 \\
0.65 \\
0.71 \\
0.67 \\
0.54 \\
0.97 \\
1.11 \\
1.01 \\
1.23 \\
0.93 \\
1.14 \\
0.73 \\
0.97 \\
1.85 \\
1.27\end{array}$ & $\begin{array}{l}2 . \\
0 . \\
0 . \\
0 . \\
0 . \\
0 . \\
0 . \\
0 . \\
0 . \\
0 . \\
0 . \\
1 . \\
0 . \\
0 . \\
1 . \\
0 . \\
0 .\end{array}$ & $\begin{array}{l}2 . \\
1 . \\
1 . \\
1 . \\
1 . \\
1 . \\
0 . \\
1 . \\
0 .\end{array}$ & $\begin{array}{l}3 \\
3 \\
8 \\
3 \\
8 \\
8 \\
1 \\
2 \\
5 \\
3 \\
9 \\
5 \\
5 \\
7 \\
0 \\
5 \\
1\end{array}$ & $\begin{array}{l}2.59 \\
3.71 \\
2.54 \\
2.53 \\
: \\
: \\
: \\
3.45 \\
3.96 \\
3.15 \\
3.80 \\
2.83 \\
2.01 \\
* \\
* \\
* \\
0 \\
0.82 \\
1.60 \\
*\end{array}$ & 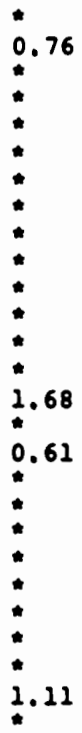 & $\begin{array}{l}: 0.51 \\
: \\
: \\
: \\
: \\
: \\
: \\
: \\
7.27 \\
: \\
: \\
: \\
: \\
: 07 \\
:\end{array}$ & $\begin{array}{l}1 . \\
0 . \\
1 . \\
* \\
*\end{array}$ & $\begin{array}{l}: .77 \\
: \\
: \\
: \\
: \\
: .57 \\
: \\
2.04 \\
: \\
2.95 \\
1.94 \\
2.41 \\
3.60 \\
: \\
:\end{array}$ \\
\hline
\end{tabular}

\section{AVERAGE VALUES}

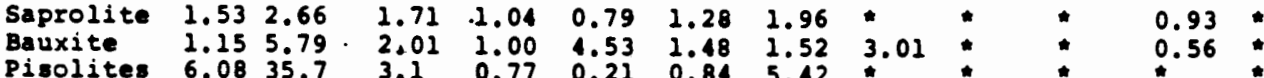

$$
\text { Pisolites } 6.08 \quad 35.7 \quad 3.1 \quad 0.77 \quad 0.21 \quad 0.84 \quad 5.12 \quad * \quad * \quad * \text { * }
$$

* not detected 0 excluded from summary table 
show the average enrichment factors for samples identified as saprolite, ferruginous bauxite and pisolites in the field. The values for the average saprolite are based on eight samples collected from locations throughout the Chapman Quadrangle. These samples were at various stages of weathering, but all preserved the original structure of the basalt to some degree and are assumed to represent, on the average, a somewhat lesser amount of weathering than the samples of ferruginous bauxite. Ferruginous bauxite samples were also collected from throughout the study area, and are similar in appearance to materials sampled by Libbey and others (1945) which were analyzed and shown to be ferruginous bauxite. The ferruginous bauxite samples are assumed to represent a more advanced state of weathering than the saprolite samples. They are devoid of the pre-weathering structure of the basalt and many contain secondary structures, such as pisolites. Samples of bauxite from site 204 represent 4 of the 8 samples which were used in computing the average value for bauxite. This obviously caused some bias in the value obtained, but this is of little significance since concentration values are similar in all ferruginous bauxite samples tested. Saprolite samples show anomalous average weak enrichment in Co, and average depletion of $\mathrm{Sm}, \mathrm{Lu}$ and $\mathrm{Yb}$, while the ferruginous bauxite samples show anomalous 
enrichment in $\mathrm{Cr}$ and $\mathrm{La}$ and depletion in $\mathrm{Sm}, \mathrm{Lu}, \mathrm{Yb}$ and Sc. The behavior of these elements runs counter to that predicted by the ionic potential model. The qualitative enrichment or depletion of non-listed elements in both the saprolite and the ferruginous bauxite were, on the other hand, predicted successfully by the ionic potential model for solubility of ions. The model does not, however, predict the magnitude of enrichment of $\mathrm{Cr}$ seen in both the saprolite and the ferruginous bauxite samples.

Samples 208-1 to $20,8-28-6$ and $8-28-2$ all show $\mathrm{K}_{2} \mathrm{O}$ concentrations near $0.5 \%$. The average $\mathrm{k}_{2} \mathrm{O}$ concentration in low Mgo Grande Ronde Basalt is approximately 1.88 (Wright and others, 1973, Swanson and others, 1979, Bentley and others, 1980, Hoffman, 1981). This means that over one quarter of the original $\mathrm{k}_{2} \mathrm{O}$ remains in or has been reintroduced to these ferruginous bauxite samples. The average analyzed $\mathrm{Na}_{2} \mathrm{O}$ concentration in these samples is near $0.1 \%$ and represents only a thirtyth of the original $\mathrm{Na}_{2} \mathrm{O}$. This runs counter to the ionic potential model which predicts that $\mathrm{K}^{+}$ion should go into solution and remain in solution much more easily than the $\mathrm{Na}^{+}$ion. The $\mathrm{K}^{+}$ion is probably sorbed on or in some mineral or mineraloid which occurs in the ferruginous bauxite.

The ionic potential theory of elemental solubility fails to predict the observed behavior of many elements 
in the saprolite and ferruginous bauxite samples collected from the study area. A model similar to that proposed by Dennen and Norton (1977) is, therefore, preferred for the behavior of elements during weathering. The mobility of ions during weathering is a function of their solubilities in hydrous solutions, which is in part controlled by their ionic potentials, and of the sorbtive properties of the ions on/in the solid materials present in the environment. Figure 18 shows some of the reactions and some of the equilibria which must be considered when a soluble metal ion is in equilibrium with sorbtive materials. The actual situation in weathering profiles is even more complex because of the presence of various materials including iron hydroxides, aluminum hydroxides, kandite clays, smectite clays and organic materials on which ions can be sorbed.

\section{CHEMISTRY OF PISOLITES}

The average enrichment values for pisolites shown in Table IX are based on two samples of high-iron pisolites separated mechanically from soil samples collected in the study area. Jackson (1974) found similar iron-rich pisolites from Wahkiakum County, Washington to be enriched in $\mathrm{Fe}_{2} \mathrm{O}_{3}, \mathrm{Lu}, \mathrm{Yb}, \mathrm{Th}$ and $\mathrm{Cr}$ and depleted in $\mathrm{Na}, \mathrm{Sc}, \mathrm{Hf}$, Co and La (Jackson, 1974). The average concentration values for pisolites analyzed in this study show strong enrichment 
$\left.M\left(\mathrm{H}_{2} \mathrm{O}\right)_{0}^{\mathrm{n}+} \stackrel{\mathrm{K}_{1}^{\mathrm{eds}}}{=} \mathrm{M(H}_{2} \mathrm{O}\right)_{6}^{\mathrm{n+}}$

$$
\int k_{1}, 0+x^{k_{1}}, x^{-}
$$

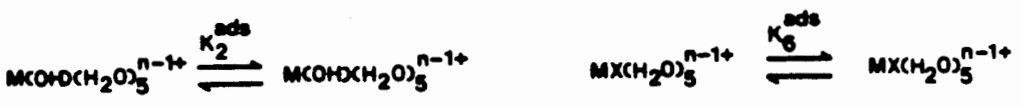

$$
\begin{aligned}
& \int \mid K_{2}, \text { OH }^{-} \quad \int K_{2}, x^{-}
\end{aligned}
$$

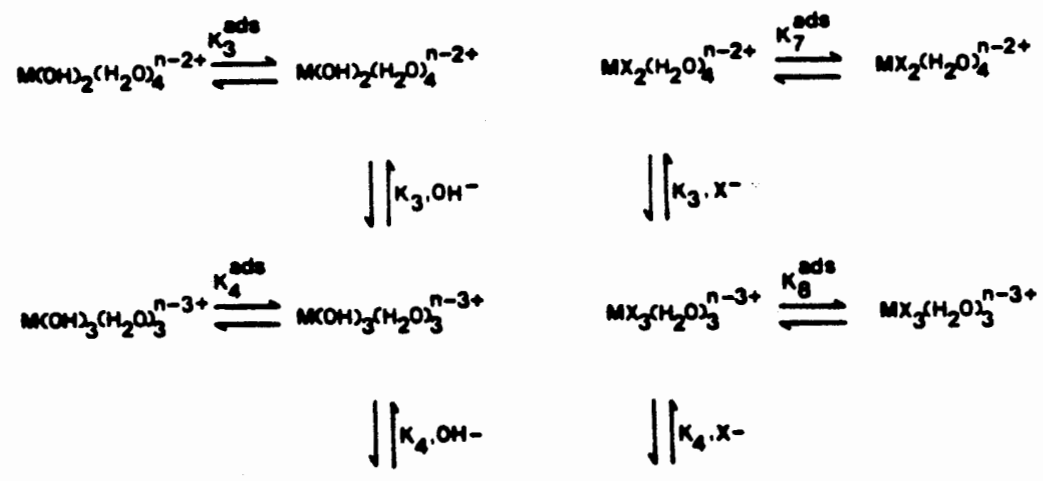

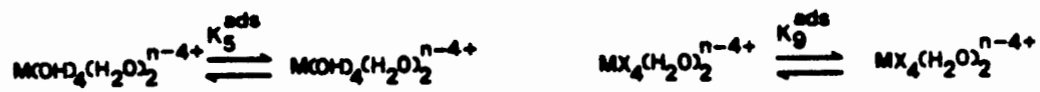

-tc.

Figure 18. Matrix of competing reactions involving aqua, hydroxide and other ligand (X) complexes in solution and sorbed onto a surface. Modified from Leckie and James (1974). 
in $\mathrm{Fe}_{2} \mathrm{O}_{3 t^{\prime}} \mathrm{Cr}, \mathrm{Ta}, \mathrm{Th}$ and $\mathrm{Hf}$, weak enrichment in Sc and slight to high depletion in all other detected elements (Table IX). The reason for the differing behavior of $\mathrm{Hf}$, $\mathrm{Sc}, \mathrm{Lu}$ and $\mathrm{Yb}$ in the pisolites from the two different areas is uncertain, but the strong enrichment of $\mathrm{Cr}$ and strong depletion of co seen in both studies is significant. $\mathrm{Cr}$ can form either $\mathrm{Cr}^{+3}$ or $\mathrm{CrO}_{4}^{-2}$ ions in solution. $\mathrm{CrO}_{4}^{-2}$ ions are quite soluble and any $\mathrm{Cr}$ found in weathered materials is probably in the +3 form. The radius of the $\mathrm{Cr}^{+3}$ ion is $0.63 \AA$ (CRC Handbook of Chemistry and Physics, 1974) which should make it preferred over $\mathrm{Fe}^{+3}$ (0.64 $\AA$ radius) in minerals or mineraloids which contain $\mathrm{Fe}^{+3}$. Cr has an enrichment factor in pisolites of 35.7; significantly higher than the enrichment factor for $\mathrm{Fe}_{2} \mathrm{O}_{3 t}$ ' suggesting that $\mathrm{Cr}$ is substituting for $\mathrm{Fe}^{+3}$ in the pisolites. Cr values for pisolites are much higher than the $\mathrm{Cr}$ values of the basalt from which ferruginous bauxite is derived, and it may be possible for $\mathrm{Cr}$ to be recovered as a byproduct of ferruginous bauxite mining. The $C r$ value of the pisolites is, however, quite low and any economic significance is doubtful.

Co can form either +2 or +3 ions in solution, but $\mathrm{Co}^{+2}$ is the stable form under most conditions (Dickerson and others, 1974, Helsop and Robinson, 1967). $\mathrm{Co}^{+2}$ has a radius of $0.72 \AA$ which should make it preferred 
over $\mathrm{Fe}^{+2}$ (0.74 $\AA$ radius) in minerals and mineraloids containing $\mathrm{Fe}^{+2}$. Low amounts of Co are present in pisolites and suggest that $\mathrm{Fe}^{+2}$ is low in pisolites. This in turn suggests that $\mathrm{Fe}^{+3}$ is the major form of iron in pisolites.

Previous discussion has shown that pisolites are formed authigenically probably under slightly acidic $\mathrm{pH}$ conditions. The high concentrations of iron as $\mathrm{Fe}^{+3}$ in pisolites suggest that iron probably migrated through the weathered materials to selected loci to form pisolites. The iron probably traveled in solution as $\mathrm{Fe}^{+2}$ since $\mathrm{Fe}^{+3}$ ions are significantly soluble only at very low $\mathrm{pH}$ values. Iron was probably oxidized from the +2 form to the +3 form during pisolite formation. This supports a model which postulated that the presence of oxidizing conditions controlled the origin of pisolites. The entire pisolitic zone was probably oxidizing at least periodically and pisolite formation may have been controlled in the pisolitic zone by the availability of nucleation sites. The boundary between the pisolitic ferruginous bauxite and the underlying pisolite free zones may be controlled by the downward extent of oxidizing conditions. 
FRACTIONATION OF LANTHANIDE ELEMENTS DURING WEATHERING Jackson (1974) noted that lanthanide group elements, numbers 57 to 71 in the periodic table, become fractionated during weathering. A portion of the present study was devoted to confirming this result and producing a model to explain this finding. Of elements 57 to 71 , La, Ce, Nd, Sm, Eu, Tb, Yb and Lu can be detected using INAA. Enrichment ratios for these lanthanides calculated for samples of weathered materials from the study area are shown in Table IX. Enrichment ratios for La, Sm, Lu and Ce were also calculated for samples of weathered materials collected in the Salem Hills by C.W. Hoffman (1981) and these are presented as Table $\mathrm{x}$. $\mathrm{Eu}$ and $\mathrm{Ce}$ are the most depleted and most enriched of the lanthanides respectively. Eu and Ce are also exceptions to the general rule that lanthanides occur as trivalent ions in solution, and can form $\mathrm{Eu}^{+2}$ and $\mathrm{Ce}^{+4}$ ions respectively as well as the usual trivalent ions. Divalent, trivalent and quadravalent ions behave quite differently even if the parent atoms are of approximately the same size. Under the conditions of Eh which were present during the formation of ferruginous bauxite deposits it is reasonable to assume that most of the $\mathrm{Ce}$ in the material was as $\mathrm{Ce}^{+4}$, and the insolubility of the medium sized +4 ions formed by Ce easily accounts for the observed 


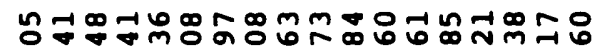

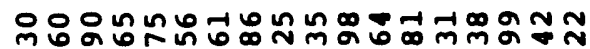

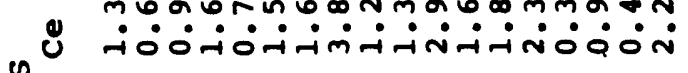
资

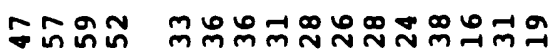
द्व 0000 00000000000.

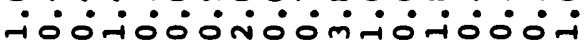

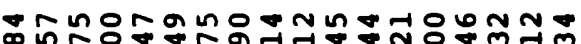
๑ -

nonotrom MO unamtrom

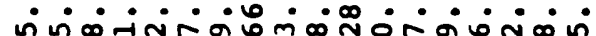

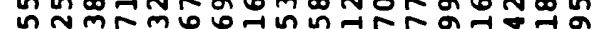

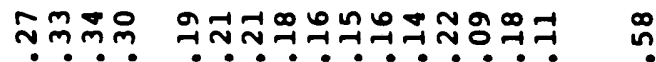

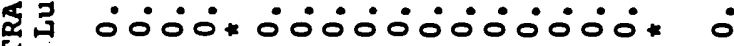

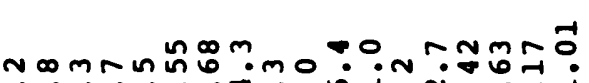

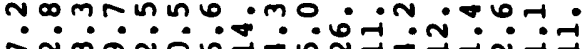

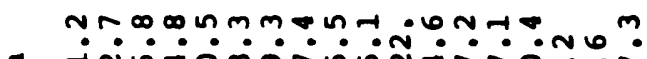

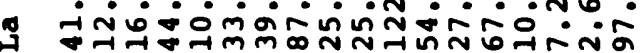

국ำ m m

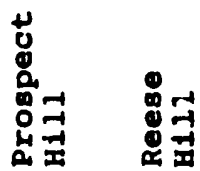

\section{:} 1 ดm N め

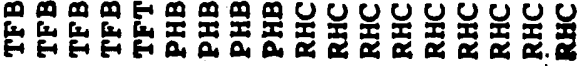


enrichment factor for Ce.

The strong depletion of $\mathrm{Eu}$ in the weathered samples tested cannot, however, be explained by the formation of $\mathrm{Eu}^{+2}$ ions during weathering. The standard ionization potential for the reaction $\mathrm{Eu}^{+2} \rightleftharpoons \mathrm{Eu}^{+3}+\mathrm{e}^{-}$is approximately equal to that for the reaction $\mathrm{Fe}^{+2} \rightleftharpoons \mathrm{Fe}^{+3}+\mathrm{e}^{-}$ (CRC Handbook of Chemistry and Physics, 1974). $\mathrm{Fe}^{+3}$ is the dominant form of $\mathrm{Fe}$ in ferruginous bauxite deposits and it should, therefore, be expected that the dominant form of Eu would be $\mathrm{Eu}^{+3}$. The anomalous behavior of $\mathrm{Eu}$ may instead be a function of fractionation during the igneous process which produced the CRB from which the ferruginous bauxite deposits were derived. In CRB, Eu tends to be concentrated in plagioclase feldspar laths while the other lanthanide group elements are concentrated in the glassy matrix of the basalt (M.H. Beeson, personal communication, 1983). The plagioclase weathers at a different rate than the glass matrix, and the observed differences in enrichment values may be a result of this difference. The minerals on or in which the other lanthanides are sorbed may not have been present or may not have been forming when $\mathrm{Eu}^{+3}$ ions were available in solution, and the $\mathrm{Eu}^{+3}$ ions may consequently have been carried out of the system. 
Differences in charge of ions formed or in the original position of the parent ions are probably sufficient to explain the observed fractionation of $\mathrm{Ce}$ and $\mathrm{Eu}$, but the other lanthanide group elements are quite similar to one another in the ions they produce, and all reside in the same original position within the CRB. These ions still, however, exhibit trends during weathering. Jackson (1974) noted that the ratios of $\mathrm{La} / \mathrm{Sm}$, $\mathrm{Sm} / \mathrm{Lu}$ and $\mathrm{La} / \mathrm{Lu}$ were higher in fresh basalt than they were in ferruginous bauxite, indicating that $\mathrm{La}^{+3}$ is more readily removed from the system than $\mathrm{Sm}^{+3}$ which is in turn more readily removed than $\mathrm{Lu}^{+3}$ during weathering. Analysis of weathered samples for the present study, on the other hand, show that La generally has a larger enrichment factor than Sm which in turn has a higher enrichment factor than $\mathrm{Lu}$. $\mathrm{Yb}$, which is next to $\mathrm{Lu}$ in the periodic table, has a low enrichment factor similar to the value for Lu. Nd, which lies between La and Sm in the periodic table, tends to have enrichment factors intermediate between $\mathrm{La}$ and $\mathrm{Sm}$. These results are exactly the reverse of those obtained by Jackson (1974), but are the same as those calculated from the data of C.W. Hoffman for samples from the Salem Hills (Table $\mathrm{X}$ ). It is, therefore, suggested that Jackson's results may be in error.

All lanthanides except $\mathrm{Ce}$ and Eu favor the +3 valence to the exclusion of all others. The fractionation 
trends seen in data from the present study and in data collected in the Salem Hills show that the larger trivalent lanthanide ions are less soluble than smaller trivalent lanthanide ions. In chemistry laboratories columns of ion exchange resins are used to separate trivalent lanthanide ions. The ions are sorbed onto ion exchange resins and the ions which are most weakly sorbed are eluted from the column first while more strongly sorbed ions are eluted later. Similar sorbtive interactions are known to occur in soils and it is suggested that a similar mechanism may be producing the observed fractionation of trivalent lanthanide ions.

Thin layers of soil are commonly used as stationary phases for chromatography in a technique called soil thin layer chromatography (STLC). This technique was first performed to study the behavior of pesticides in soils (Helling and Turner, 1968, Helling, 1971), but the retention of anions by soils has since become an area of interest (Nishita and others, 1978, Moreira-Nordeman, 1979, Balogh and Grigal, 1980). The anions which are of greatest interest are the radioactive decay products of nuclear fission. No work has been done on the lanthanides, but it is suggested that the use of the techniques outlined in the above-mentioned works might provide useful results. 
Iron oxide, aluminum oxide, clays and organic materials are all capable of ion exchange with surrounding pore waters and can all be analogous to the ion exchange resins used to separate lanthanides in the laboratory. Balogh and Grigal (1980) found that the anion exchange associated with clays and hydrous oxides is very weak and that the sorption of anions on organic matter appeared to be responsible for most of the observed separation of elements. There may be a significant amount of organic material present in the ferruginous bauxite samples analyzed, but the retention of the original basalt structure by saprolite samples suggests low organic content. The fractionation of trivalent lanthanides follows the same trend in saprolite samples and ferrugionus bauxite samples suggesting that organic material is not chiefly responsible for the sorptive reactions producing the lanthanide fractionation.

Pisolites which are very high in iron hydroxides have reversed trends of lanthanide fractionation with small lanthanides being enriched relative to large lanthanides. This suggests that iron oxides are, also, not the chief sorbtive agents producing fractionation. It is suggested that the high ion exchange capabilities associated with clays make them the most likely loci for lanthanide sorbtion although the role of aluminum oxides 
and hydroxides in these reactions cannot be assessed by the present study. 


\section{CHAPTER VI}

\section{CONCLUSIONS}

The ferruginous bauxite deposits of the study area are found over all flow groups of the CRB mapped in the study area. The association between ferruginous bauxite deposits and specific flows of Wanapum Basalt seen in the Salem Hills is not found in the Chapman Quadrangle. Ferruginous bauxite does not appear to be correlative to any specific CRB Group flow. There appears, instead, to be a correlation between ferruginous bauxite deposits and zones of faulting and shearing. This correlation may be due to an increase in permeability of the CRB units caused by shearing and also perhaps to an increase in the cumulative surface area exposed to weathering resultant from the grinding associated with faulting. As in the Salem Hills there appears to be an association between the groundwater pathway and the formation of ferruginous bauxite.

Smectite, metahalloysite and kaolinite were identified from samples of saprolite and ferruginous bauxite collected in the study area. The presence of these three minerals suggests that the fluids which formed ferruginous bauxite profiles were slightly acid, and were probably quite similar to present groundwater in the study area. 
The assemblage quartz, kaolinite, gibbsite is not a stable assemblage and its presence in pisolitic zone ferruginous bauxite probably reflects a change in weathering conditions during ferruginous bauxite formation. The mantling of quartz by iron hydroxides and oxides is probably responsible for allowing this apparently unstable assemblage to exist. Evidence from field study, laboratory investigation and literature search suggests that pisolitic zone ferruginous bauxite formed as a result of authigenic processes and not from fluvial or aeolian stratification of weathered materials. No evidence was found to indicate fluvial reworking of the pisolitic zone in the Chapman Quadrangle as proposed by Jackson (1974).

Geochemical investigation of ferruginous bauxite deposits of the study area show that the variation seen within a given horizon of a ferruginous bauxite deposit can be accounted for by experimental error, and is much less than the vertical differences detected within ferruginous bauxite deposits by Hoffman (1981). Systematic sampling of weathered basalt profiles has shown possible zones of high alkali concentrations $\left(\mathrm{K}_{2} \mathrm{O}\right)$ within some deposits. Other elements appear to be randomly distributed at the resolution used for this study. $\mathrm{Fe}^{+3}$ is the predominant form of iron leached from the deposits as $\mathrm{Fe}^{+2}$ during the transformation of basalt to saprolite 
to ferruginous bauxite.

The lanthanide elements are fractionated during weathering. Observed depletion trends suggest: that Ce formed $\mathrm{Ce}^{+4}$ during weathering and avoided leaching; that the strong depletion of $\mathrm{Eu}$ is due to its concentration in plagioclase during CRB formation and its depletion from the glass containing the other lanthanides; and that the other lanthanide group elements were leached from the basalt as $\mathrm{Ln}^{+3}$ ions. The trivalent lanthanides are fractionated during weathering. This is probably caused by their differing sorbtive strengths on materials found in the weathering environment. The clays which form during weathering are probably responsible for most of the sorbtive reactions. Large, low atomic number trivalent lanthanides are more weakly leached than the small, high atomic number trivalent lanthanides. 


\section{REFERENCES CITED}

Addicott, W.0., 1969, Tertiary climatic change in the marginal northeast Pacific Ocean: Science, v. 165, pp. 583-586.

Allen, V.T., 1948, Formation of bauxite from basaltic rocks of Oregon: Economic Geology, v. 43, pp. 619-626.

Baldwin, E.M., 1981, Geology of Oregon: Dubuque, Iowa, Kendall/Hunt Company, $170 \mathrm{p}$.

Balogh and Grigal, 1980, Soil chromatographic movement of Technetium-99 through selected Minnesota soils: Soil Science, v. 130, pp. 278-282.

Beeson, M.H. and Moran, M.R., 1979, Columbia River Basalt Group stratigraphy in western Oregon: Oregon Geology, v. 41, pp.11-14.

Beeson, M.H., 1982, personal communication.

Beeson, M.H., 1983, personal communication.

Bentley, R., Anderson, J., Campbell, N. and Swanson, D., 1980, Stratigraphy and structure of the Yakima Indian Reservation with emphasis on the Columbia River Basalt Group: U.S. Geological Survey open-file report $80-200,76 \mathrm{p}$.

Blatt, Middleton and Murray, 1980, Origin of Sedimentary Rocks: Englewood Cliffs, New Jersey, Prentice-Hall, Inc., $782 \mathrm{p}$.

Bretz, J.H., Smith, H.T.U. and Neff, G.E., 1956, Channeled Scablands of Washington: new data and interpretations: Geological Society of America Bulletin, v. 67, pp.9571049 .

Brown, G., 1961, The X-ray Identification and Crystal Structures of Clay Minerals: Norwich, England, Jarrold and Sons Ltd., $544 \mathrm{p}$.

Carroll, D., 1970a, Clay minerals: a guide to their x-ray identification: Geological Society of America Special Paper $126,80 \mathrm{p}$. 
Carroll, D., 1970b, Rock Weathering: New York, Plenum Press, $203 \mathrm{p}$.

Chesworth, W. , 1975A, Soil minerals in the system $\mathrm{Al}_{2} \mathrm{O}_{3}-$ $\mathrm{SiO}_{2}-\mathrm{H}_{2} \mathrm{O}$ : phase equilibrium model: Clays and Clay Minerals, v. 23, pp. 55-60.

Chesworth, W., 1975B, The system $\mathrm{SiO}_{2}-\mathrm{AlOOH}-\mathrm{Fe}_{2} \mathrm{O}_{3}-\mathrm{H}_{2} \mathrm{O}$ and the kaolinitic stage of the goethite facies: Clays and Clay Minerals, v. 23, pp. 389-392.

Chesworth, W., and Dejou, J., 1980, Are considerations of mineralogical equilibrium relevant to pedology: evidence from a weathered granite in central France: Soil Science, v. 130, pp. 290-292.

Corcoran, R.E., and Libbey, F.W., 1956, Ferruginous bauxite deposits in the Salem Hills, Marion County, Oregon: Oregon Department of Geology and Mineral Industries Bulletin, no. $46,53 \mathrm{p}$.

CRC Handbook of Chemistry and Physics, 1974: Cleveland, Ohio, Chemical Rubber Company, 2279 p.

Davis, J.C., 1973, Statistics and Data Analysis in Geology: New York, John Wiley and Sons, $550 \mathrm{p}$.

Degens, E.T., 1965, Geochemistry of Sediments: a brief survey: Englewood, New Jersey, Prentice-Hall Inc., 342 p.

Dennen, W.H. and Norton, H.A., 1977, Geology and geochemistry of bauxite deposits in the lower Amazon Basin: Economic Geology, v. 72, pp. 82-87.

Dicken, S.N., 1965, Oregon Geography: Ann Arbor, Michigan, Edwards Brothers, Inc. 147 p.

Dickerson, R.E., Gray, H.B. and Haight, G.P., Jr., 1974, Chemical Principles, Second Edition: Menlo Park, Ca., W.A. Benjamin, Inc., 871 p.

Gabor, R.K., 1981, The influence of halloysite content on the shear strength of kaolinite: Portland, Oregon, unpublished thesis, M.S., Portland State University.

Gardner, L.R., 1970, A chemical model for the origin of gibbsite from kaolinite: American Mineralogist, v. 55, pp. 1380-1389. 
Glenn, J.L., 1965, Late Quaternary sedimentation and geologic history of the north Willamette Valley, Oregon, Corvallis, Oregon, unpublished dissertation, PhD., Oregon State University.

Goldschmidt, V.M., 1937, The principles of distribution of chemical elements in minerals and rocks: Chemical Society of London Journal, 1937, pt. 1, pp. 655673 .

Gordon, M., Jr., Tracey, J.I., Jr. and Ellis, M.W., 1958, Geology of the Arksansas bauxite region: U.S. Geological Survey Professional Paper, no. 299, 268 p.

Grubb, P.L.C., 1979, Genesis of bauxite deposits in the lower Amazon Basin and Guianas coastal plain: Economic Geology, v. 74, pp. 735-750.

Haas, N., 1983, A geophysical study of the north Scappoose Crrek-Alder Creek-Clatskanie River lineament, along then trend of the Portland Hills fault, Columbia County, Oregon: Portland, Oregon, unpublished thesis, M.S., Portland State University.

Harder, E.C., 1949, Stratigraphy and origin of bauxite deposits: Geological Society of America Bulletin, v. 60, pp. 887-907.

Helling, C.S. and Turner, B.C., 1968, Pesticide mobility: determination by soil thin layer chromatography: Science, v. 162, pp. 562-563.

Helling, CS., 1971, Pesticide mobility in soils: I. Parameters of thin layer chromaotgraphy: Soil Society of America Proceedings, v. 35, pp.732-737.

Heslop, R.B. and Robinson, P.L., 1967, Inorganic Chemistry, Third Edition: New York, Elsevier, 774 p.

Hoffman, C.W., 1981, A stratigraphic and geochemical investigation of ferruginous bauxite deposits in the Salem Hills, Marion County, Oregon: Portland, Oregon, unpublished thesis, M.S., Portland State University.

Hoffman, C.W. and Cummings, M.L., 1982, Ferruginous bauxite deposits and Columbia River Basalt stratigraphy, Salem Hills, Oregon (abs.): Proceedings of the Oregon Academy of Science, v. 18, pp.97. 
Hook, J.W., 1976, Ferruginous bauxite deposits of the Pacific Northwest: Oregon Department of Geology and Mineral Industries Open File Report 0-76-3, $25 \mathrm{p}$.

Hook, J.W., 1982, personal communication.

Hotz, P.E., 1964, Nickeliferous laterites in southwestern Oregon and northwestern California: Economic Geology, v. 59, pp. 355-396.

Jackson, R.L., 1971, Description of the ferruginous bauxite ore profile in Columbia County, Oregon: The Ore Bin, v. 33, pp. 223-229.

Jackson, R.L., 1974, A mineralogical and geochemical study of the ferruginous bauxite deposits in Columbia County, Oregon and Wahkiakum County, Washington: Portland, Oregon, unpublished thesis, M.S., Portland State University.

Keeler, W.D.,1979, Bauxitization of syenite and diabase illustrated in scanning electron micrographs: Economic Geology, v. 74, pp.116-124.

Kelty, K.B., 1981, Stratigraphy, lithofacies and environment of deposition of the Scappoose Formation in central Columbia County, Oregon: Portland, Oregon, unpublished thesis, M.S., Portland State University.

Lackie, J.O. and James, R.O., 1974, Control mechanisms for trace metals in natural waters: in Rubin, A.J. (ed.), Aqueous-Environmental Chemistry of Metals: Ann Arbor, Michigan, Ann Arbor Science Publishers, Inc., pp.1-76.

Lentz, R.T., 1977, The petrology and stratigraphy of the Portland Hills Silt: Portland, Oregon, unpublished thesis, M.S., Portland State University.

Lentz, R.T., 1981, The petrology and stratigraphy of the Portland Hills Silt - a Pacific Northwest loess: Oregon Geology, v. 43, pp. 3-10.

Libbey, F.W., Lowry, W.D. and Mason, R.S., 1945, Ferruginous bauxite deposits in northwestern oregon: Oregon Department of Geology and Mineral Industries Bulletin, no. $29,93 \mathrm{p}$.

Libbey, F.W., Lowry, W.D. and Mason, R.S., 1946, Ferruginous bauxite deposits in northwestern Oregon: Economic Geology, v. 41, pp. 246-265. 
Livingston, V.E., Jr., 1966, Geology and mineral resources of the Kelso-Cathlamet area, Cowlitz and Wahkiakum Counties, Washington: Washington (State) Division of Mines and Geology Bulletin, no. 54, 110 p.

Mendenhall, w., 1975, Introduction to Probability and Statistics: North Scultate, Massachusetts, Duxbury Press, $460 \mathrm{p}$.

Miller, R.M., 1938, Feasibility of a steel plant in the lower Columbia River area near Portland, Oregon: oregon Department of Geology and Mineral Industries Bulletin, no. 8, $55 \mathrm{p}$.

Moreira-Nordeman, L.M., 1979, Distribution of Uranium in soil profiles of Bahia State, Brazil: Soil Science, v. 127, pp. 275-280.

Nishita, H., Hamilton, M, and Steen, A.J., 1978, Extractability of $238 \mathrm{Pu}$ and $242 \mathrm{Cm}$ from a contaminated soil as a function of $\mathrm{pH}$ and certain soil components: $\mathrm{HNO}_{3}-\mathrm{NaOH}$ system: Soil Science of America Journal, v. 42, pp. 51-56.

Owen, D.B., 1962, Handbook of Statistical Tables: London, Pergamon Press, 580 p.

Patterson, S.H., 1971, Investigations of ferruginous bauxite and other mineral resources on Kauai and a reconnaissance of ferruginous bauxite deposits on Maui, Hawaii: U.S. Geological Survey Professional Paper, no. 656, 74 p.

Peterson, U., 1971, Laterite and bauxite formation: Economic Geology, v. 66, pp.1070-1071.

Sherman, D.G., 1949, Factors influencing the development of lateritic soils in the Hawaiian Islands: Pacific Science, v. 3, pp. 307-314.

Snavely, P.D., Jr., Wagner, H.C. and Lander, D.L., 1980, Geologic cross section of the central Oregon contintental margin: Geological Society of America Map and Chart Series, MC-28J, 8 p.

Summaries of climatological data by sections, 1926: Bulletin $W$ Weather Bureau, U.S. Department of Agriculture, Volume I. 
Swanson, D.A., Wright, T.I., Hooper, P.R., and Bentley, R.D., 1979, Revisions in stratigraphic nomenclature of the Columbia River Basalt Group: U.S. Geological Survey Bulletin 1457G, 59 p.

Wilkinson, W.D., Lowry, W.D. and Baldwin, E.M., 1946, Geology of the St. Helens Quadrangle, Oregon: oregon Department of Geology and Mineral Industries Bulletin, No. $31,39 \mathrm{p}$.

Wright, T.L., Grolier, M.J. and Swanson, D.A., 1973, Chemical variation related to the stratigraphy of the Columbia River Basalt: Geological Society of America Bulletin, v. 84, pp. 371-386.

Zeissink, H.E., 1971, Trace element behavior in two nickeliferous laterite profiles: Chemical Geology, v. 7, pp. 25-36. 
APPENDIX A

EXPERIMENTAL METHODS

INSTRUMENTAL NEUTRON ACTIVATION ANALYSIS

Chemical analyses for this work were performed using instrumental neutron activation analysis (INAA). Values for the major oxides $\mathrm{Na}_{2} \mathrm{O}, \mathrm{K}_{2} \mathrm{O}$ and $\mathrm{Fe}_{2} \mathrm{O}_{3 t}$ can be determined in addition to a host of trace elements. INAA is a relatively simple and quick means for determination of multiple trace and major element concentrations from a single sample, and is a definite improvement over other techniques, reducing the amount of time spent in sample preparation. INAA involves sealing a weighed sample of material into a polyethylene or fused quartz tube, bombardment of the sample with thermal neutrons to form various radioisotopes and counting the gamma ray decay products of the product radionucleides to determine the amount of parent nucleide originally present in the sample.

For this work INAA was performed in the Neutron Activation Lab in the Department of Geology at Portland State University on powdered samples sealed into polyethylene containers. Methods used in obtaining powdered samples of fresh basalt differed from those used to 
obtain powdered soil and saprolite samples. Fresh basalt samples were obtained from the centers of basaltic corestones or from samples of basalt obtained from outcrops. The outer weathered portions of the samples were broken off using a 24 ounce Estwing rock hammer. About 20 grams of rock was then chipped from the inner, relatively unweathered, portions of the rock and ground to -20 mesh using a hard steel mortar and pestle. Previous test of the mortar and pestle suggest that contamination of samples is negligible (M.H. Beeson, personal communication, 1982). The 20 grams of -20 mesh powder was stored in glass vials until all samples were crushed. Then each sample was poured out into a conical pile on a piece of weighing paper and the pile was split into two equal portions along a vertical plane through the center of the pile using a steel spatula. One half of the original pile was then formed into a conical pile and the process was repeated until an approximately 1 gram sample was obtained. This sample was placed into a small polyethylene vial which had been previously washed in ethanol and scribed with an identifying number. The vials were weighed both before and after addition of the sample and the net sample weight was calculated from this data.

Samples of saprolite and soil were crushed to -2 mesh using a rock hammer where necessary. A representative 
sample of -2 mesh material was then crushed to -20 mesh using a hard steel mortar and pestle. The -20 mesh sample was split, poured into small polyethylene vials and weighed using the methods described above.

The small polyethylene vials containing the powdered samples of basalt, saprolite and soil were loaded into larger vials. Two small vials fit in each large vial, one one top of the other. Two or more weighed vials filled with standards $\mathrm{W}-1, \mathrm{BCR}-1, \mathrm{G}-1$ or $\mathrm{ARHCO}-1$ were included among the samples on the bottom of the large vials, and a like number were included with the samples on the top of the large vials. Samples were irradiated for 1.00 hours in a TRIGA Mark II reactor equipped with a lazy susan at a flux of $1.7 \times 10^{12}$ neutrons $/\left(\mathrm{cm}^{2} \mathrm{sec}\right)$ located at the Reed College Department of Chemistry. The samples were allowed to decay for 4 or 5 days before they were transferred to Portland State University.

The smaller vials containing the individual samples were then removed from the larger vials and each small vial was placed into a fresh, non-radioactive large vial. Gamma-ray decay products were counted as soon after transfer to fresh vials as possible to determine as many elements with short half lives as possible. A single Geli detector hooked to Tracor Northern hardware and software was used. The spectra of the samples were stored and 
later analyzed to yield net counts and error associated with the counting. Table XI shows the energies used to determine the concentrations of each element. High energies were preferred in determining concentrations, but in many cases high energy peaks were unavailable. The absolute concentration of the elements present in each sample was obtained using a computer program designed to compare net counts in the sample, where elemental concentrations were unknown, with net counts of the same energy in the standard, where the elemental concentrations were known. Error was determined for each sample using statistical means. A copy of the computer program used is not included in this work, but is similar to the program used by Hoffman (1981) and other workers.

Samples were counted again after 3 to 5 weeks of decay time. The counting interval was expanded to 3000 seconds to determine the concentrations of the longer lived isotopes. Data was obtained and reduced as for the first count. Certain elements, such as $\mathrm{Fe}_{2} \mathrm{O}_{3 t^{\prime}} \mathrm{Cr}$ and Sc, were detected in both the first and second counts. This allows cross checking of concentrations of these elements. Concentrations obtained on the first and second count were very close in most cases. 
TABLE XI

ENERGIES USED TO DETERMINE

ELEMENTAL CONCENTRATIONS

USING INAA

\section{ELEMENT}

$\mathrm{Na}_{2}{ }^{\mathrm{O}}$

Sm

$\mathrm{Yb}$

Lu

Sc

Th

Co

$\mathrm{Fe}_{2} \mathrm{O}_{3}$

$\mathrm{Ta}$

Tb

Eu

Hf

$\mathrm{Ce}$

Cs

$\mathrm{Ba}$

$\mathrm{Rb}$

$\mathrm{Nd}$

$\mathrm{Zn}$

$\mathrm{Br}$

U

$\mathrm{K}_{2} \mathrm{O}$
FIRST COUNT

1369

$398,487,816,1596$

103.2

282,396

113,208

889,1120

312

1173,1333

1099, 1292

320

*

*

*

*

*

*

*

*

*

*

$554,619,776$

228

1524
SECOND COUNT

*

177,198

889,1120

312

1173,1333

1099,1292

320

67.8

87,299

122,345

133,482

145.7

504,796

216.1

1077

91.1

1115

*

*

All energies are in Kev.

* not detected 


\section{$\mathrm{X}$-RAY DIFFRACTION}

$\mathrm{x}$-ray diffraction was used to determine the presence of clay minerals in soil and saprolite samples obtained from the study area. Samples for x-ray diffraction analysis were first dryed in an oven at $50^{\circ} \mathrm{C}$ then disaggregated and crushed to -20 mesh using a hard steel mortar and pestle. Once crushed, a representative sample of approximately 10 grams was placed in a beaker together with $10 \mathrm{ml}$ of $1 \mathrm{M} \mathrm{NaHCO}_{3}$ solution and $200 \mathrm{ml}$ of $5 \%$ sodium citrate solution. The sample was then heated to $80^{\circ} \mathrm{C}$ and 2 grams of $\mathrm{Na}_{2} \mathrm{~S}_{2} \mathrm{O}_{4}$ was added to reduce $\mathrm{Fe}^{+3}$ present in the sample. The sample remained at $80^{\circ} \mathrm{C}$ for 15 minutes before being poured into a centrifuge flask and centrifuged at high speed to separate the solid and Iiquid. Once the solid matter settled out of suspension, the liquid (carrying $\mathrm{Fe}^{+2}$ ) was discarded. The solid was washed from the centrifuge flask using a $28 \mathrm{Na}_{2} \mathrm{CO}_{3}$ solution for flushing, and the volume of the solid and liquid mixture was brought to $200 \mathrm{ml}$ using distilled water. Four grams of anhydrous $\mathrm{Na}_{2} \mathrm{CO}_{3}$ was added, the mixture was agitated at high speed in a rotary mixer for five minutes, boiled for five minutes in a covered beaker and then centrifuged at high speed to separate the solid and liquid portions. The liquid was then discarded. 
Some of the first analyzed samples were subsequently treated to remove aluminum oxides and hydroxides. After this process, the solid was washed from the centrifuge flask using $200 \mathrm{ml}$ of a very dilute $(0.01 \mathrm{M}) \mathrm{Na}_{2} \mathrm{CO}_{3}$ solution, then agitated with a rotary stirrer, returned to centrifuge flasks and centrifuged at the proper speed and for the proper length of time to leave the -2 micron (clay) size fraction in suspension. The suspension was decanted from the flask and saved. The +2 micron (sand and silt) fraction which settled out was discarded. The -2 micron suspension was dripped onto either a $45 \mathrm{~mm} \times 23 \mathrm{~mm} \times 1 \mathrm{~mm}$ porous ceramic tile lying on a suction aparatus or onto a glass microscope slide. The solution dripped onto porous ceramic tiles was pulled down through the slide by the suction aparatus. This left an oriented sample of clay on the surface of the tile. The glass slides were allowed to air dry and natural sedimentary processes produced an oriented sample. Suspension was added to the slide or tile until the clay layer was easily visible on the surface of the slide or tile. The layer became too thick on some slides and the clay cracked and plucked off the slide surface during drying.

Three slides or tiles were prepared for each sample. One slide was left untreated in a $\mathrm{Na}^{+}$saturated form; one 
slide was treated with dimethylsulfoxide (DMSO), an organic solvent, to determine the presence or absence of metahalloysite; and the final slide was heated to $550^{\circ} \mathrm{C}$ for two hours to help in positive identification of the clay peaks.

Approximately $0.5 \mathrm{~cm}^{3}$ of DMSO was dripped onto the porous tiles to treat the clays with DMSO. Considerable effort was devoted to trying to develop an adequate technique for applying DMSO to clays mounted on glass microscope slides; unfortunately no convenient, workable technique was developed. After all treatments were completed, the slides and tiles were placed in a dessication chamber dryed by layers of $\mathrm{CaCl}_{2}$ placed on the floor of the chamber in petri dishes. X-ray diffraction patterns were produced using a GE XRD-5 set at $40 \mathrm{KV}$ and $18 \mathrm{~mA}$ with a $1 \mathrm{~mm}$ solar slit, a $\mathrm{Nifilter}$ and a $0.1 \mathrm{~mm}$ detector slit. Samples were run at a rate of $2^{\circ} 2 \theta /$ minute. Sample diffractograms are shown in Figure 12.

The three $x$-ray diffraction patterns were used to determine the identity of the peaks obtained. Interpretation of the clay mineralogy of the samples was also constrained by past chemical analyses of similar materials (Libbey and others, 1945, Corcoran and Libbey, 1956, Jackson, 1974, Hoffman, 1981). It was not deemed necessary, for example, to conduct tests to differentiate 
serpentine from kandite clays because MgO is not present in sufficient quantities to produce serpentine. 


\author{
APPENDIX B
}

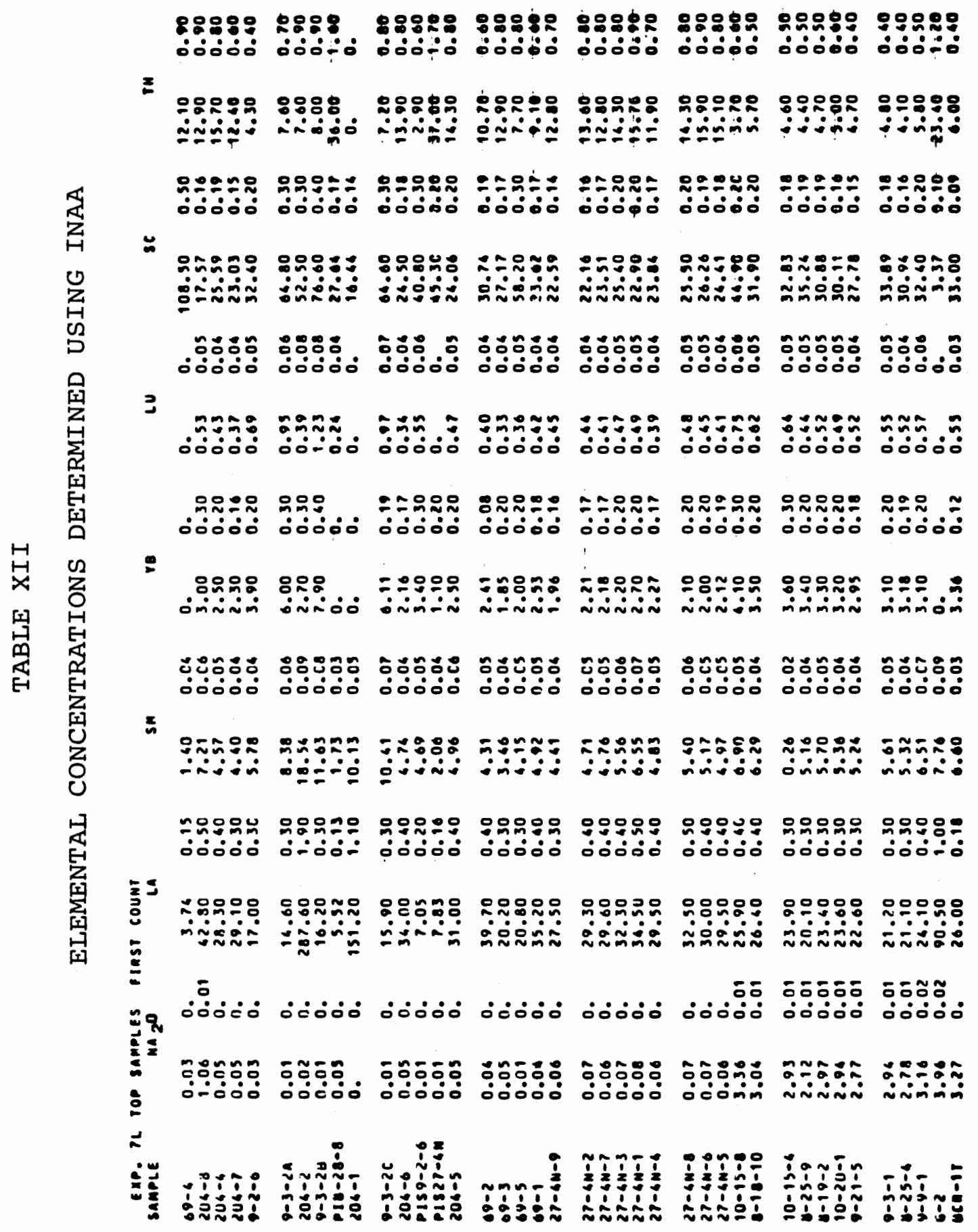




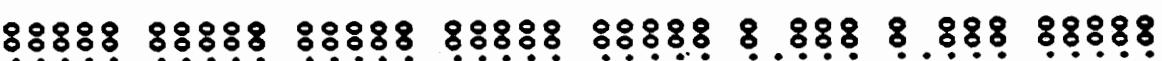

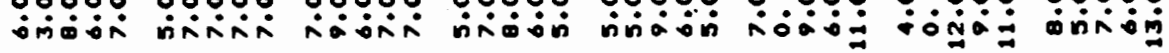

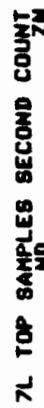

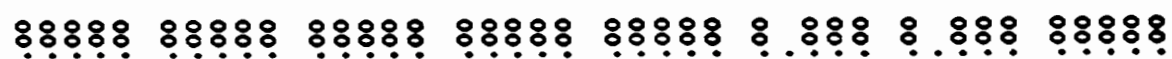

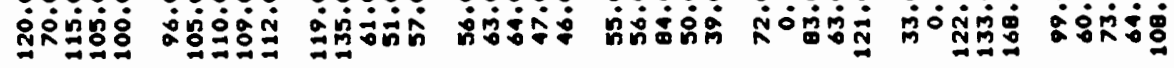

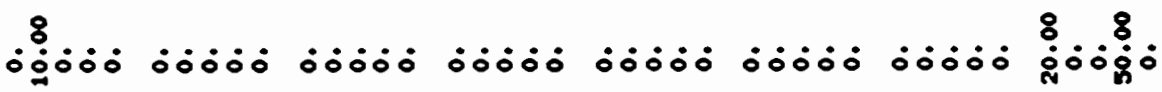
整

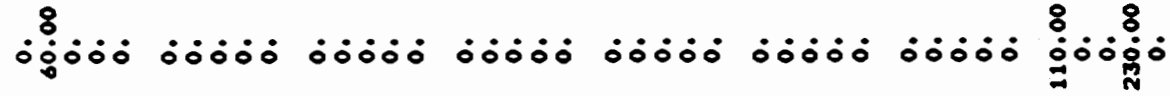

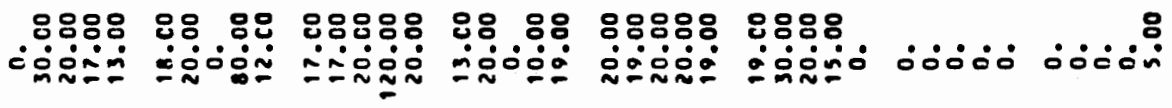
$\Xi$

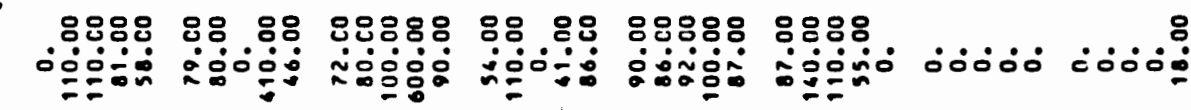

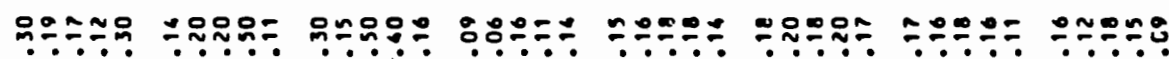

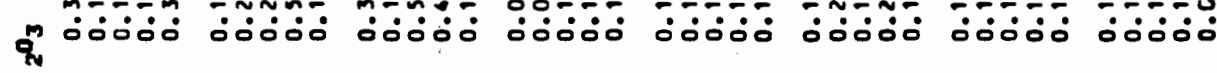

5
$\vdots$
$\vdots$
$\vdots$
$\vdots$

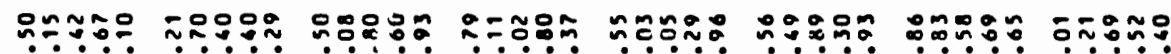
幽道

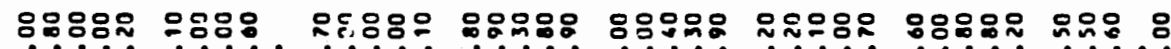

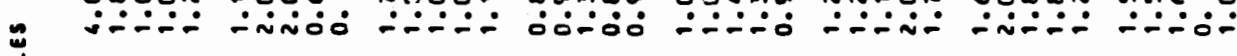
a

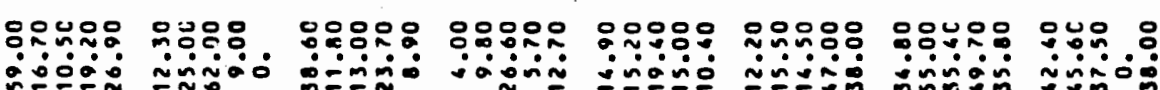

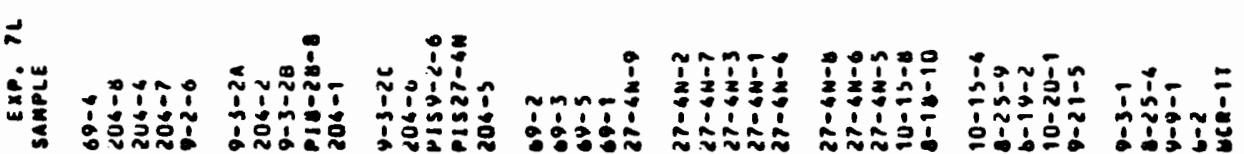




\begin{tabular}{|c|c|c|c|c|c|c|c|c|}
\hline & 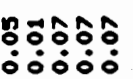 & 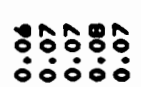 & 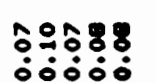 & 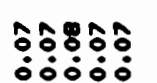 & 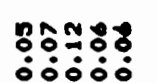 & 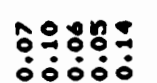 & 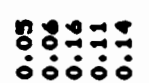 & هُ \\
\hline & 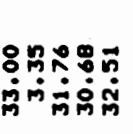 & 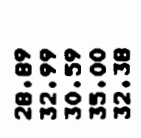 & 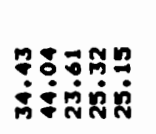 & 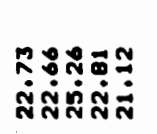 & 華 & 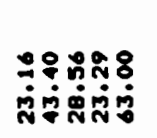 & 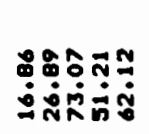 & 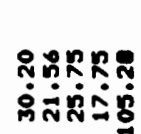 \\
\hline & 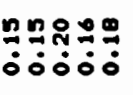 & 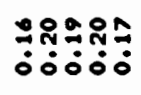 & 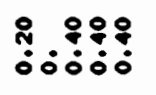 & 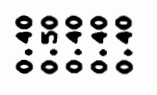 & 㝵象早? & 过道: & $\therefore 000$ & 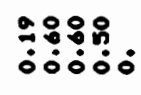 \\
\hline & 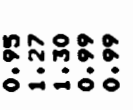 & 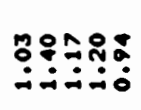 & 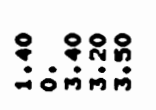 & 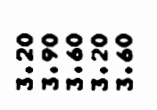 & 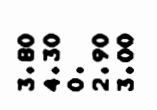 & 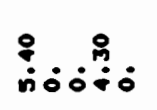 & $\therefore 0000$ & 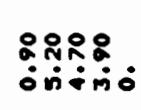 \\
\hline & 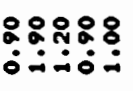 & 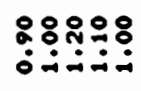 & نִ & 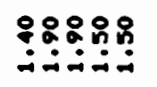 & 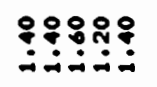 & 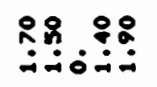 & 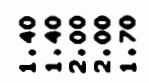 & 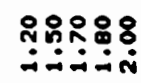 \\
\hline & 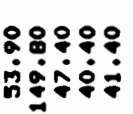 & 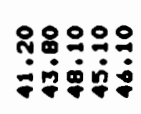 & 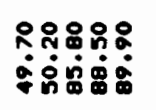 & 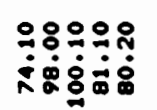 & 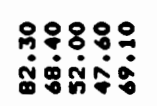 & 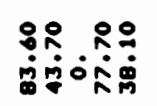 & 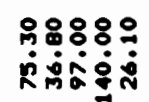 & 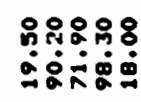 \\
\hline & 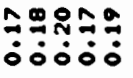 & 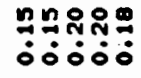 & 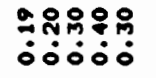 & 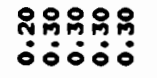 & 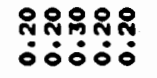 & 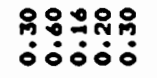 & 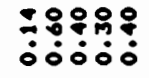 & 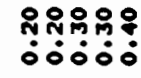 \\
\hline & 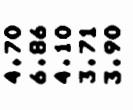 & 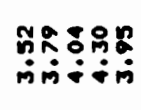 & 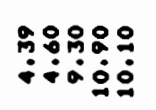 & 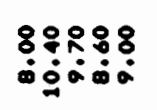 & 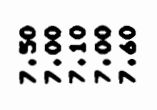 & 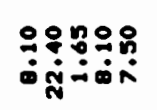 & 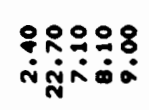 & 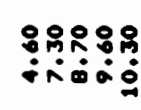 \\
\hline & 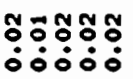 & 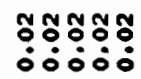 & 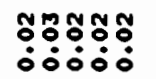 & 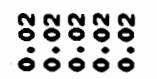 & 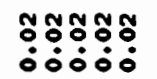 & 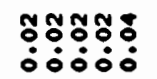 & 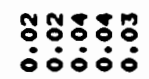 & 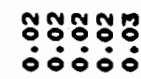 \\
\hline & 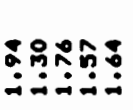 & 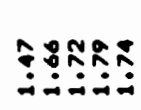 & 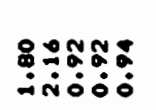 & 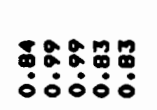 & 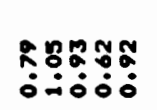 & 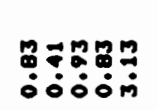 & 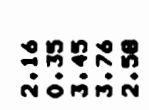 & 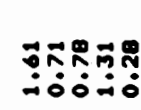 \\
\hline & 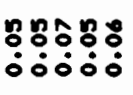 & فํ: & 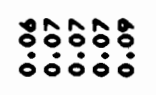 & 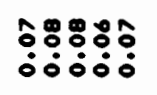 & 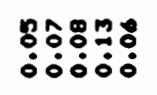 & 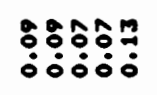 & 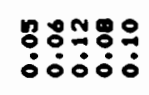 & إذ \\
\hline & 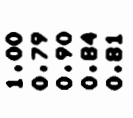 & 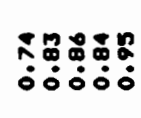 & 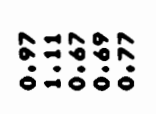 & 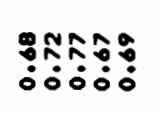 & 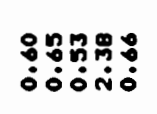 & 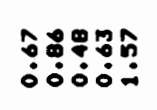 & 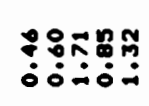 & 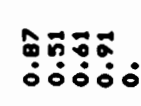 \\
\hline & 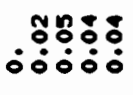 & فำ & : & 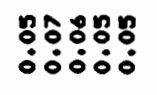 & 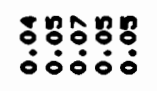 & نั: & 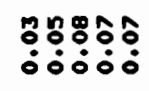 & 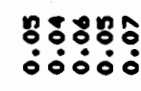 \\
\hline & 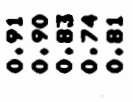 & 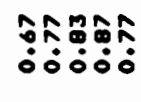 & 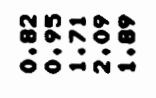 & 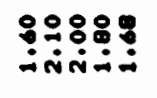 & ดุ & 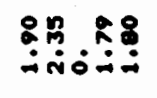 & هُ & 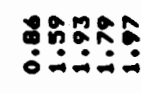 \\
\hline & 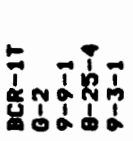 & & I. & 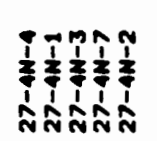 & & 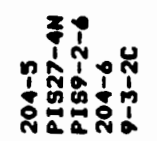 & 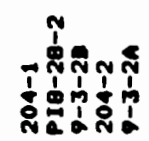 & ํํำ \\
\hline
\end{tabular}


$\$ 88$

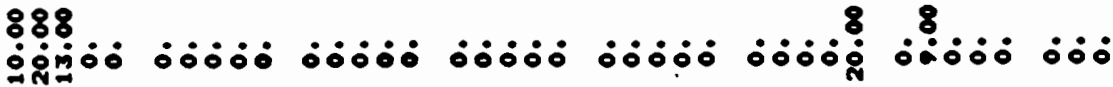

8

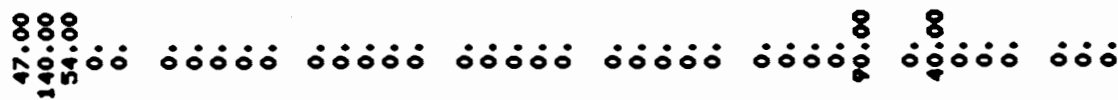

$88: 8: 8: 88$

\&

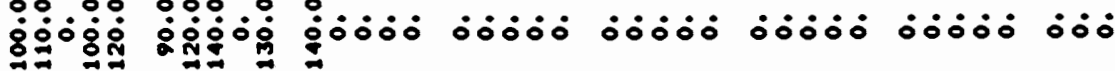

88.88888 .88

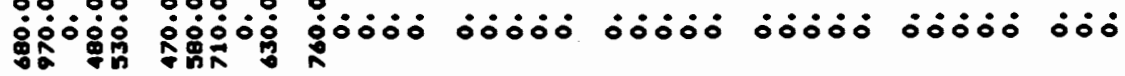

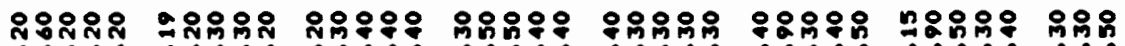

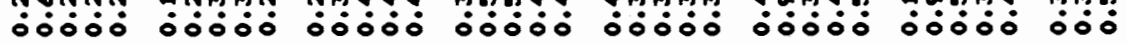

I

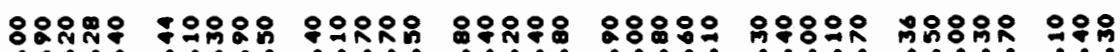

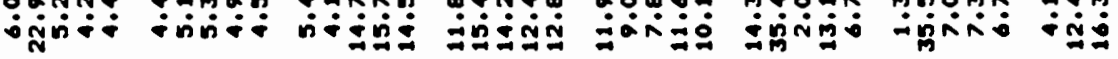

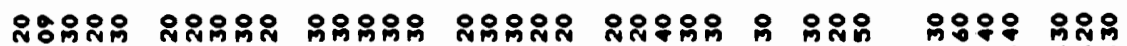

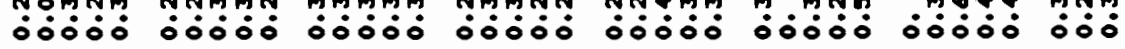

$>$

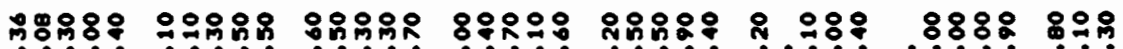

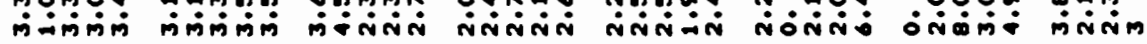

$888.8 \quad 88 \quad 88888 \quad 88888 \quad 88 \quad 88 \quad 88888 \quad 88 \quad 88 \quad 8808$

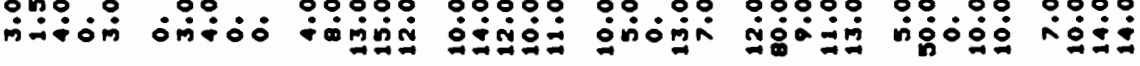

8

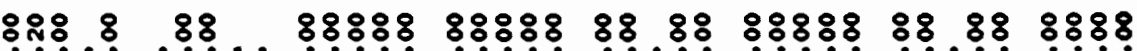

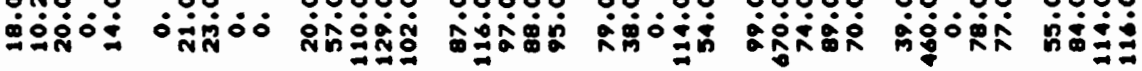

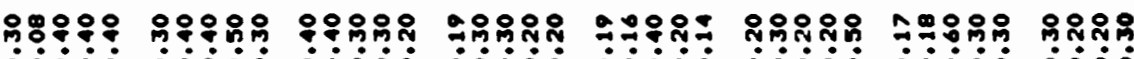

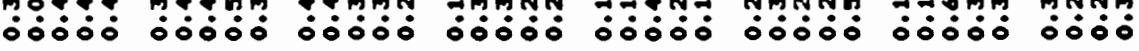

氮

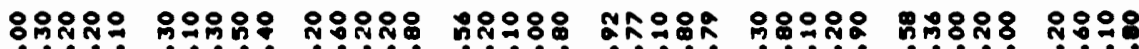

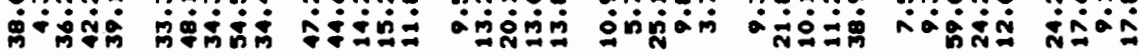

象

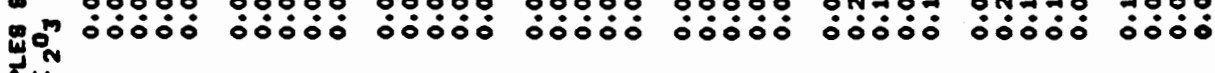

䨔

8

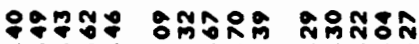

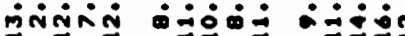

R

离萦

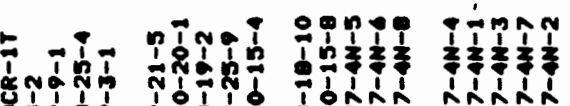

ñ̂ñ̂́n

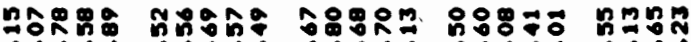

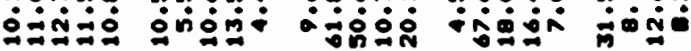

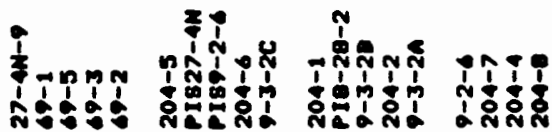




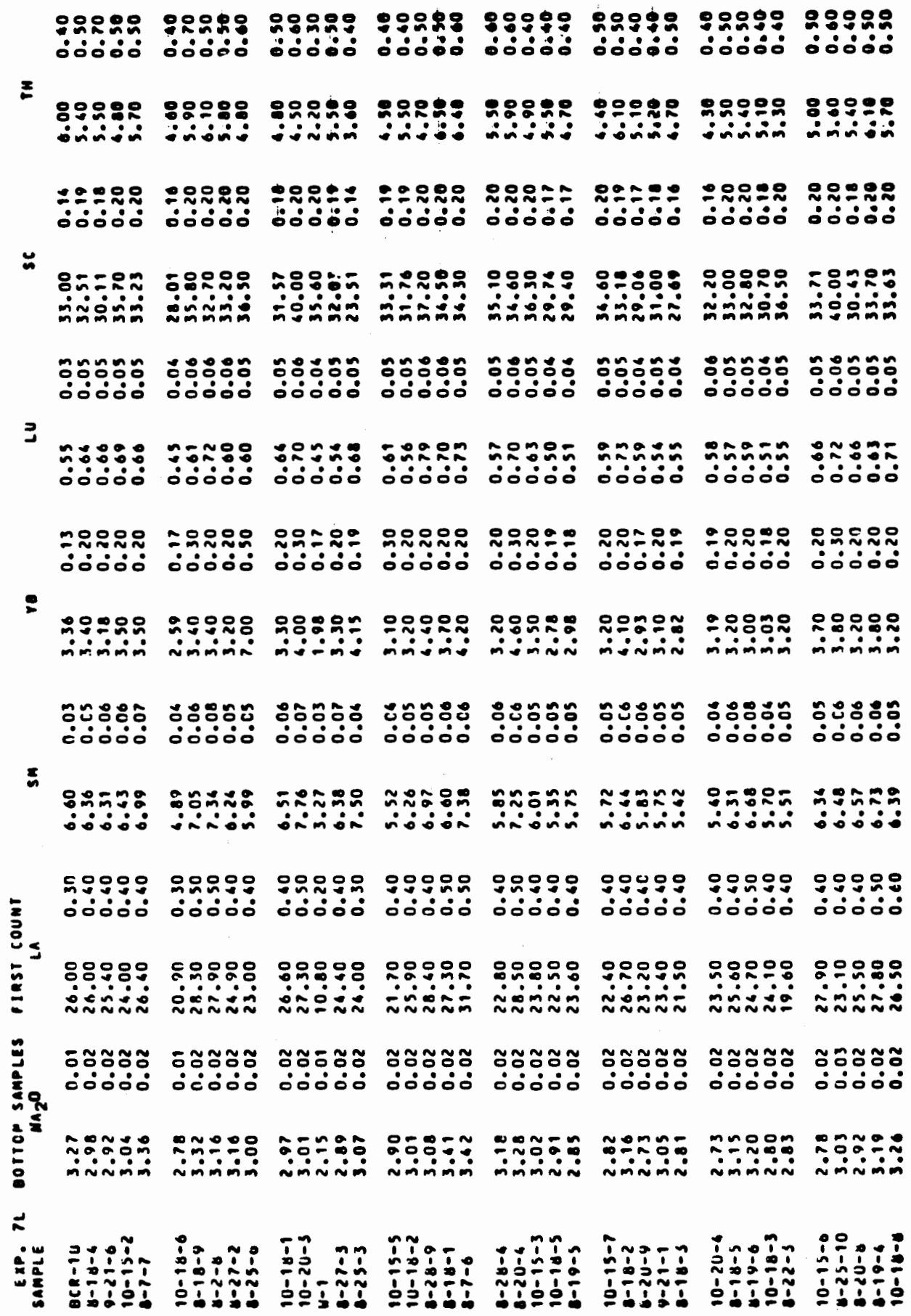



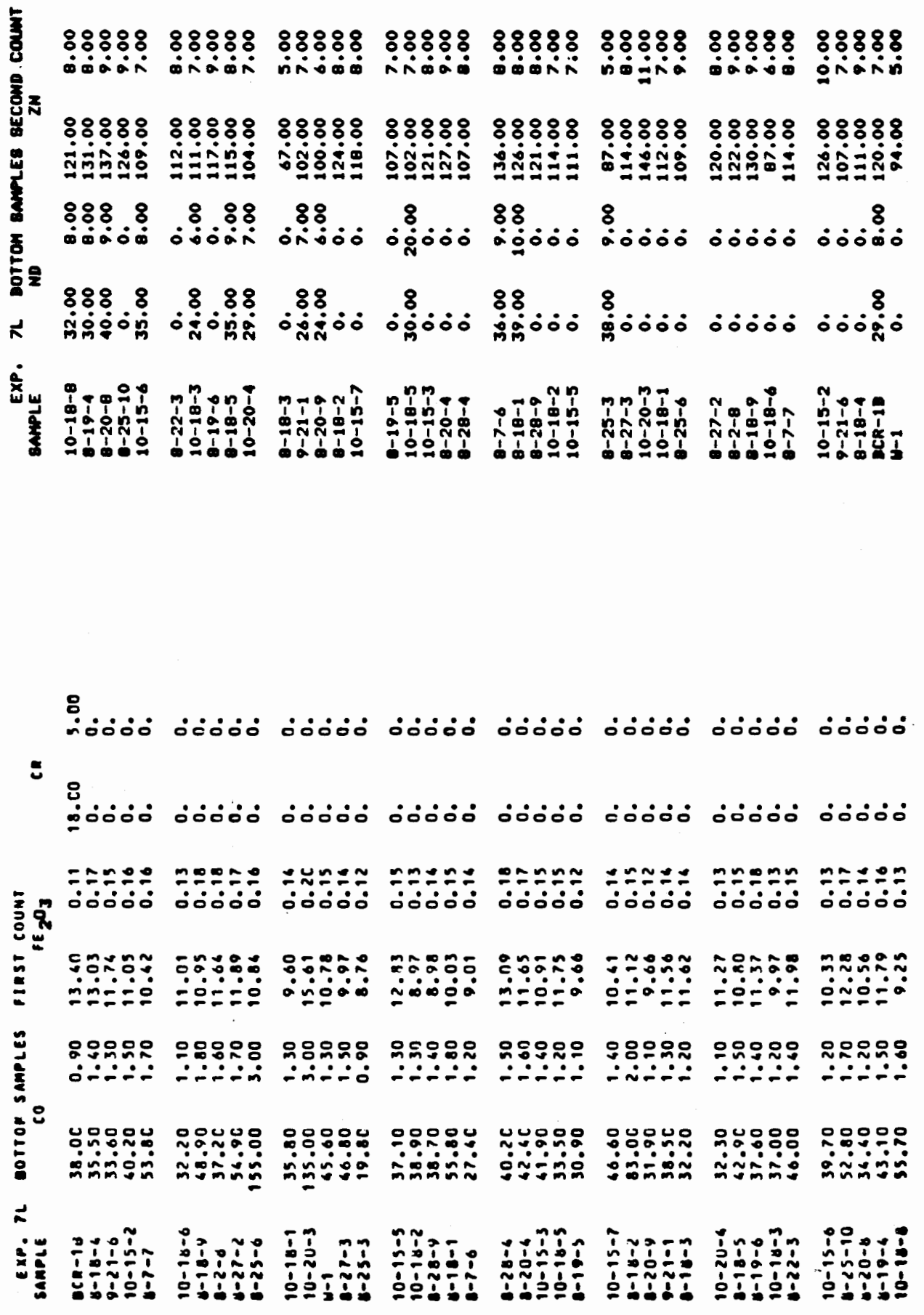


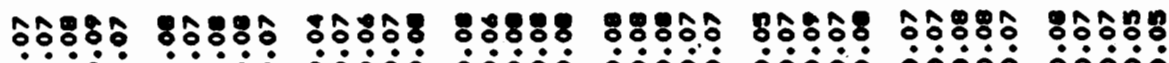

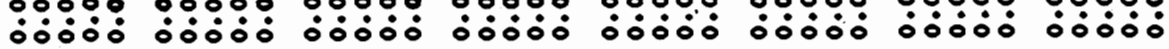 y

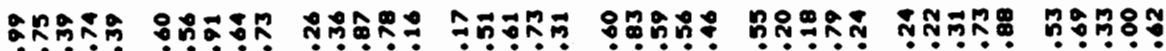

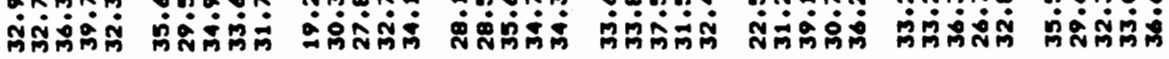

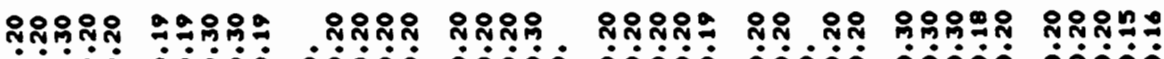 \\ 里

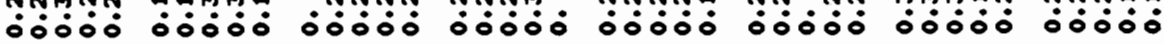

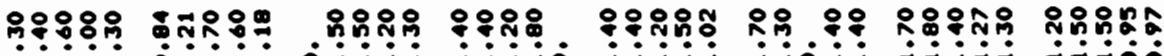

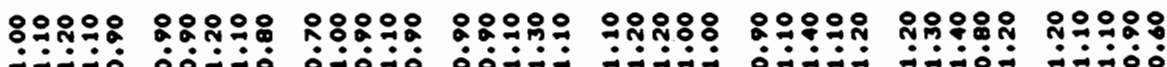 \\ ษ

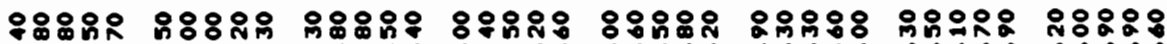

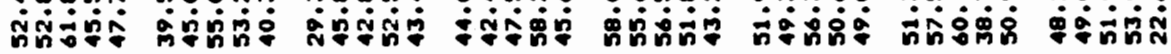

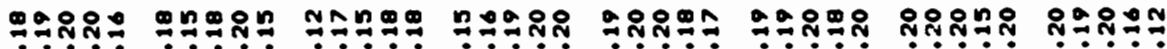

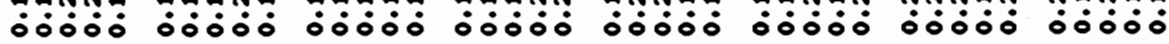 \\ 早

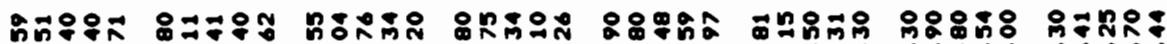

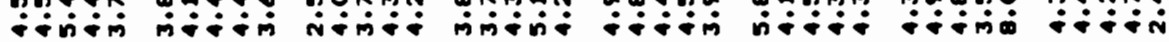

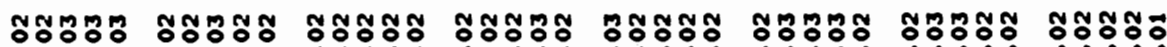

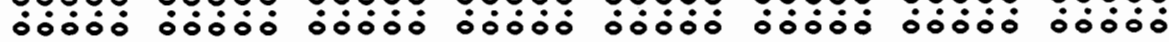 \\ בี

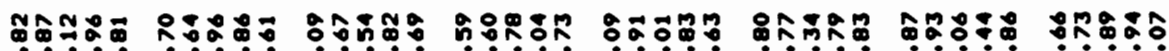

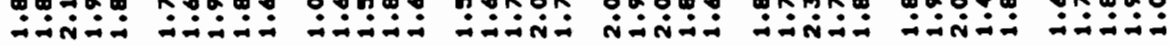 \\ 通

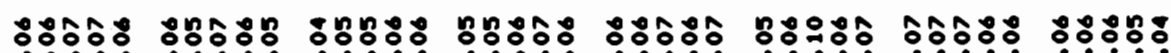

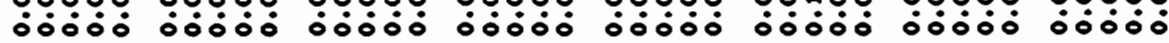 \\ 㿤

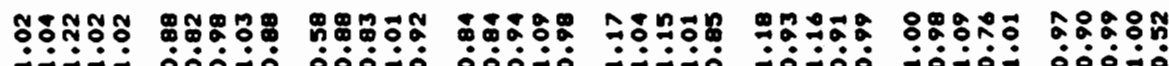

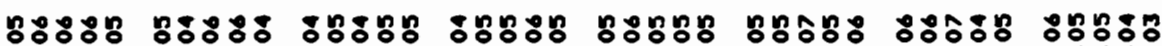

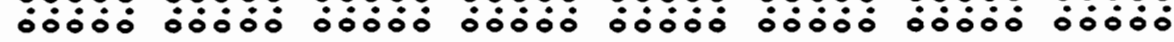

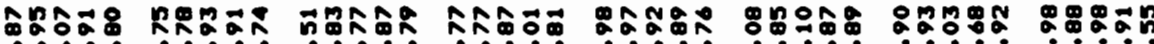

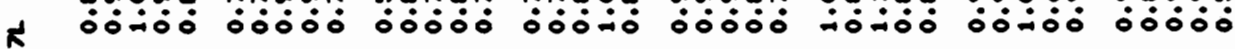




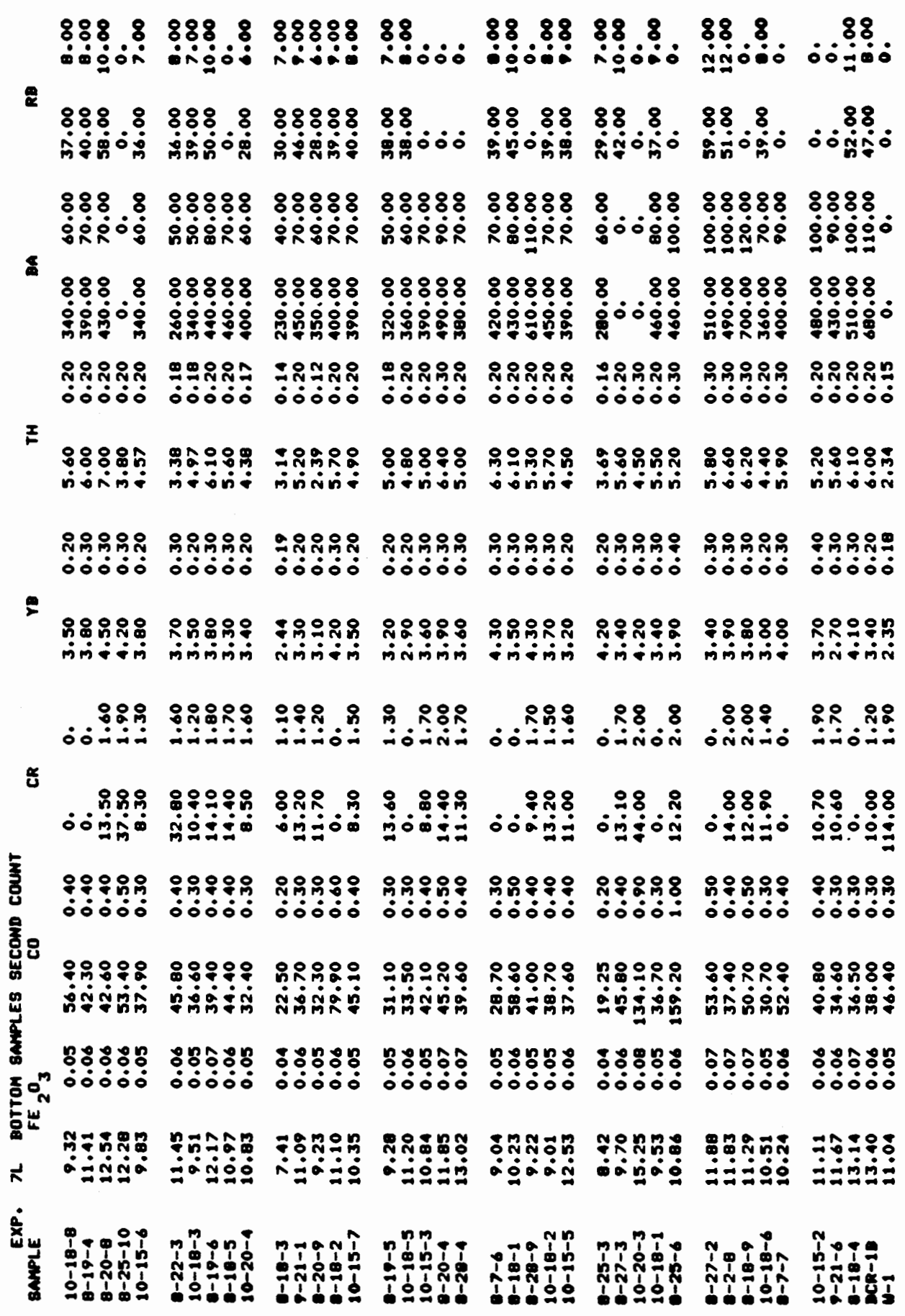




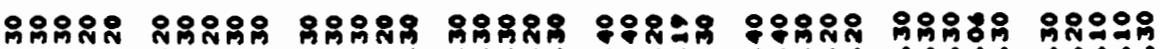

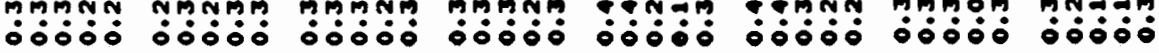

\&

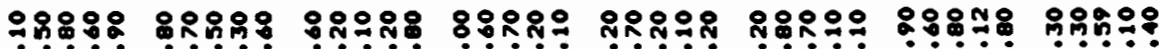

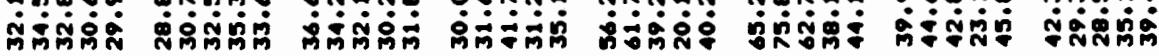

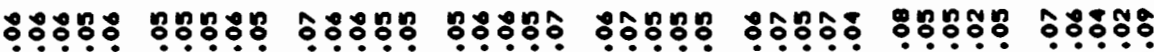

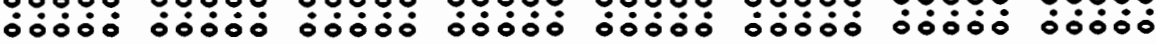

奂的罂

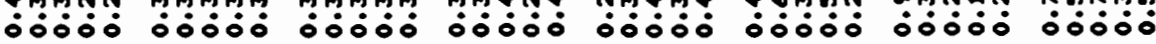

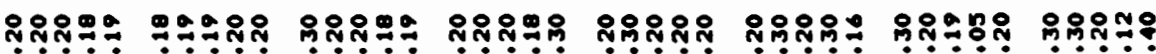

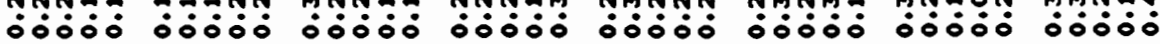

;

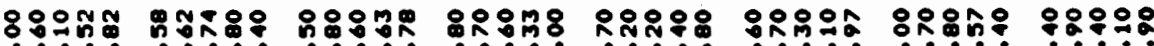

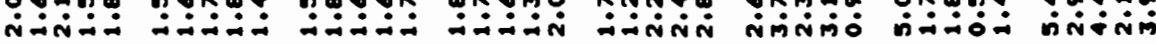

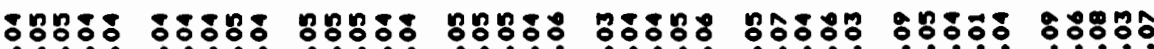

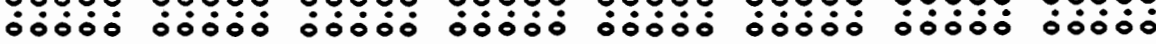

줗

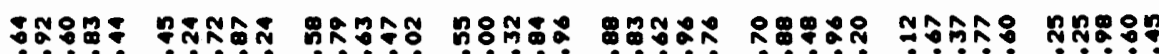

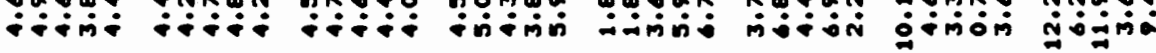

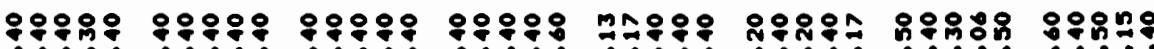

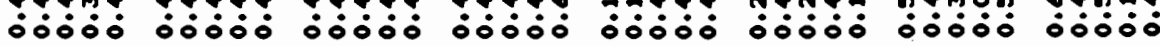

5

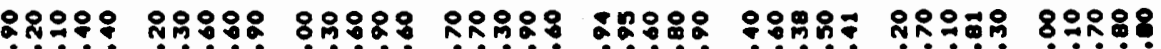

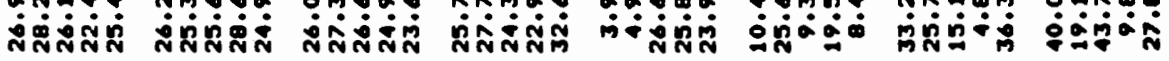

\begin{tabular}{|c|c|c|c|c|c|c|c|}
\hline 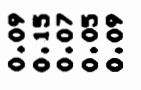 & 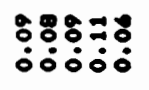 & 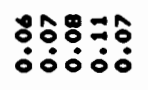 & 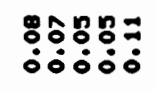 & 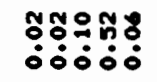 & فํ: & 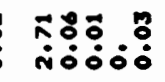 & 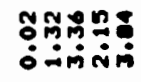 \\
\hline 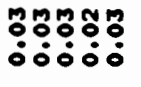 & 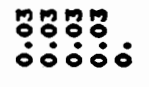 & 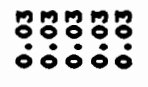 & 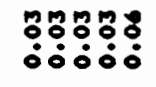 & 苂: & 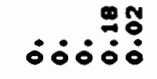 & : & 送 \\
\hline 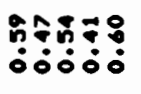 & 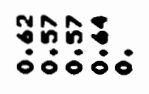 & 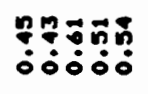 & 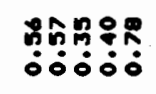 & 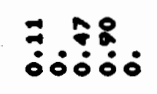 & 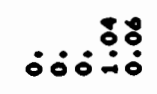 & ڤั & 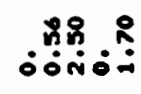 \\
\hline 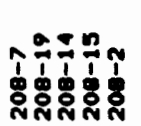 & 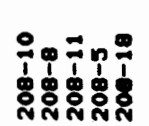 & 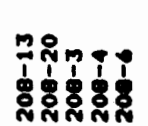 & 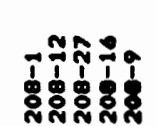 & dond & & 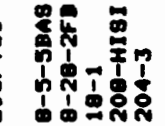 & \\
\hline
\end{tabular}




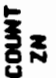

普

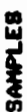

点

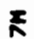

永考

กำำ

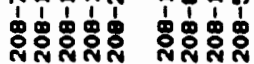

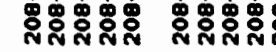

이요 900098008990000

ด0000 00000 00000

$\Rightarrow$

옹ํํำ

inimini

8용ํㅇㅇㅛ

inं

유유요

ำำำ

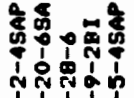

वूक्ष

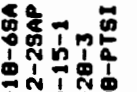

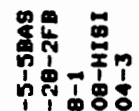

우요요요

๓่ํํㅇำ
\&888 888 \& 88888

$888: \quad 888888888$ în

$88 \quad 8888$ no000 ioni.

88:8: 8:8:8 88888 8::8:

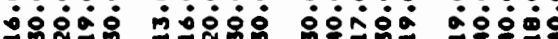

兴

$88888 \quad 88888 \quad 88888 \quad 88888$

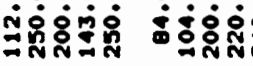

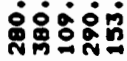

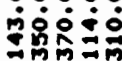

8.88

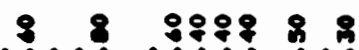

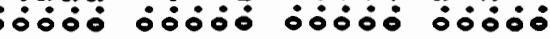

$88888 \quad 88888 \quad 8: 888$

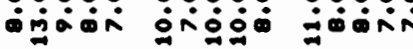

$888: 8$

ตㅁ.

8888

8

$88888 \quad 88888 \quad 88888 \quad 88888$

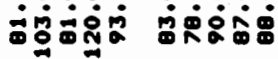

¿்욧

ஸिं:

$88: 8$

inin:

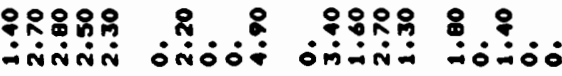

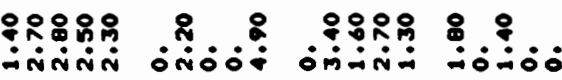

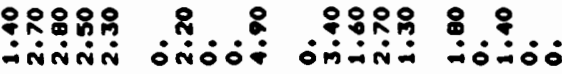

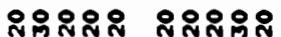

융유유

우웅요뭉

웅욤요요 용

88

8

8.88

0000유ํ $\boldsymbol{o n}^{m}$ นึ

荧。

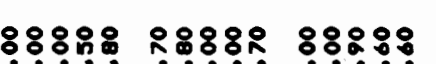

○ं0:0:

¿0:0:

88

88

8

888

8

OOOOO 00000 DOOOO

우웅요

우8:웅

28809

우용ㅇㅇ응

88

888

888

$\therefore 0008$

inia:

ต

ninis:-

mi: $\dot{0} \dot{0}$

inisio:

운유요

888

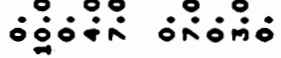

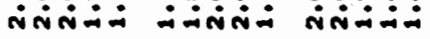

ஃஃ\%8

$88 \div 8 \%$

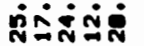

iุ.

8 융ㅇㅇ8

inition

लंĩin:

$8: 88:$

8ํํ욤ำ

ํำㅎํำ

융요 웅요

8유용

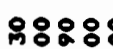

88용

ininivio

요용

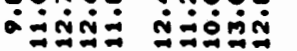

iñ

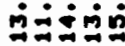

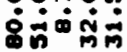

8:8:우

웄유요8

iño:

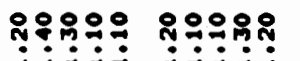

웅용ㅇㅇ음

우윰유융

88098

ininis

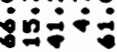

ํำ:88

छั

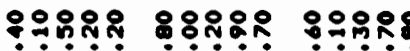

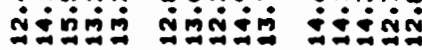

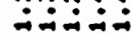

$\div \div \div 9$

우윰ํ요

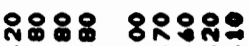

․․․

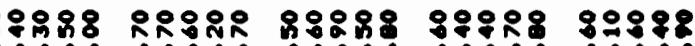

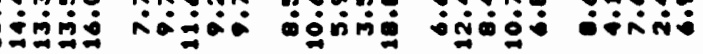

₹

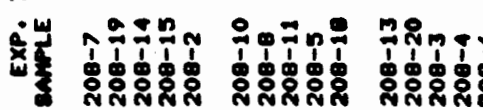

ใด้

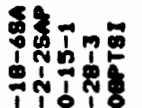

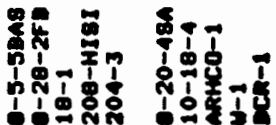




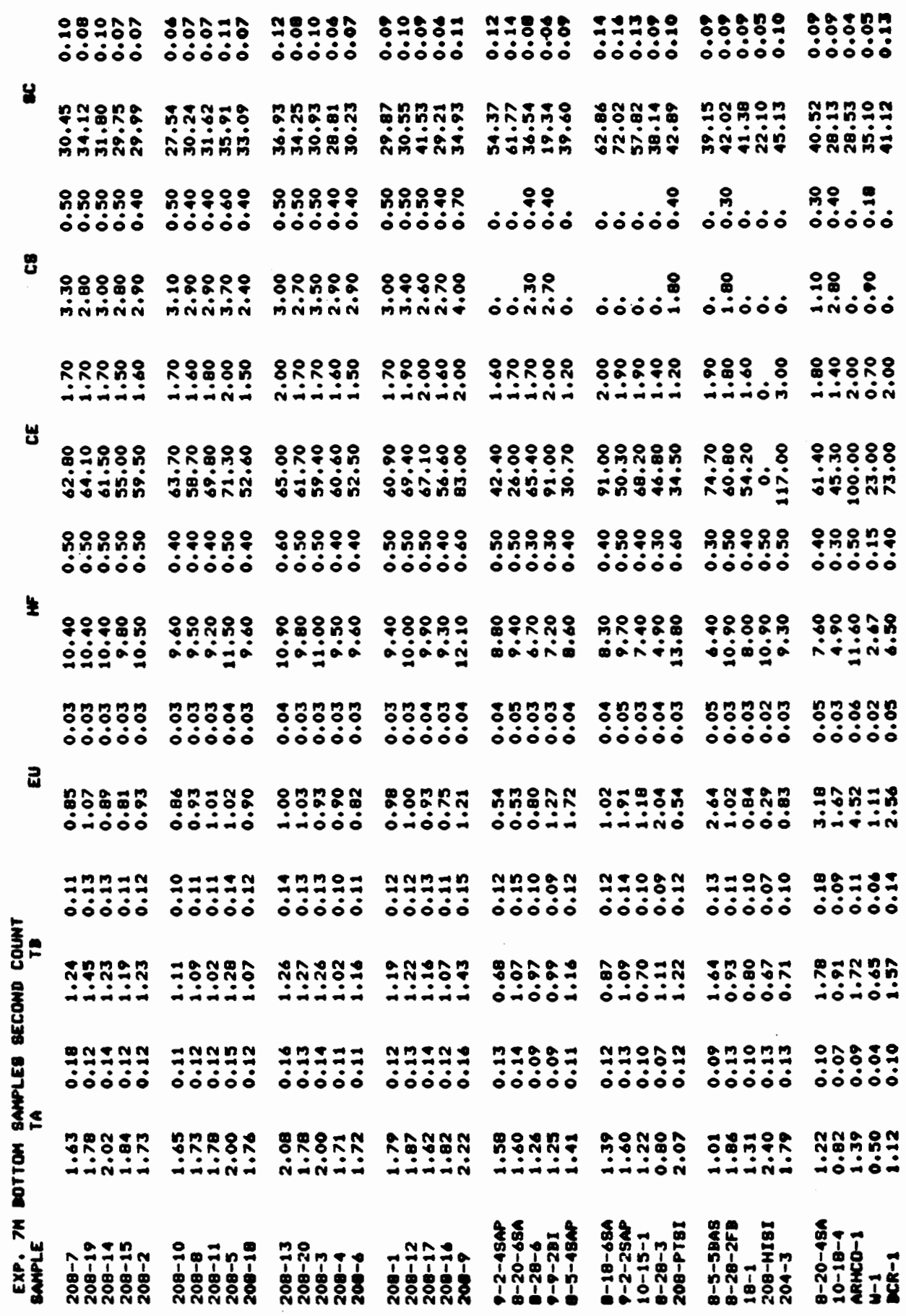




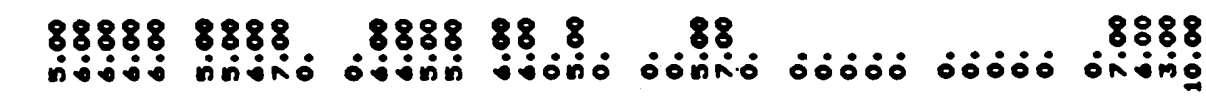

2

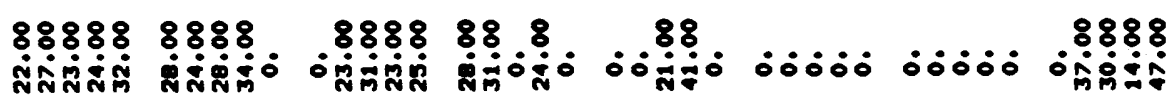

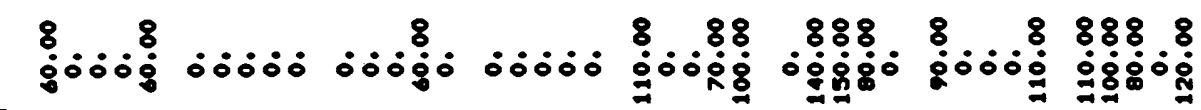

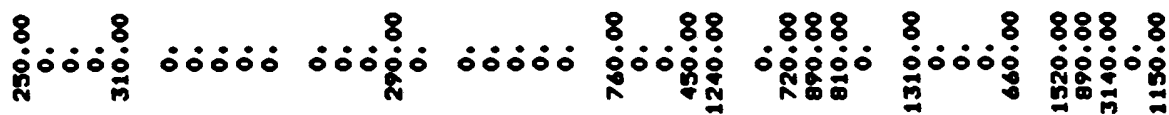

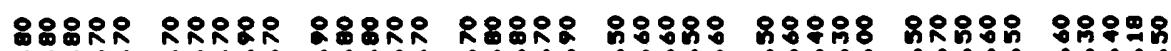

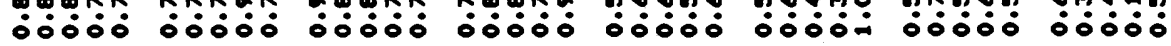

z

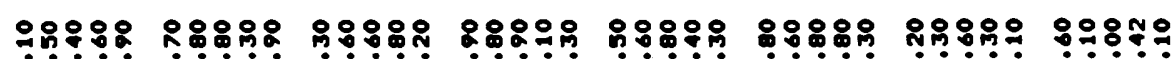

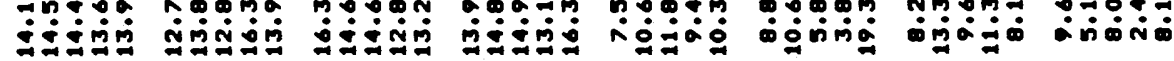

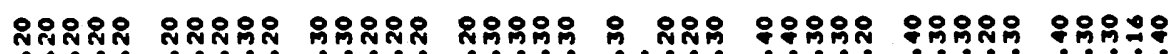

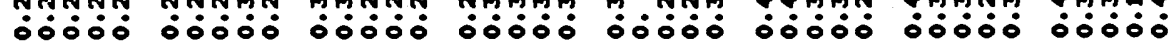

$=$

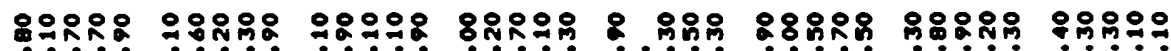
ثنं

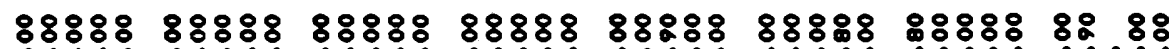

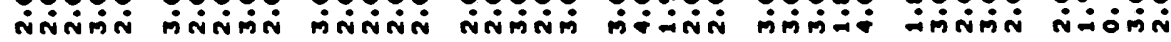

8

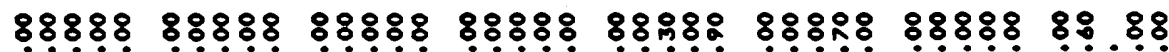

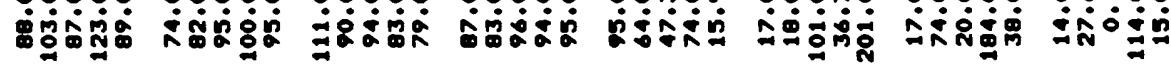

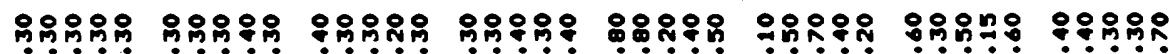

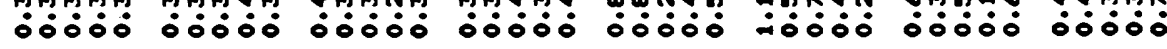

$$
\text { 웅 }
$$

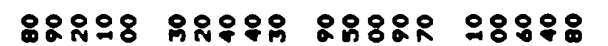

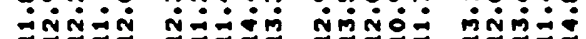

8ㅇํ요

우ํํำ

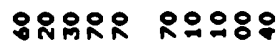

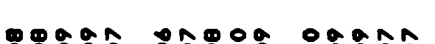

$80 \%=$

๓ิ㇒ี่

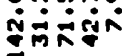

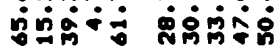

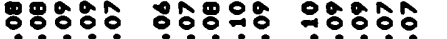

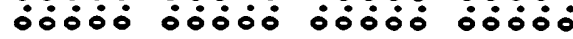

$m+n m o$ 을

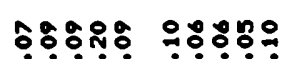

5 manga รถ⿻⿻一𠃋十

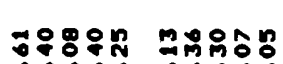
Tำ ining 붐ำ inin:

ำกำ

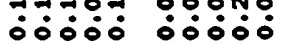
ดำ

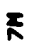

ํำ

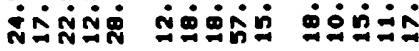

